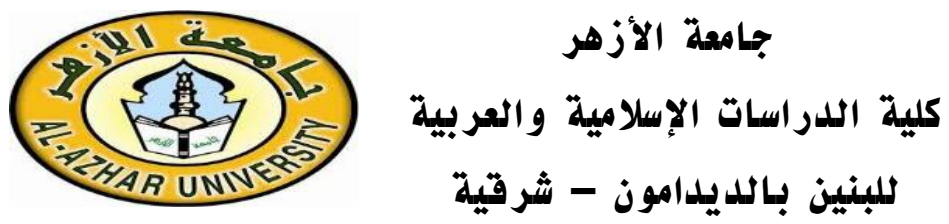

\title{
بلاغة القرآن ووسطيته في معالجة الشقاق بين الزوجين
}

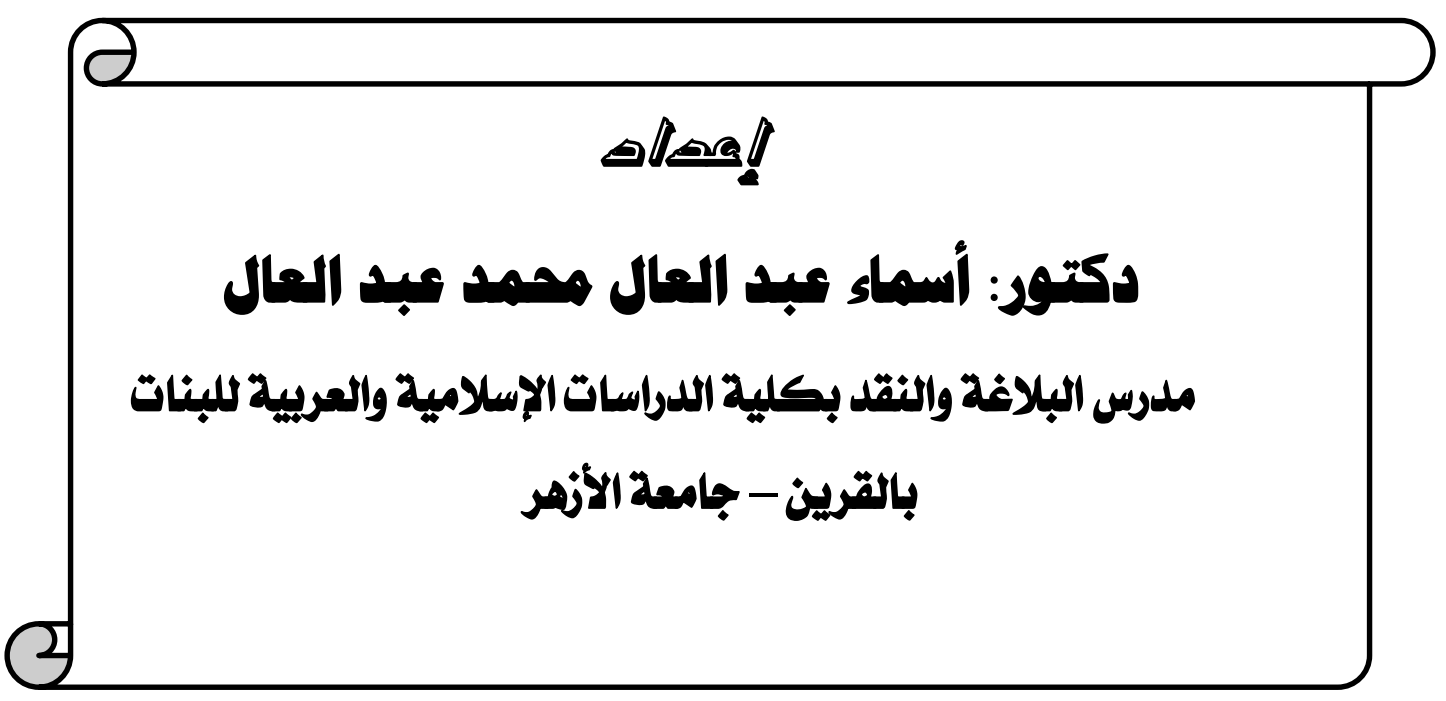

$$
\text { المؤتمر العلمي الدولي الأول }
$$

$$
\text { rer }
$$


- YYYA - 
بلاغة القرآن ووسطيته في معالجة الشقاق بين الزوجين

أسجاء عبد العال محمد عبد العال

قسم البلاغة والنقد - كلية الدراسات الإسلامية والعربية للبنات بالقرين - ميداليدال

جامعة الأزهر - مدينة القرين -جمهورية مصر العربية.

ملخص البحث :

الحمد الله رب العالمين والصلاة والسلام علئ أشرف الثلق وسيد المرسلين.

هذا بحث بعنوان (بلاغة القرآن ووسطيته في معالجة الشقاق بين الزوجين)

وكان من أ سباب اختياره تر سيخ جذور قوية للبلاغة القرآنية في الدرا سات العربية،

وإظهار بلاغة القرآن وو سطيته في مواجهة المشكلات الأسرية ، ومدئ مرونته وصلاحيته في تئي

كل زمان ومكان، مع بيان ما تفردت به الآيات القرآنية التي تعالج الشقاق بين الزوجين من ظواهر وأساليب، التي تظهر دور الشريعة الإسلامية الغراء، وو سطيتها في تنظيم العلاقات بلتهات الزوجية، والبعد عن الشقاق والنشوز .

هذا ، وقد جاء البحث في مقدمة ، وتمهيد ، ومبحثين، وخاتمة ، وفهرس للمصادر والمراجع،

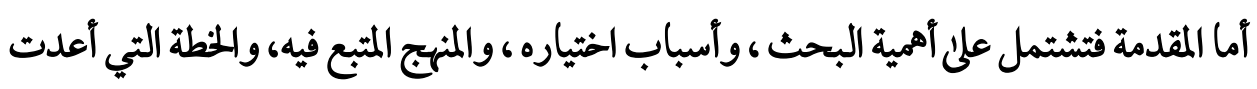
لإنجازه، والتمهيد تضمن الحديث عن بلاغة القرآن، ثم وقفة مع معانى الوسطية ، وبيان

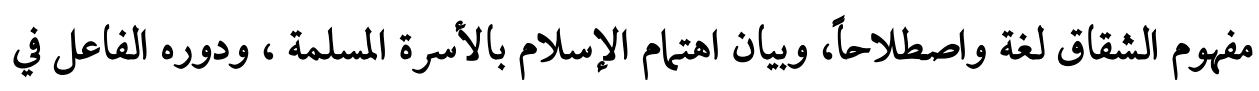
معلجة الشقاق والنشوز، ونبذة عن سورة النساء محل الآيات التي عالجت قضية الشقاق بين

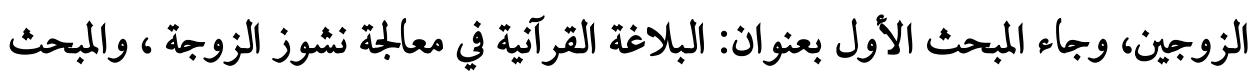
الثاني: البلاغة القرآية في معالجة نشوز الزوج.

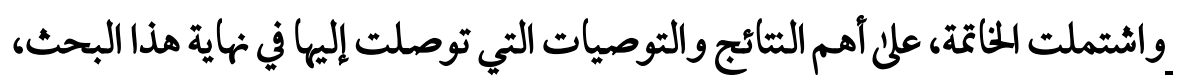

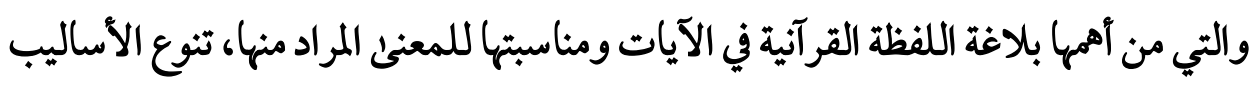
البلاغية في الآيات القرآنية ما بين إيياز وإطناب، وخبر وإنشاء وكل له أسراره التي ذكرت في 
مواضعها، وفي النهاية أوصئ نفي وكل باحث في البلاغة العربية أن يستقى أصول هذا العلم

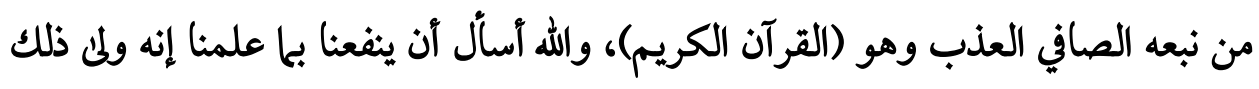
والقادر عليه، والحمد لله رب العالمين. الكلمات المفتاحية: بلاغة - القرآن_وسطية - الشقاق - الزوجين. 
the Eloquence and Modesty of the Qur'an in Deali ng with Discord between Spouse In the Holy Quran, an analytical rhetorical study

Asmaa Abdel Aal Mohammed Abd el Aal

Department of Rhetoric and Criticism - College of

Islamic and Arabic Studies for girl in alqarin

Al-Azhar University - city: alqarin

Country: Arab Republic of Egypt.

Research Summary

Praise be te God the Generous the Benevo leat and tha nks be to God fer'the great bountty $\&$ benevolencer ease an d help me to Study's the shadows of the Qur'an.

My research was entitled( the Eloquence and Modesty of the Qur'an in Dealing with Discord between Spouse).

One of the reasons for its choice was to establish strong roots for Quranic rhetoric in Islamic Studies. and to show the eloquence and moderation of the Qur'an in the face of Contemp·rary problems، which are emerging، and the extent of its flexibility and validity at every place time with an explanation of the uniqueness of the Quranic verse as that deal with Discord between Spouse. in terms of phenomena and methods which show the role of Islamic Sharia and its moderation in rejecting violence and what it ordered to regulate relations Marriage avoidance of discord and disobedience

the Research included: an introductions' a preface، two chapters' a conclusion and general indexes. As for the introduction' it includes the importance of the topic' the reasons fer choosing it the approach fallowed and the plan prepared to achieve it. The preface includes talking about the eloquence of the Qur'an and the explanation of Islam's interest in the Muslim family and is active role in dealing with discord disobedience، then stopping it the meaning of moderation and overview of Sur at al- Nisa 'where the verses that dealt with the iss ue of discord between' spouses. 
The First topic was entitled: Quran. Rhetoric in dealing with husbands insubordination. The Conclusion included the most

important results and recommendations reached at the end of research' the most important of which is the eloquence of the Quranic verses and its relevance to the intended meaning.

In the end، I recommend myself And every researcher of Arabic rhetoric to derive the origins of this Science from c its pure and sweet spring ( the Holy Quran) and Task God to benefit us with what we know that $\mathrm{He}$ is the Guardian of that and He is able to do it - and praise be to God Lord of the worlds

Keywords:( the Eloquence - Modesty- the Qur'an Discord -the Couple) 


\section{|إملدمة}

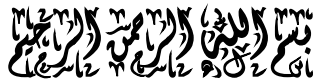

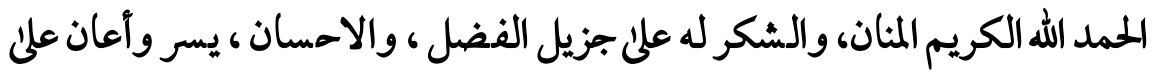

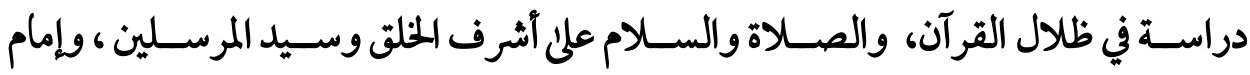

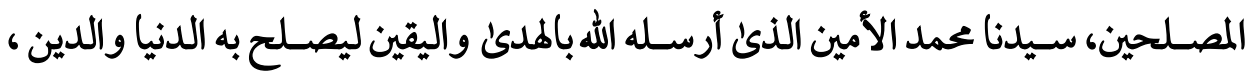
وينشر السلام بالإسلام، ويؤلف بين الأنام بالمحبة والوئام ، عليه أفضل الصلاة والسلام.

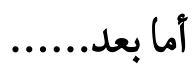

فإن علم البلاغة أحد العلوم التي تخدم القرآن الكريم ؛لأنه يتوصـل بها إلى معرفة أسرار بلاغته، ودلائل إعجازه، وترشدنا إلى مواطن السر من إعجاز كتاب رب العالمين عن

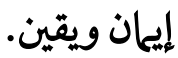
والقرآن الكريم هو حبل الله المتين ، والذكر المكيم، والمعجزة الخالدة علئ مر الأزمان،

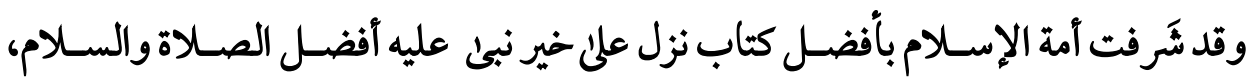

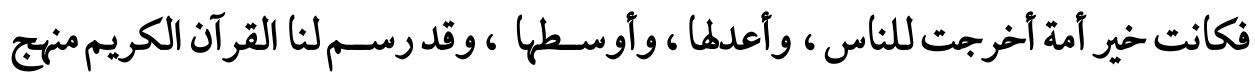

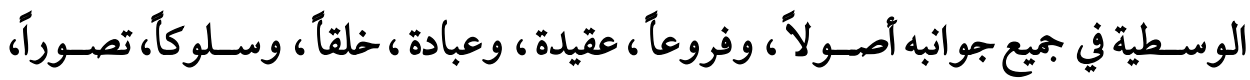
وعملاً. وقد اهتم الإ سلامبالأسرة المسلمة اهتجاما بالغاً، وأحاطها بسياج من الضوابط التي تكفل

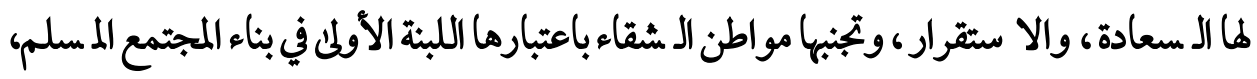
وتظهر وســية الإسـلام في تنظيمه للحياة الزوجية ، وحثه علن الوفاق بين الزوجين ، وحسـن

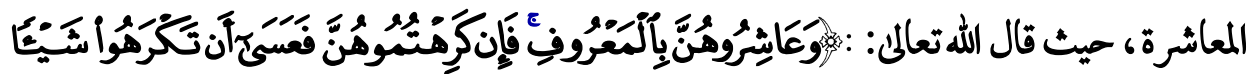




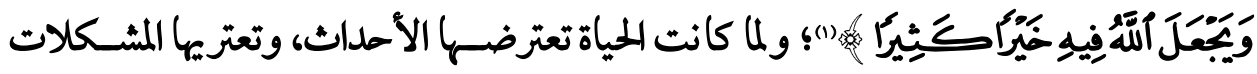
المختلفة دعا الإ سلام إلى المكمة والتريث في علاجها ، ويذل الجهد في معلجة الشقاق بين الزوجين، وهنا تبرز وسطية الإسـلام في معالجة هذا الشـقاق ، والمرص علإتحقيق الأمن للفردوالمجتمع ، والبعدعن أسباب تفكك الرباط الأسرى وما يترتب عليه من تشـتت، وضسياع للأبناء خاصسة وللأسرة عامة ؛ فكان اختياري لهذا الموضوع

\section{( بلاغة القرآن ووسطيته في معالجة الشقاق بين الزوجين )}

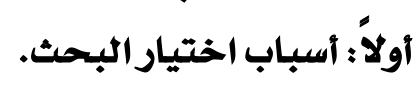

1- القرآن معجزة خالدة علئ مدئ الدهوروالأزمان، والدراسات البلاغية القرآية تثبتها وتوكدها.

$$
\text { r- ترسيخ جذور قوية للبلاغة القرآنية في الدراسات العربية. }
$$

r- إبراز بلاغة القرآن الكريم، ووسطيته في مواجهة المشكلات الأسرية.

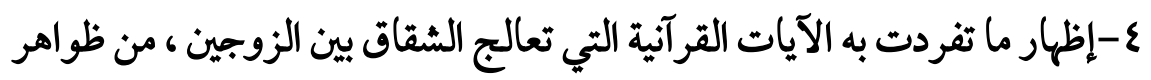

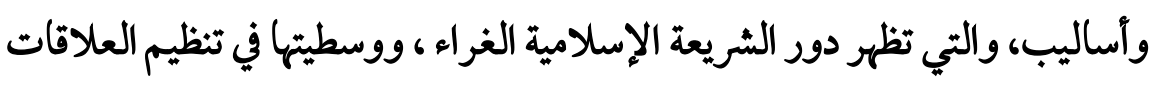

$$
\text { الزوجية، والبعد عن الشقاق والنشوز. }
$$

اعتمدت في هذه الدراسة على المنهج البلاغي التحليلي ، والذئ يتلخص فيا ياتئ:

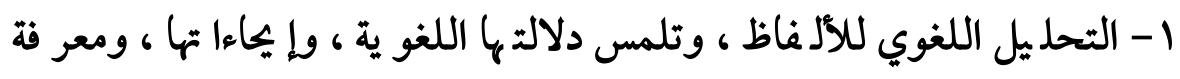

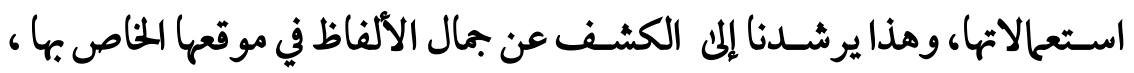

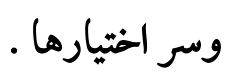

r- الإشـارة إلى سر التعبير القرآني لألفاظ الآيات دون غيرها من المترادفات ، وربط ذلك بالغرض المسوق له الكلام

(1) (1) سورة النساء: الآية(19). 
ثالثاً: خطة البحث.

وأما عن خطة البحث ، فتشتمل على مقدمة ، وتمهيد، ومبحثين، وخائة ، وفهرس

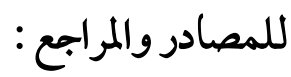

أولاً: المقدمة وتشتمل على أهمية الموضوع ، وأسباب اختياره ، والمنهج المتبع فيه، والخطة التي أعدت لإنجازه.

ثانياً: التمهيد ويشتمل على الحديث عن بلاغة القرآن ، وإظهار معانى الوسطية ، وبيان مفهوم الشقاق لغة واصطلاحاً، وبيان اهتحام الإسلام بالأسرة المسلمة ، ونبذة عن سورة النساء محل الآيات الكريمة التي عالجت قضية الشقاق بين الزوجين.

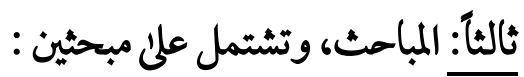
المبحث الأول: البلاغة القرآية في معالجة نشوز الزوجة. المبحث الثاني: البلاغة القرآنية في معالجة نشوز الزوج. رابعاً: الخاتمة، وتشتمل على أهم التتائج والتوصيات التي توصلت إليها في نهاية هذا البحث. وبعد ، فهذه محاولة متوا ضعة للو صول إلى بعض دقائق القرآن الكريم، فإن وفقت في ثيء من ذلك فبفضله سبحانه وتعاله، وإن كانت الأخرىا، فحسبي أني اجتهدت، والله أسأل أن يغفر لي ما جرى' به قلمي بلفظ لا يليق ، آو ذكر معنى يخالف مراده سـبحانه وتعالى في كتابه الكريم، كحا أ سالّه أن يفقهنا في الدين ، وآن يلهمنا الفهم الصحيح لآيات كتابه العزيز، إنه وله ذلك والقادر عليه. 


\section{ثقريد}

بلاغة القرآن

جاء القرآن الكريم فكان المعجزة اللالدة التي أعجزت العرب الفصحاء ، ووقفت دونها عقول البلغاء، وما استطاعوا إلى معارضته سبيلا ، فظهر عجزهم ، وخاطبهم الله بقوله

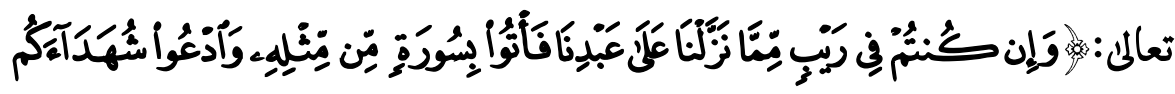

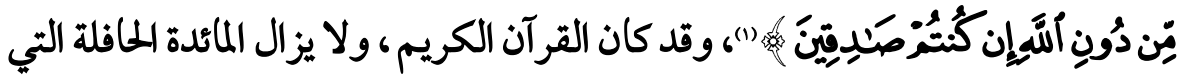
تتداعلى لما النفوس على اختلاف مشاربها ، ومنازعها وآهوائها ، فالمكتبة القرآنية ثرية بالكتب الباحثة عن مفرداته، وبجازه ، وإعرابه ، ويلاغته بداية من مجاز القرآن لأبى عبيدة، وعناية اللطابي، والباقلاني بالكشف عن وجوه الإعجاز، واحتفال الإمام عبد القاهر، والزخشري بالبحث عن آسرار النظم ، وغير ذلك من العلماء الذين ساروا في نفس الطريق من القدماء والمحدثين (r).

ويتسم الأسلوب القرآي الكريم بالمرونة والاتساق مع المشاهد واللوحات النابضة بحياة الموقف، حتى إننا لنجد الكلمة بذاتها تأتي في عدة سياقات ، ولما دلالة مختلفة في كل سياق بحسب ما يقتضيه المعني ويتطلبه المقام، ويقول الرافعى في بيان الأسلوب القرآني:" وكلما ازداد الزمان عمراً، وبلغ الدهر شأواً وغاية انبثقت أساليب القرآن وكلماته ؛ لتشع بضوئها ونورها؛ لتنطلق كائنات الوجود من جديد بمراميه ودلالته، ، وما آشبه القرآن الكريم في تركيب إعجازه، وإعجاز تركيبه بصورة كلامية من نظام هذا الكون الذي اكتنفه العلماء من كل جهة، وتعاوروه من كل ناحية، وأخلقوا جوانبه بحثا وتفتيشا، ثم هو بعد لا يزال

(1) (1) سورة البقرة: الآية (Yr).

(Y) يراجع: من جمال النظم القرآنئ في سورة إبراهيم دراسة تحليلية بلاغية، د، صلاح الدين محمد

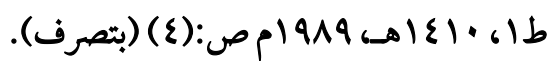


عندهم علن كل ذلك خلقاً جديداً، ومراماً بعيدا، وصعبا شديدا "(1).

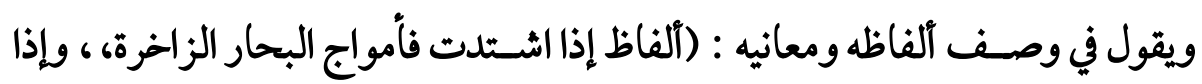
هي لانت فأنفاس الحياة الآخرة، تذكر الدنيا ، فمنها علادها ، ونظامها وتصـف التهات الآخرة

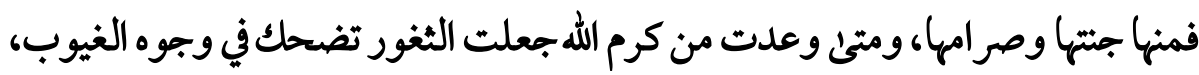

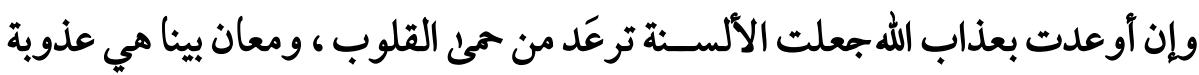
ترويك من ماء البيان، ورقة تستروح منها نسيم المنان، ونور تبصر به في مرآة الإيانان وجه

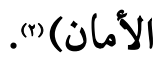

والفهم الصسحيح لما يرمئ إليه القرآن طريقه هو النص القرآني نفسـه بمعنى التعرف علنى

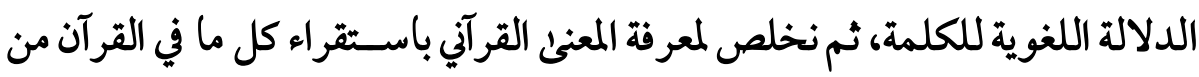
صـيخ اللفظ، وبذلك يعد نظم النص القرآني هو العمدة والمعول في اسـتخراج المعاني

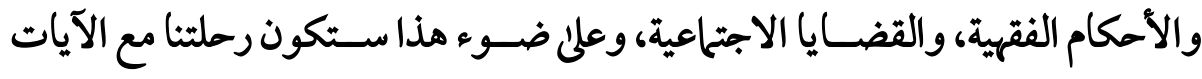
القرآنية من سورة النساء، والتي عالجت الشقاق بين الزوجين.

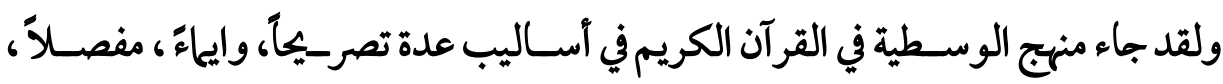
وبجملاً، خبرا وانشاء، أمرا ونهيا ، ولنبداً بوقفة موجزة مع تحديد لوند معنى الوسطية .

مفهوم الوسطية لفة واصطلاحماً الوسطية هِ2 اللغة: جاءت كلمة (وسط) في اللغة لعدة معان، ولكنها متقارية في مللوما عند التأمل في حقيقتها ومآما. قال ابن فارس: (وسط): الواو والسين والطاء: بناء صحيح يدل على العدل والنصف،

(1) يرابع: إعجاز القران والبلاغة النبوية مصطفي صادق الرافعي ،طع، مطبعة الاستقامة بالقاهرة ،

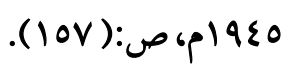

(Y) يرابع: إعجاز القران والبلاغة النبوية، ص:(Yr). 


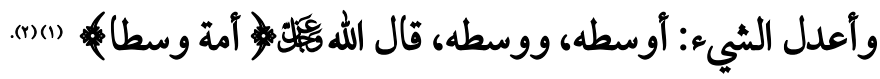
ويمكن إجمال المعاني التي جاءت تدل عليها هذه الكلمة فيا يلي : 1- (وسط) بسكون السين تكون ظرفا بمعنى (بين)، تقول: جلست وسط القوم، أي: بينهم"(r) وتأتي

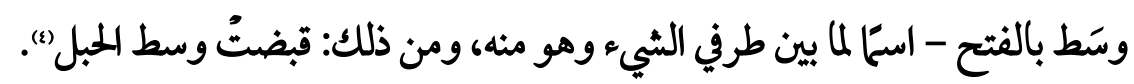

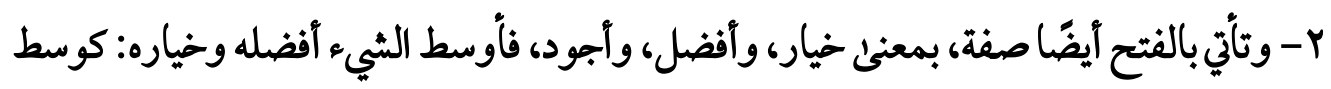

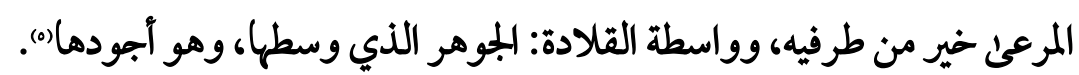

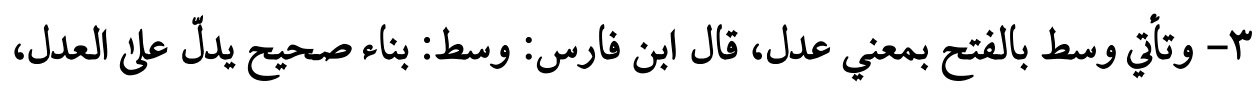
وأعدل الشيء أوسطه ووسطه (1)، ع- وتأتي (وسَط) بالفتح أيضا للشيء بين الجيد والرديء"(i)، ومنه ما ورد في المديث الشريف

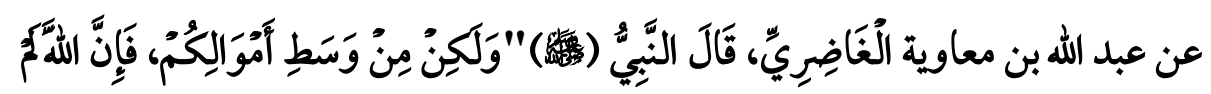

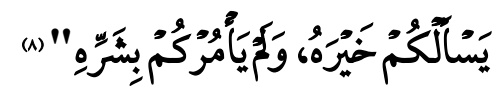

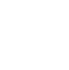

(1) يراجع: معجم مقاييس اللغة ، أمد بن فارس ، تحقيق: عبد السلام محمد هارون، دار الفكر ،

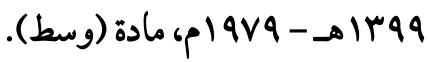

$$
\begin{aligned}
& \text { (Y) سورة البقرة: من الآية (r) (Y) ). }
\end{aligned}
$$

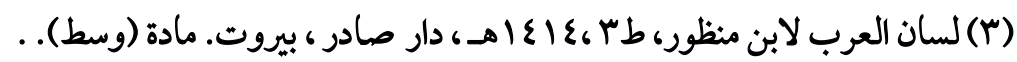

$$
\begin{aligned}
& \text { (ع) يراجع: السابق مادة (وسط). } \\
& \text { (0) يرابع: لسان العرب مادة (وسط). } \\
& \text { (7) يراجع: معجم مقاييس اللغة مادة (وسط). } \\
& \text { (V) يرابع: مادة (وسط) في الصحاح. }
\end{aligned}
$$

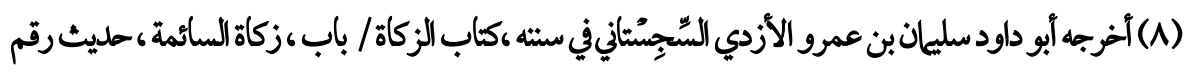

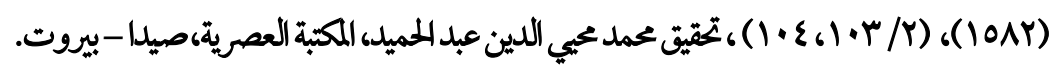




\section{مفهوم الوسطية هِ الاصطلاح:}

عرف بعض العلماء المعاصرين الوسطية بأنها: مؤهل الأمة الإسلامية من العدالة، والخيرية للقيام بالشهادة على العالمين، وإقامة الحجَّة عليهم" (1). وإذا أضــيفت المعاني السـابقة إلى الأمة الإســلامية ، فيكون المراد بذلك أنها قد بلغت بصــفاتها المحمودة المكتسـبة من شرع الله تعالهي مكانة في الاعتدال والمليرية والإنصـاف ، والرفعة ما يجعلها سيدة الأمم، وقائدة الشعوب ، وشاهدة عليهم يوم يقوم الأشهاد. استعمالات كلمة الوسطية يِ القرآن الكريم: وردت كلمة (وسط) في القرآن في عدَّة مواضع، وذلك بتصاريفها المتعدّدة.

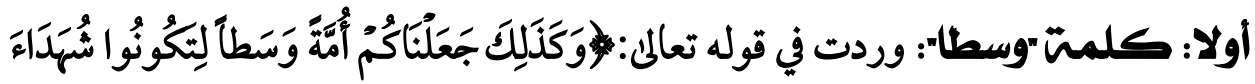

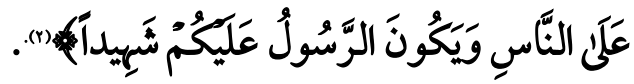
ثانيًا: كلمت الوسطى" وقد وردت هذه الكلمة في قوله سبحانه:\$حَافِظُوا عَلَّى

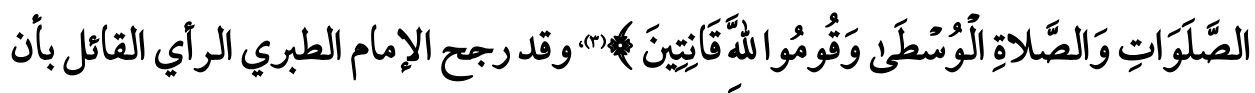
الصّلاة الوسطى هي العصر (8). ثالثا: هعلمتَ (أوسط) ، وقد وردت هذه الكلمة في آيتين:

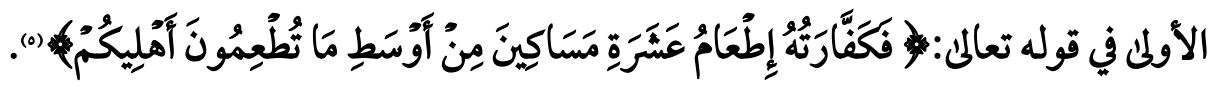

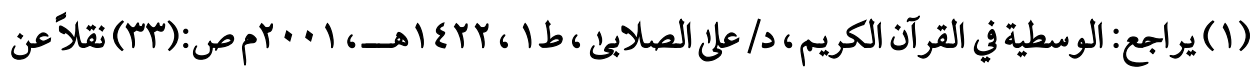

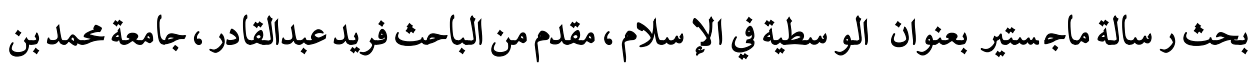
سعودص:(YQ). (Y) سورة البقرة: من الآية (Y؟ ( ).

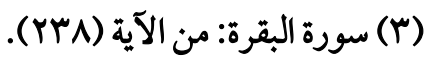

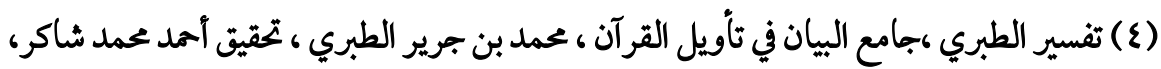

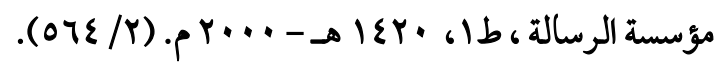
(0) سورة المائدة :الآية (19). 


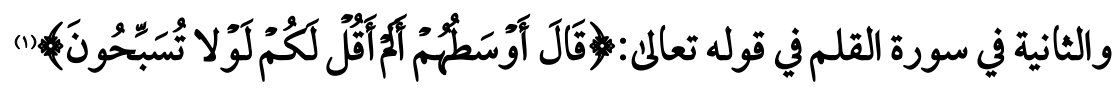

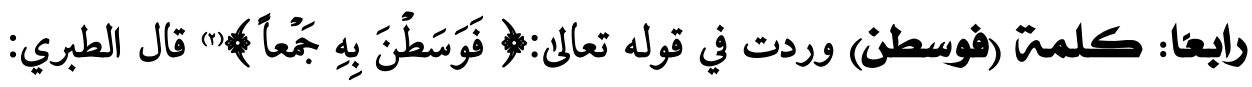
(وسطن جمع القوم)(r).

ومن خلال ما سبق يتين لنا أن المعاني اللغوية لكلمة (وسط) كلها متقارية ، تدور حول العل، والإنصاف.

\section{مفهوم الشققاق لفة واصطلاحماً}

الشقاق في اللفة:

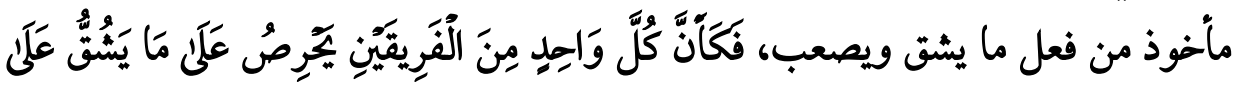

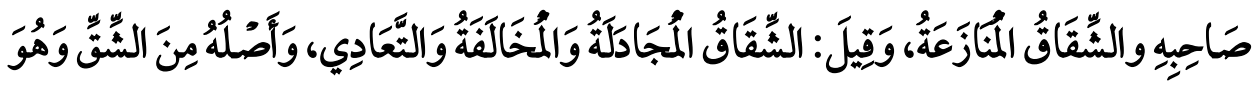

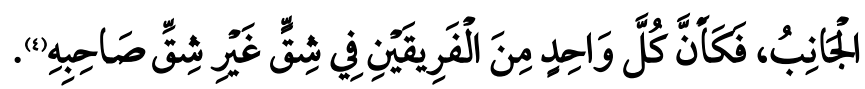
الشقاق ي- الاصطلاح: هو وقوع الخلاف والعداوة بين الزوجين على نحو يستلدئ تدخل الآخرين للإصلاح

بينه|l(o)

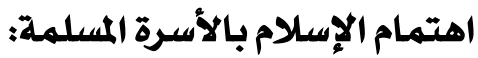

لقد اهتم الإسلام بالأسرة المسلمة اهتحما كبيرا، فنظر إلى الزواج نظرة ملؤها الإجلال المال والإكبار، فجعله ميثاقاً غليظاً، ومنحه كثيرا من العناية وجعل العلاقة بين الزوجين قائمة

$$
\begin{aligned}
& \text { (1) سورة القلم :الآية (YN). } \\
& \text { (Y) سورة العاديات: الآية (0). } \\
& \text { (Y) يراجع: تفسير الطبري (ع Y/ ع OT). }
\end{aligned}
$$

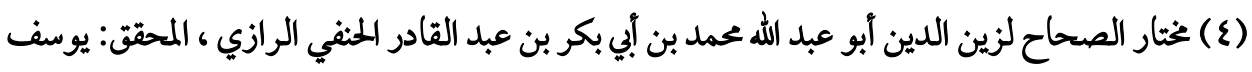

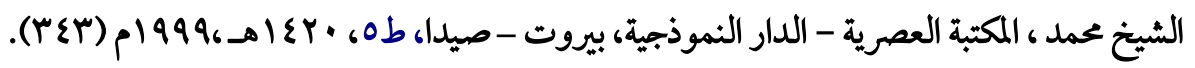
(0) البناية شرح المداية، لأبئ عحمد محمود الغيتابئ بدر الدين العينئ ، دار الكتب العلمية - بيروت، لبنان،

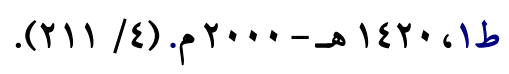


على الستر والتكامل وتربية الأبناء تربيةصالحة قائمة علنى دين اللهعز وجل ، وتحدث عن جملة من الو سائل التي إذا روعيت كانت وقاية للحياة الزوجية من التدهور ، ومن هذه الو سائل

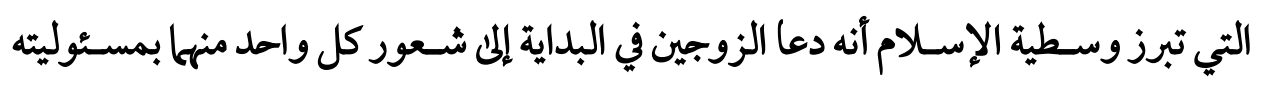

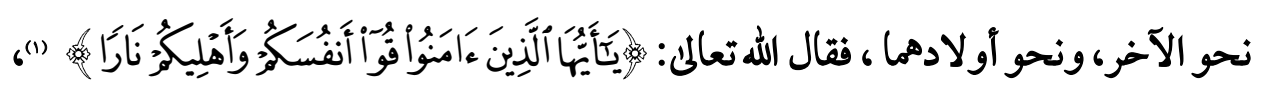

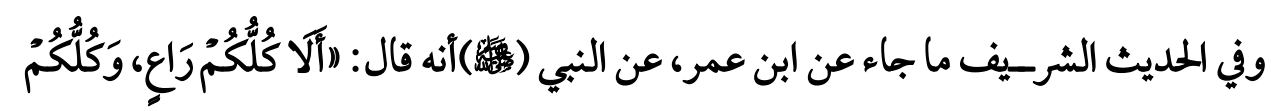

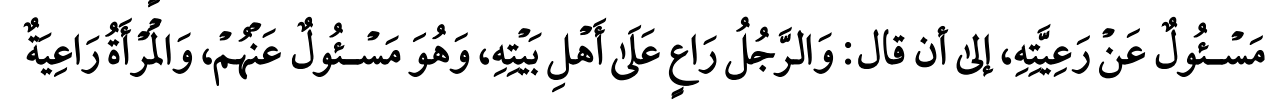

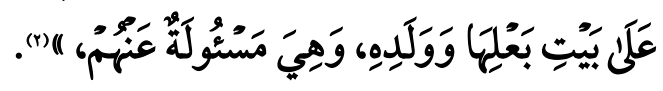

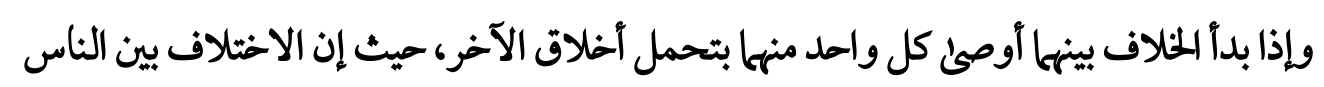

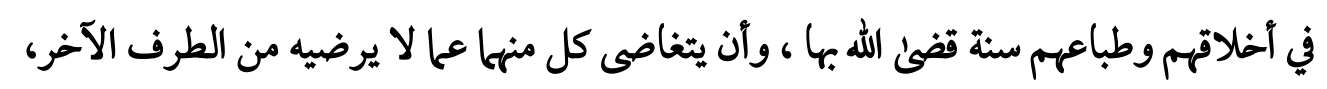

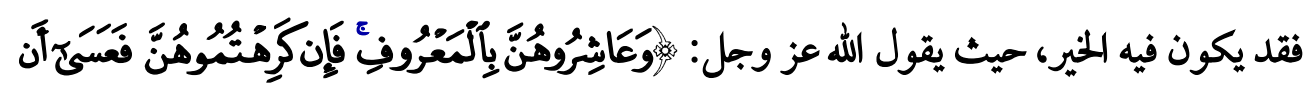

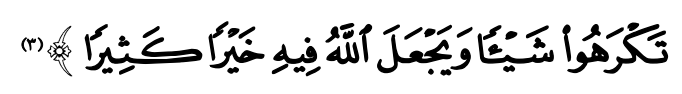

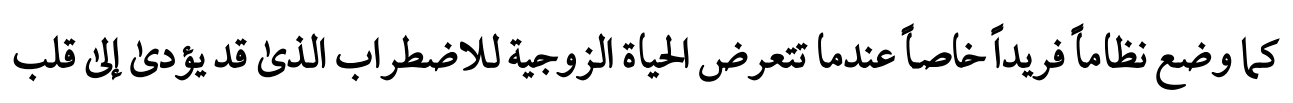

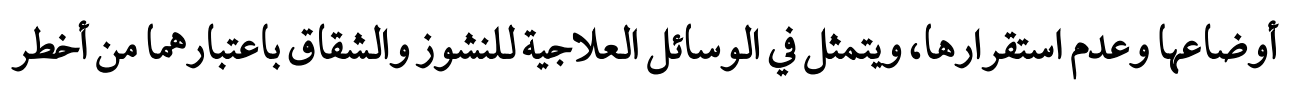
الأمراض التي تعصف بالحياة الزوجية، وتهدد أمنها، وتؤثر سلباً على الفرد والمجتمع، وتؤدئي

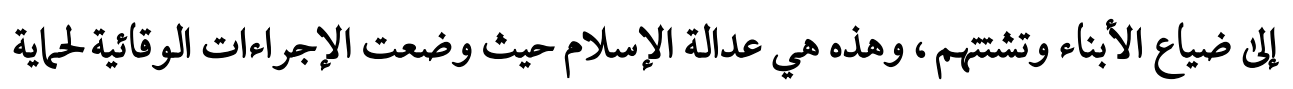

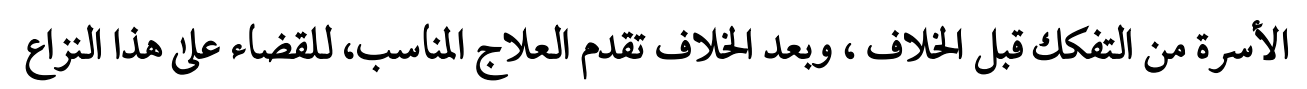
الذئ يهدد الرباط الأسرى ، وينذره بالتشتت والضياع.

(1) سورة التحريم: الآية (7).

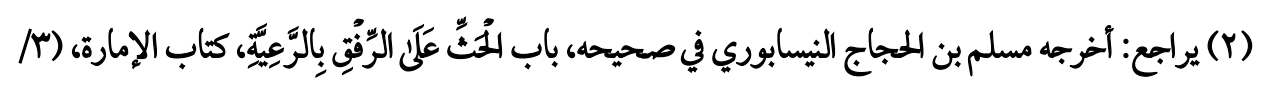

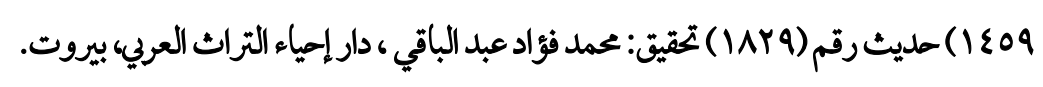
(Y) سورة النساء : الآية (19). 
وتظهر وسطية الإسلام ظهوراً ساطعاً عندما آراد آن يعالج نشوز الزوجة؛ فوضع الوسائل

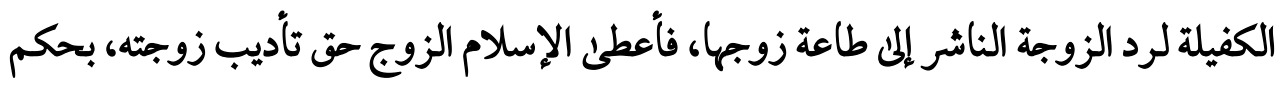

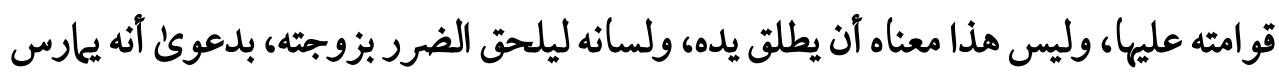

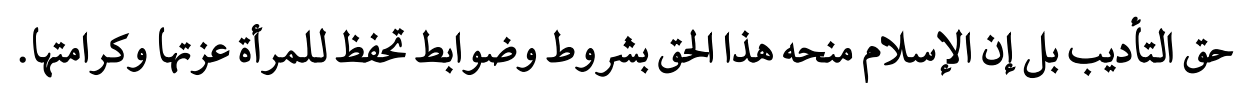

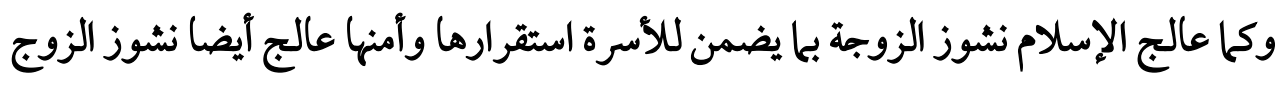

$$
\text { با يجقق للزوجين الأمن والسكينة }
$$

ويسير الإسلام علنوسطيته حتى إذا تفاقم الأمر بين الزوجين، ولميكن هناك سييل للإصلاح، نهن كلا

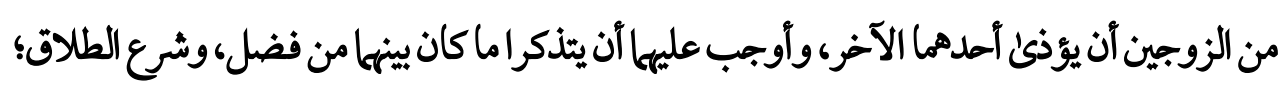

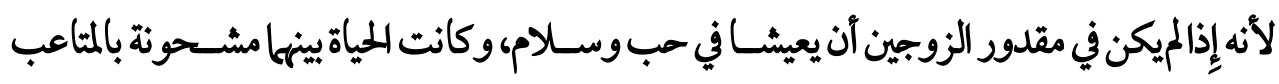
والمصاعب، فإن العاقبة ستكون سيئة بالنسبة لمحا، ولأولادهما .

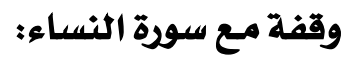

سورة النساء سورة مدنية، وتسمى سورة النساء الكبرىن، لتمييزها من سورة النساء الصغرئ،

وهي سورة الطلاق، وعدد آيات سورة النساء (IVT) آية، وعدد كلماتها (YV (Y) كلمة (1). وهم من السور التي تفيض بالأمكام التشريعية المتعلقة بتظيم الأسرة وحقوق المرأة، ونظام اللحكم، وتقويم العدالة وضبط حقيقتها، كا بينت سورة النساء أن الزواج شركة تعاونية أساسها المودة، والرمة والوفاء والألفة () ، وكان الشقاق بين الزوجين من المنان المحاور التي اشتملت عليها السورة الكريمة، وعالجها القرآن الكريم بمنهج قائم علن الوسطية والاعتدال دون إفراط، أو تفريط في حق من حقوق الزوجين ، مما يؤدئ إلى تحقيق الأمن والاستقرار

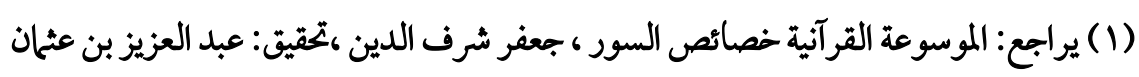

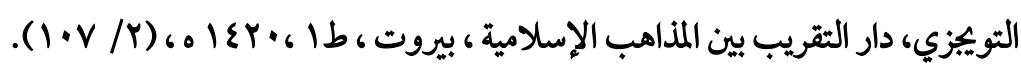

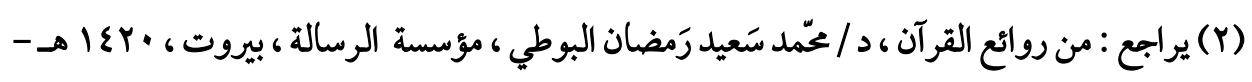

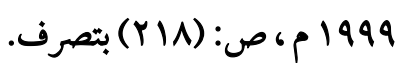


لأفراد الأسرة خاصة وللمجتمع عامة ومجموع الآيات التي عالجت الشقاق في السورة الآية

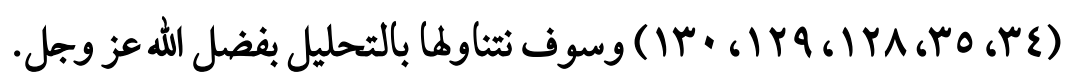




\section{المبعث الأول}

\section{البلاغة القرآنية في معالجة نشوز الزوجة}

\section{بِنس}

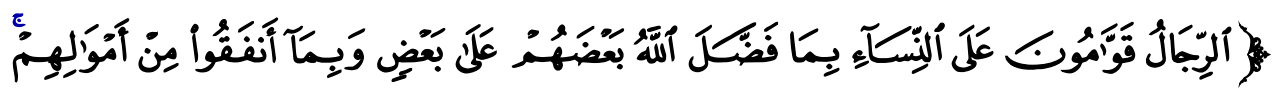

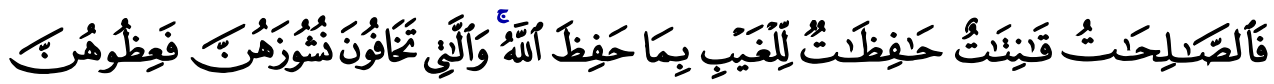

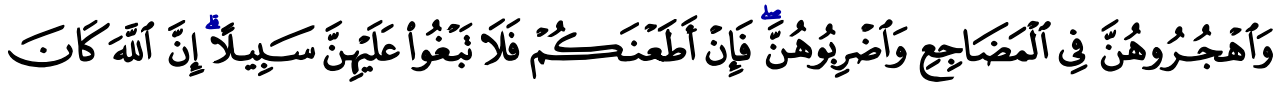

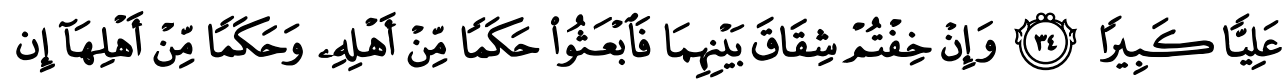

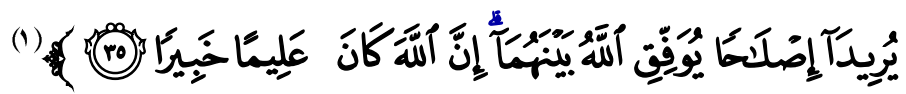

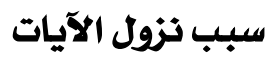
نزلت هاتان الآيتان في بنت محمد بن سلمة وزوجها سعد بن الريبع أحد نقباء الأنصار، فإنه

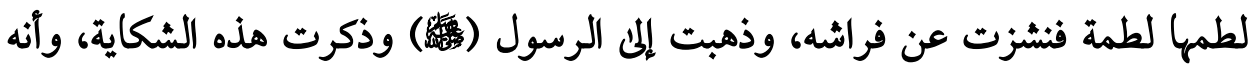

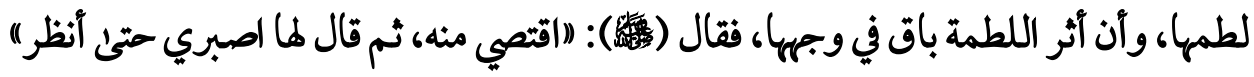

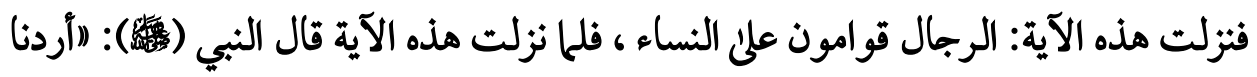
أمرا وأراد الله أمرا والذي أراد اللهخير)(r).

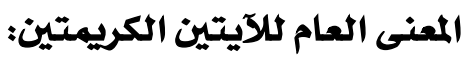
تتضمن الآيتان الكريمتان معانيل جليلة تضمن للأسرة المسلمة استقرارها وسعادتها ، فبينت

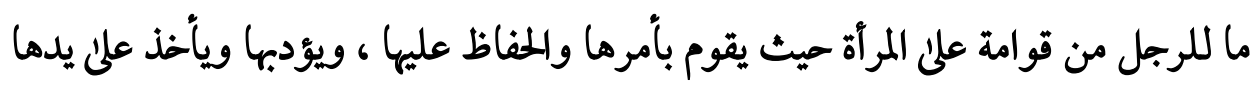
بحق ما فضله الله به عليها من علم وعقل، وولاية ، ثم توضح لنا الآيات صفات المرآة

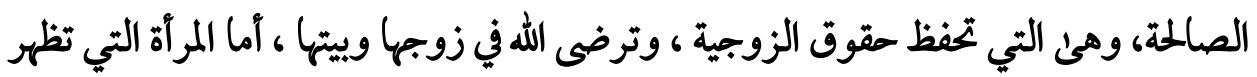

$$
\text { (1) (1) سورة النساءألآيتين (ع بأمبr). }
$$

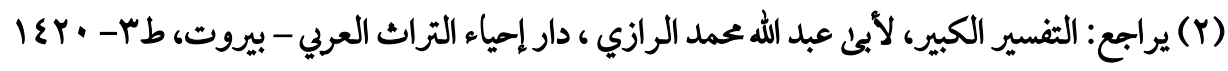
. ( $(v \cdot / l \cdot)^{-1}$ 
عليها أمارات النشوز، والترفع علن الزوج ، فعلن الزوج وعظها ومحاورتها باللين ، فإذا لم

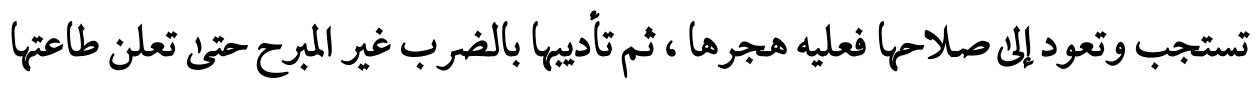

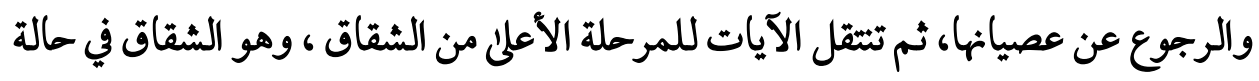
ما إذا انتشر الخلاف بين الزوجين ولميعلم من المتسبب فيه، واستعلنت الخصومة بين الزوجين، فعلى أولى الأمر في هذه الحالة بعث حكمين من أهليها ، إن أرادا الصلح بينها وفقهها الله تعالثى، وإلا كان كل منها وكيلا لصاحبه في الفرقة ، والله عليم بكل شئ خبير ببواطن الأمور وظواهرها.

التحليل البلاغي للآيتين الكريمتين:

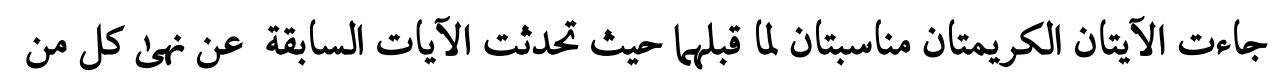
الرجال والنساء عن تمنى ما فضل الله به بعضهم على بعض ، وأرشدهم إلى الاعتماد في أمر

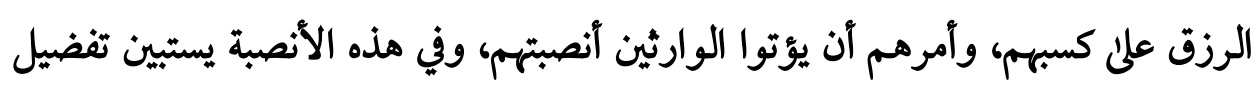

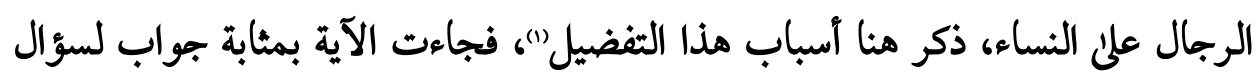

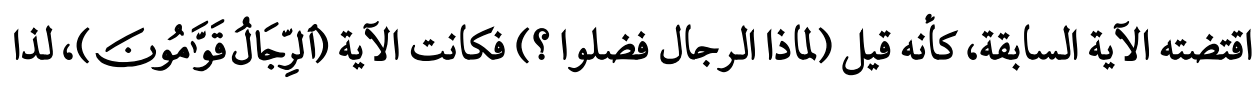

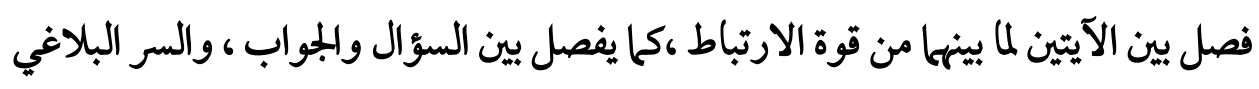

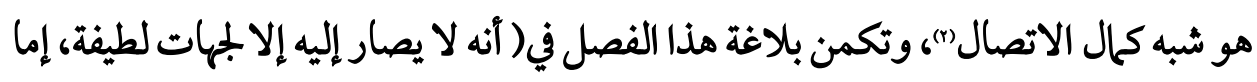

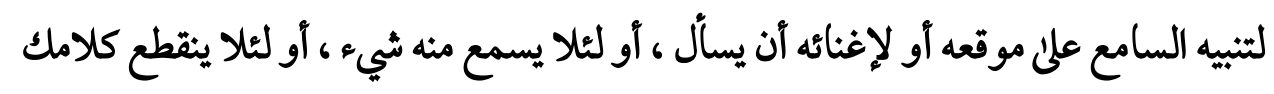

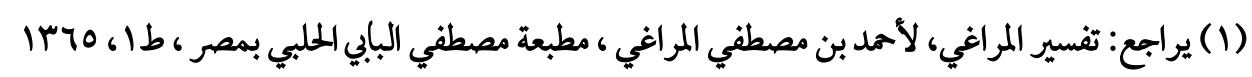

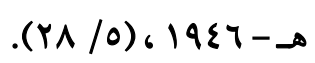
(Y) وكمال الاتصال هو: كون الجمملة الثانية بمنزلة المتصلة بالجملة الأولى ؛ لكونها جوابا عن سؤال اقتضته

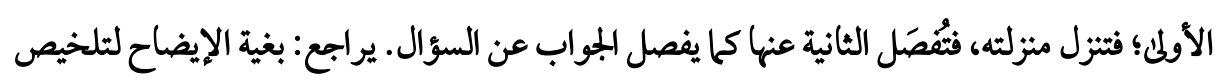

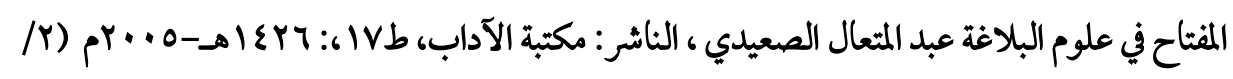


بكلامه، أو للقصد علي تكثير المعنى بتقليل اللفظ، وهو تقدير السؤال وترك العاطف، أو غير

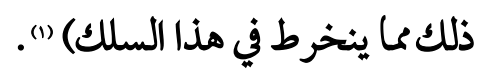

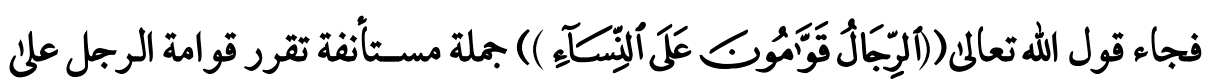

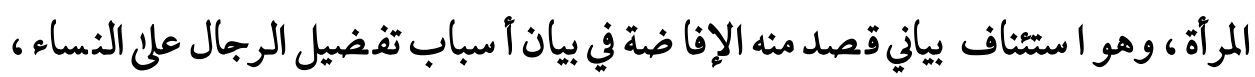
والتمهيد لبيان أحكام تخص الأزواج والزوجات ، وهذا قمة البلاغة من التمهيد والتدرج في لئي طرح الحكم الشرعي ، فكانت الجملة بمثابة المقدمة التي تشتمل علن حكم شرعي كلي تتفرع

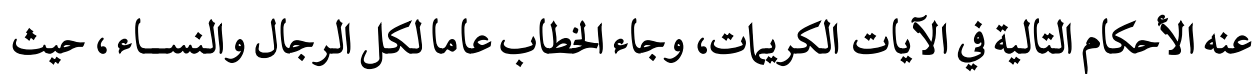

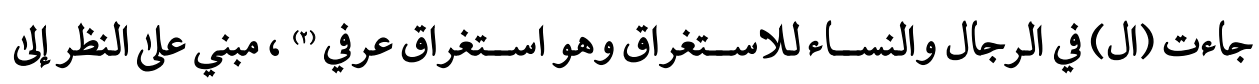

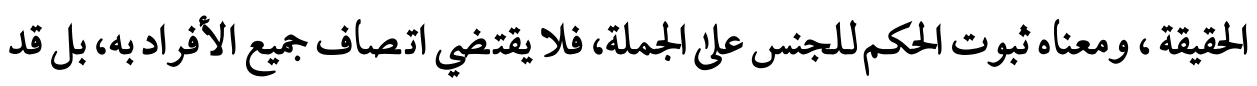

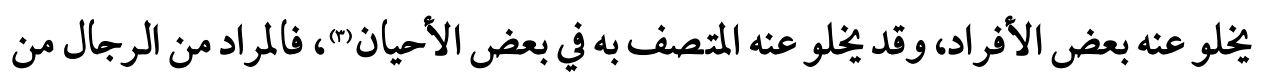

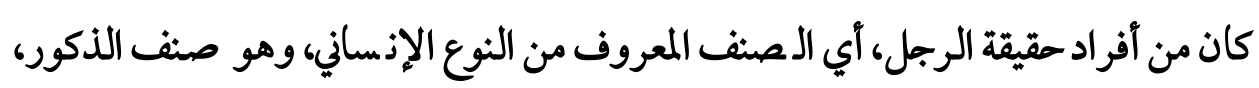

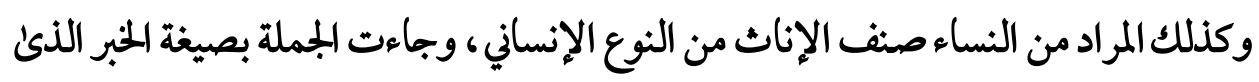

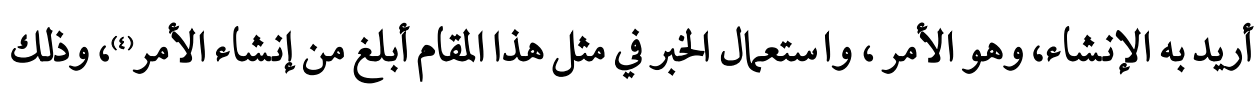

(1) يرابع: مفتاح العلوم للأبئ يعقوب يوسف السكاكي ، دار الكتب العلمية، بيروت، لبنان، طج؟،

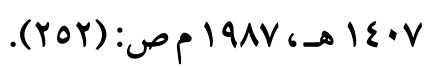

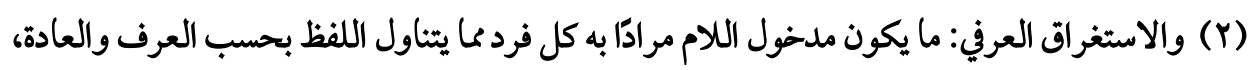

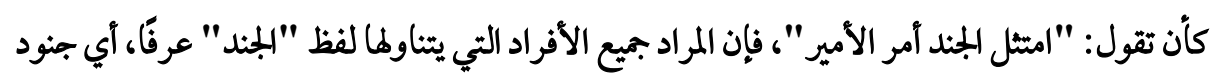

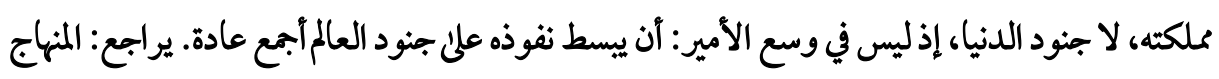

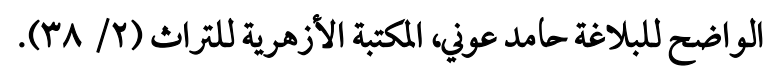

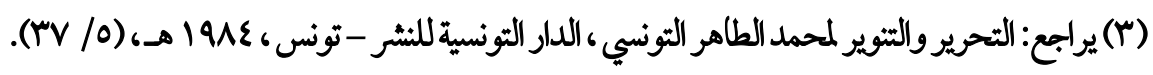

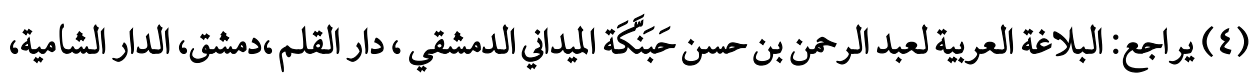

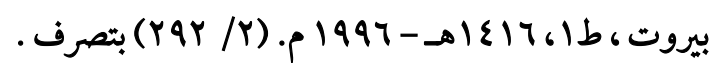


لأ نها أظهرت الحرص على وقوع المطلوب ، وأنه يجب علن الر جل القيام بشـؤون زوجته

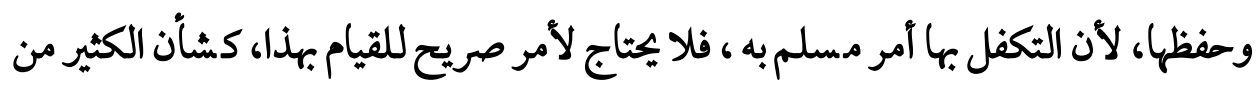
الأخبار الشرعية")، ويقول الزركثي (فإنما يجيء الأمر بلفظ الخبر الحاصل تحقيقا لثبوته، وأنه

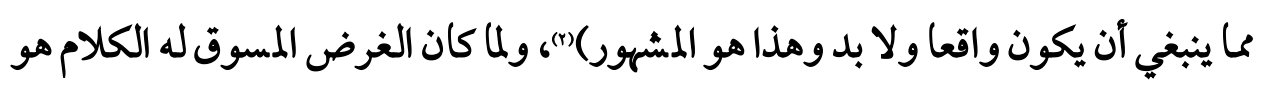
مدح الرجل ، وبيان قوامته علن المرآة جيء بالجملة الاسـمية التي (تفيد الثبوت لتفيد معه وليه

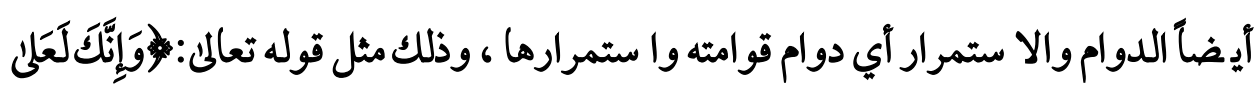

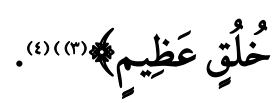
والقيم: السـيد، وسـائس الأمر ، وقيم المرأة: زوجها ، وقام الرجل علني المرأة: صـانها، وإنه

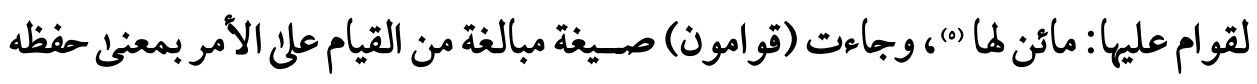

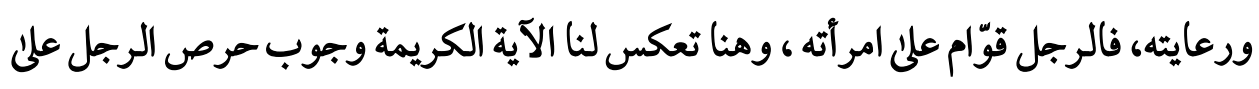

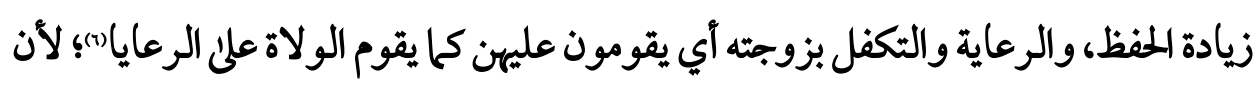
شـأن من يهتم بأمر أن يقوم لقضـائه ، قال الرازي (القوام اســـملمن يكون مبالغا في القيام

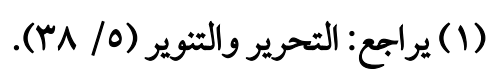

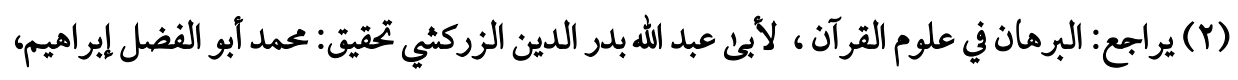

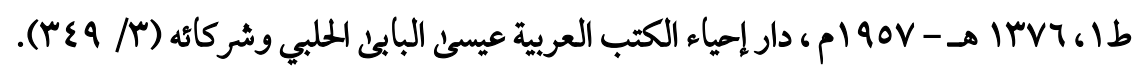

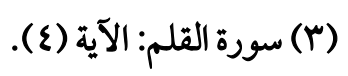

(ع) يرابع: علوم البلاغة البيان، المعاني، والبديع، أهمد مصطفي المراغن،، طا، دار الآفاق القاهرة -

$$
\text { (0) }
$$

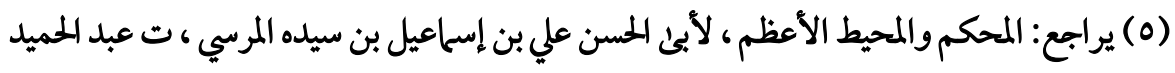

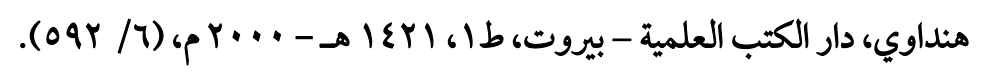

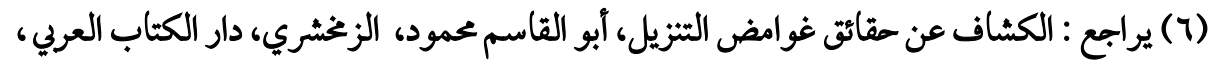

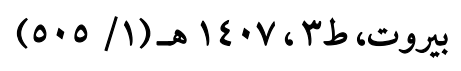


بالأمر، يقال: هذا قيم المرأة وقوامها للذي يقوم بأمرها ويهتم بحفظها) (1).

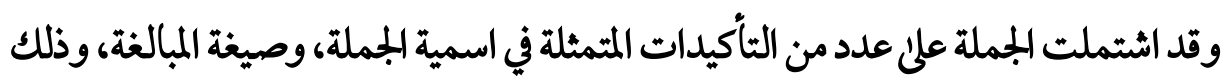
للإثارة إلى كامل الرئاسة والولاية، فالرجال لمم حق الأمر، والنهي، والتدبير والتأديب، وعليه كامل المسؤولية في الحفظ والرعاية والصيانة، وهذا هو السر في بجيء الجملة اسمية، التي آفادت ثبوت مذه الحقوق له ، والواجبات عليه.

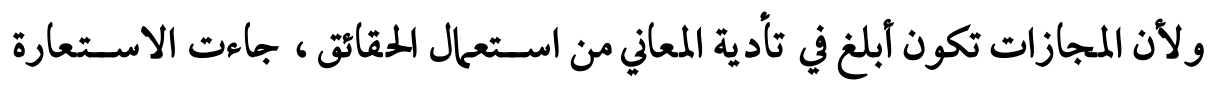

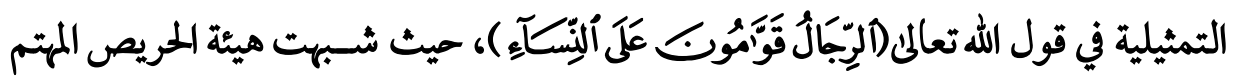

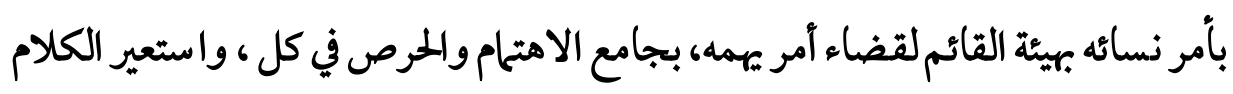

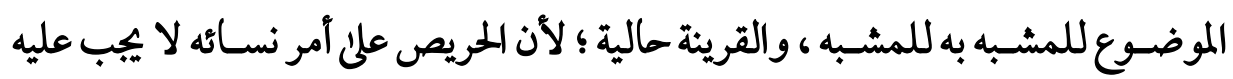
القيام دائجاً .

وقد ظهرت البلاغة القرآنية في هذا التصوير البارع الذئ عبر عن الغرض المقصود مع الإيجاز، وييَّت لنا الآية ما يجب علن الزوج تجاه زوجته في صورة حسية ، فكان لها الأثر

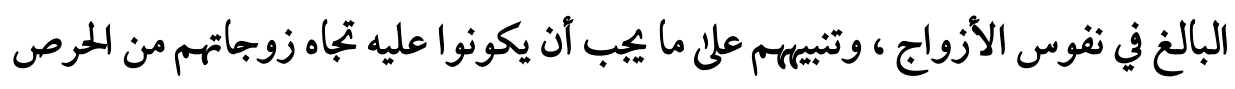
والقيام على مصالمهن.

والاستعارة التمثيلية أبلغ أنواع المجاز مفرداً أو مركباً، و إحدى الحجج على إعجازه (لأنها تضع أمام المخاطب بدلا من المشبه صورة جديدة تملك عليه مشاعره، وتذهله عحا ينطوي تحتها من التشبيه، وعلئ مقدار ما في تلك الصورة من الروعة، وسمو الحزيال، تكون البلاغة في الاستعارة)(ب)، ويجوز أن يكون بجازا مرسلا علاقته اللزومية ؛ لأن شأن الذي يهتم بالأمر،

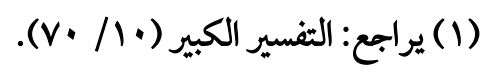

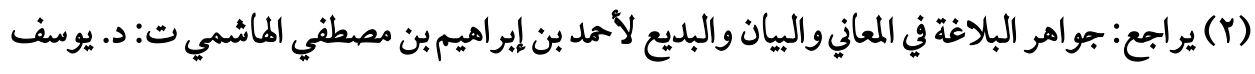
الصميلي، المكتبة العصرية ، بيروت ص: (YVV) 
ويعتني به أن يقف ليدير أمره، فأطلق على الاهتحام القيام بعلاقة اللزوم ، والقيام هنا بجازئ

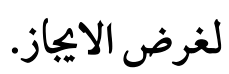

ومنا تظهر و سطية الإسلام ، حيث إن اللخصائص التي منحها الله سبحانه وتعالثى للرجل من قوة وشجاعة ورياطة جأش ، وتحمل للمشاق والصعاب تتناسب ، وهذه المهمة التي

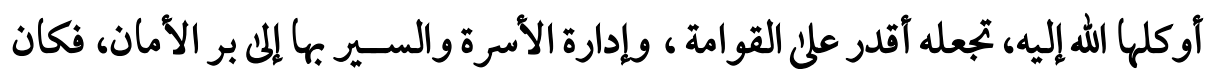

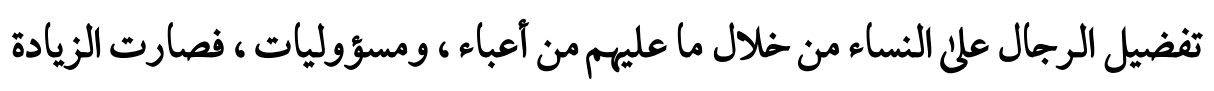

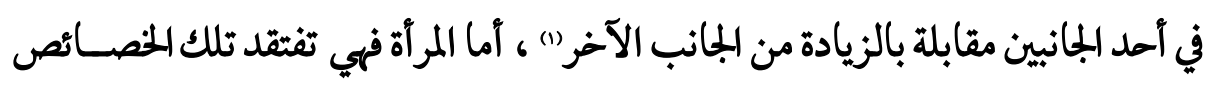
الموجودة عند الرجل ومي غير مؤهلة للقوامة ؛ لأنها زودت بخصائص تتناسب ومهمتها

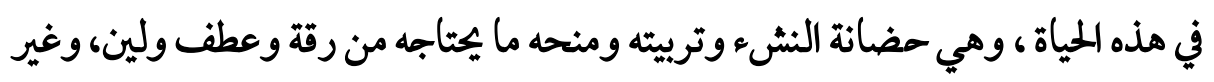

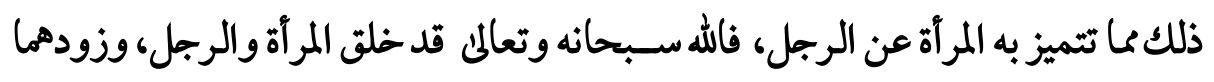

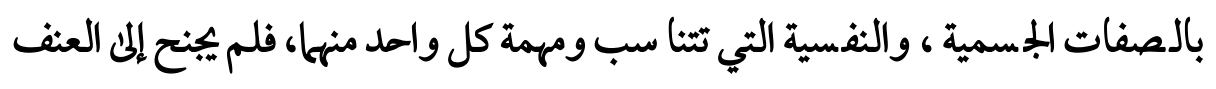
أو الإلزام الإجباري بتكليف المرأة بحا لا تسـتطيع القيام به ، ولكن مع حفظ حقوقها والأمر بحسن عشرتها.

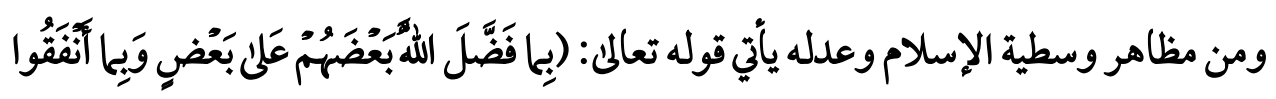

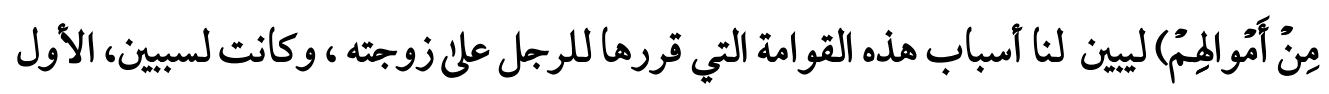

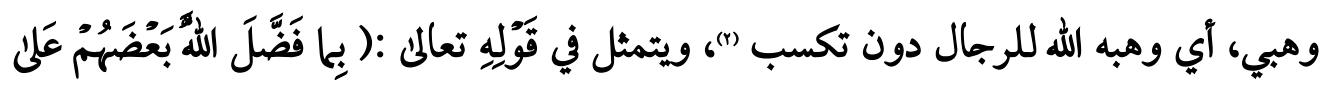

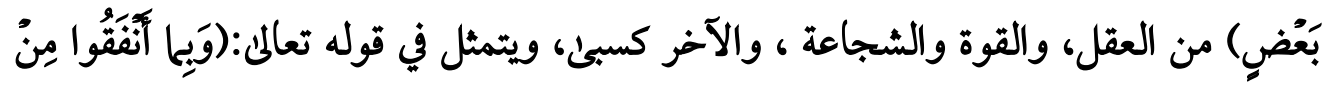

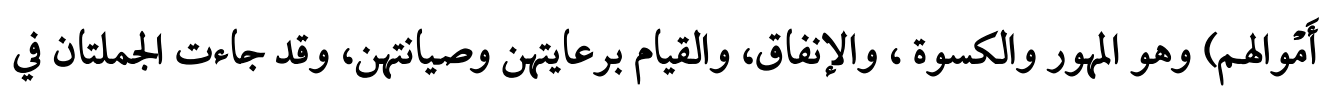

(1) يرابع: نظم الدرر في تناسب الآيات والسور لإبراهيم بن عمر البقاعي ، دار الكتاب الإسلامي،

$$
\begin{aligned}
& \text { القاهرة، (YV / / ) (YV). }
\end{aligned}
$$

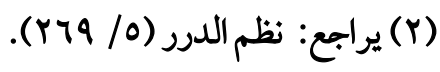


قالب صالح للمصدرية والموصولية، فالمصدرية مشعرة بأن القوامة سبيها تفضيل من اللهوإنفاق، وفيها جزالة لا توجد في قولنا (بتفضيل الله وبالإنفاق)، والموصولية يكون بمعنى ( بالذي فضل الله) وهل مشعرة بأن سبب القوامة ما يعلمه الناس من فضل الرجال ، ومن ونس إنفاقهم ليصلح

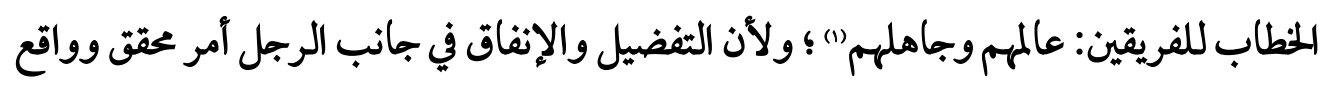

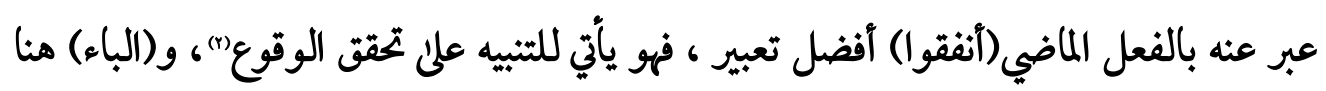

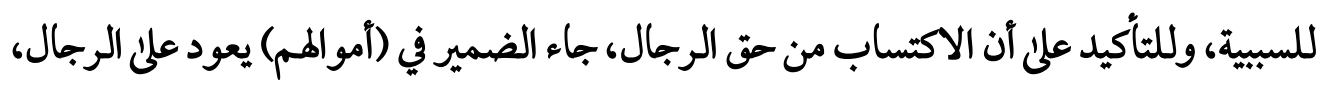

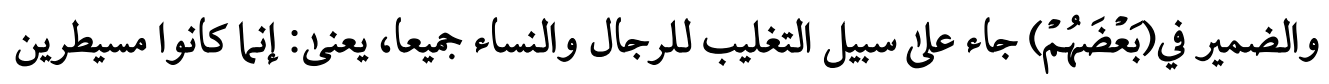
عليهن بسبب تفضيل اللهبعضهم وهم (الرجال) علئ بعض وهم (النساء)، وفيه دليل على أن الو لاية إنما تستحق بالفضل لا بالتغلب والاستطالة والقهر (r).

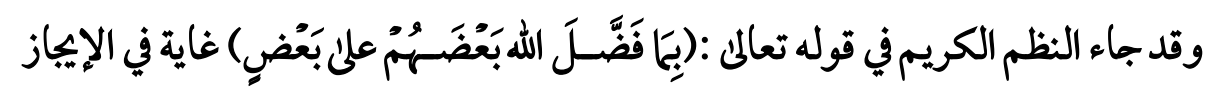
والإعجاز؛ لإيثاره التعبير بهذه الصـيغة دون غيرها، لأنه أوجز وأخصرسـ والتعبير بها، جاء

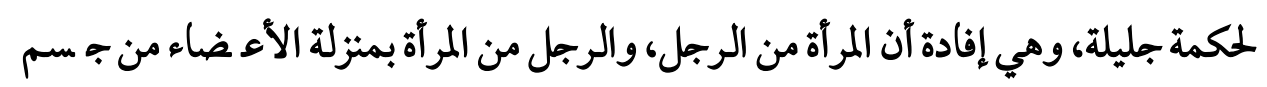

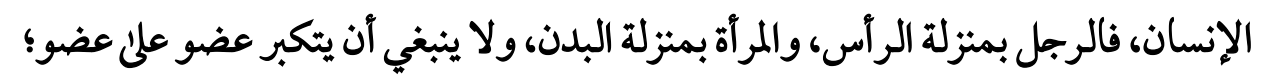

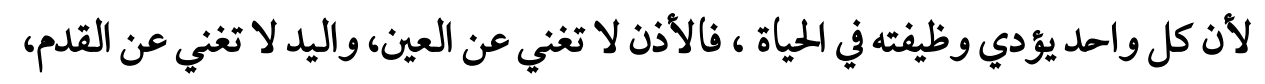

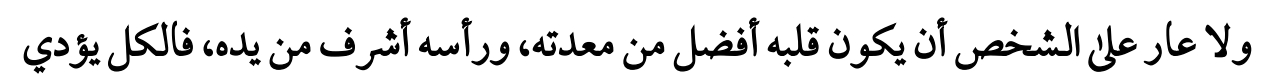
دوره بانتظام، ولا غنى لواحد عن الآخر()، و هذه قمة الوسـطية التي يدعو إليها ديننا

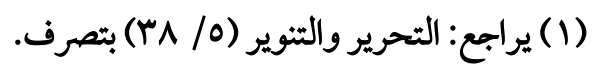

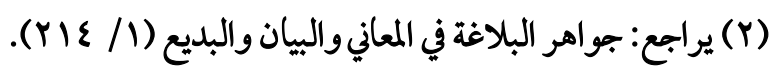

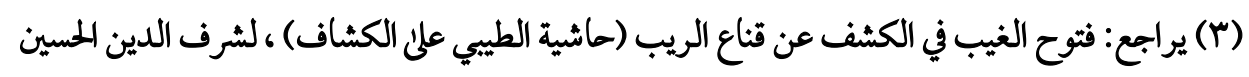

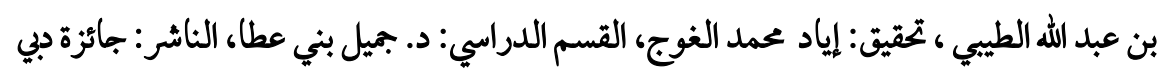

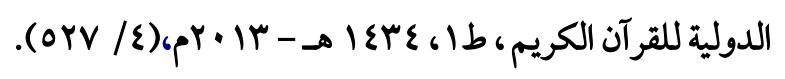

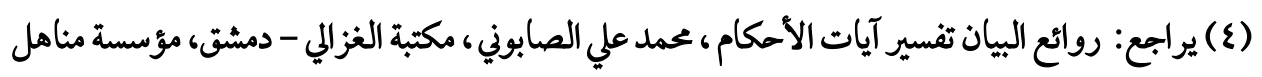


المنيف، ثم للتعبير حكمة أخرى وهي الإثـارة إلى أن الثفضسيل في الآية الكريمة تفضـيل

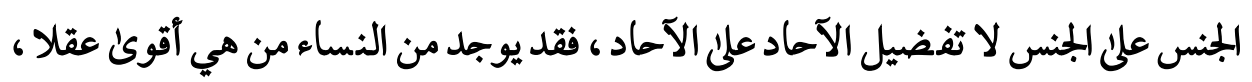
وأكثر معرفة من بعض الرجال، وبهذا جاء النظم القرآي غاية في الإعجاز.

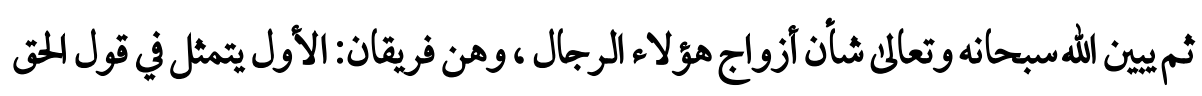

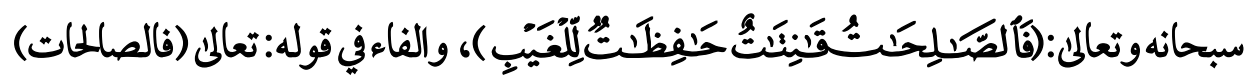
للفصيحة)، اقتضت الترتيب، أي إذا كان الرجال قوامين على النساء، فمن المهم تفصيل أحوال الأزواج منهن ومعاشرتهن أزواجهن وهو المقصود، فوصف اللهتعالثى الصلحات منهن وصفا يفيد

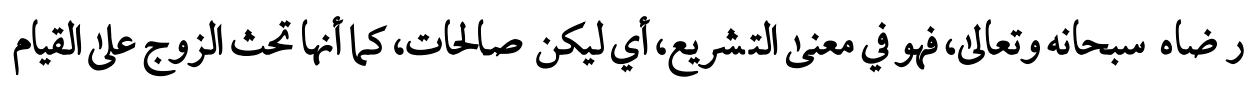

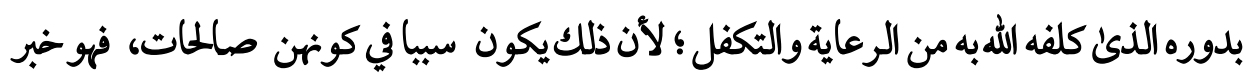

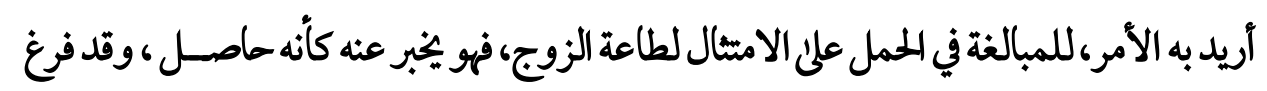

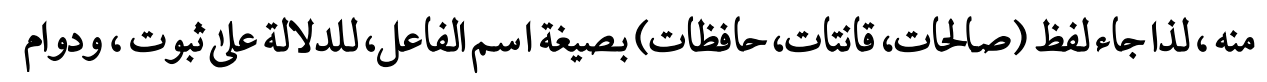
صفات الصلاح والقنوت والمفظ لديهن مع تجددها واستمرارها، ويقول الامام عبد القاهر (فأما وأنت تحدث عن هيئة ثابتة، وعن شيء قد استثقر، ولميكن ثم تزايدوتجدد، فلا يصـلح فيه إلا (") الاسم) وتسـتمر الآية الكريمة في تقديم ما ييعل العلاقة الزوجية أكثر ســوية ، وتناغاً ، من

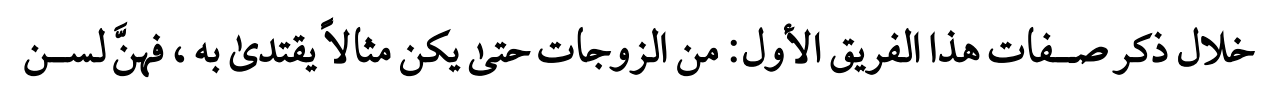

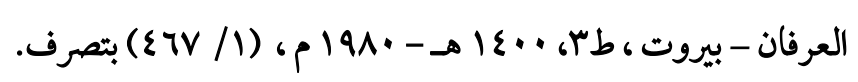

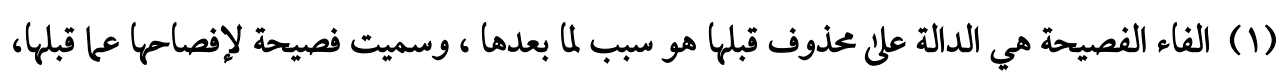

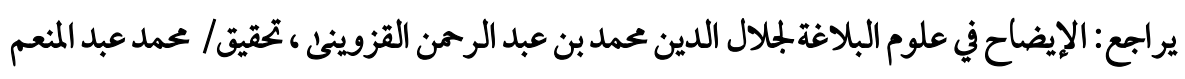

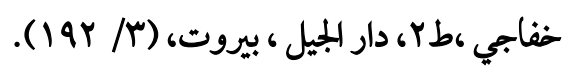

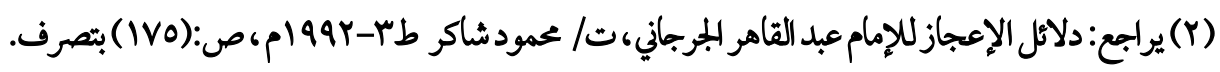


صالحات فقط، بل هن قانتات ، والصلاح نقيض الفساد، فلمرآة الصالحة إذا تزوجت صلح

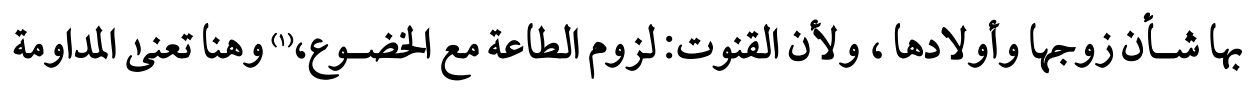

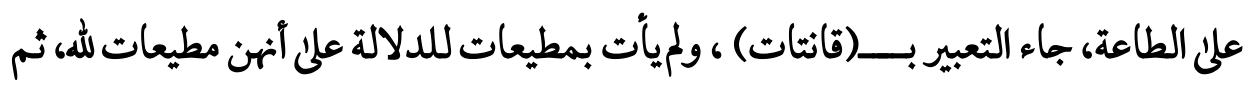

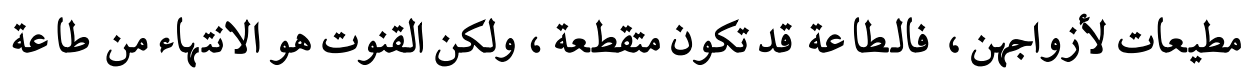

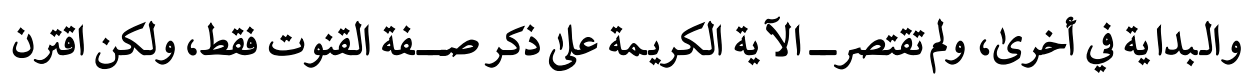

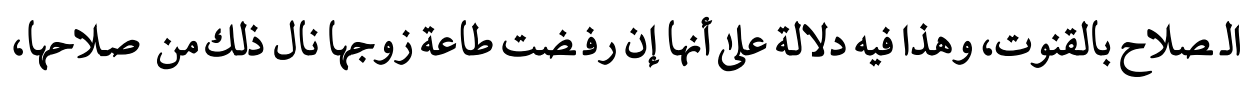

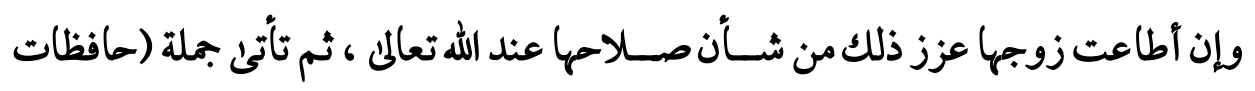

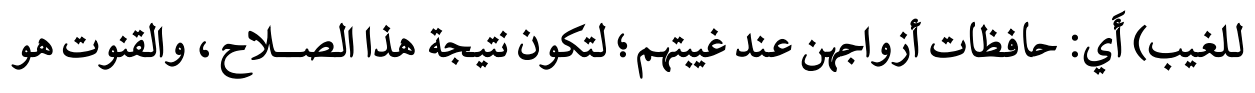
حفظهن لبيوتهن وأزواجهن ، والسر في ترادف مذه الصفات الثلاث دون عطف هو الدلالة

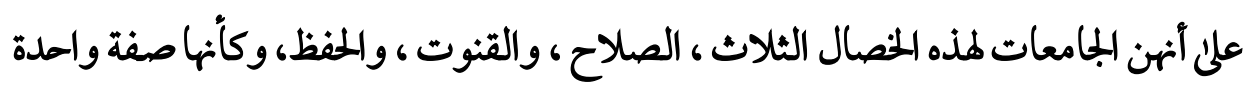

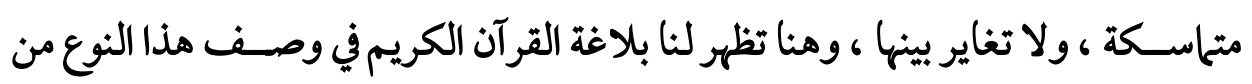

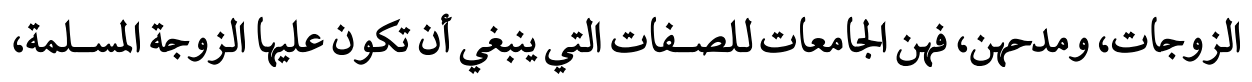

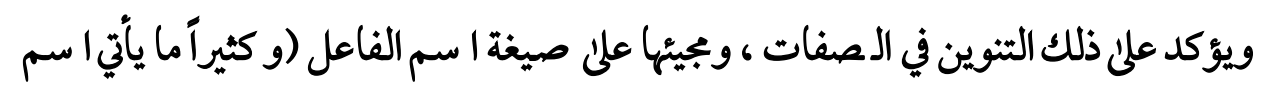

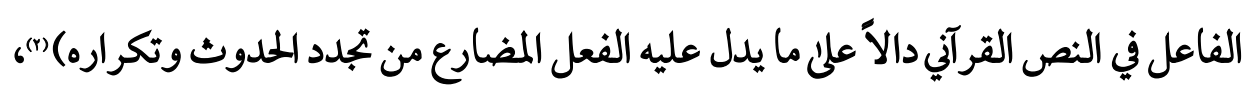
وعلق الله الغيب بالحفظ فقال سبحانه وتعالن: (مافظات للغيب) علئ سـبيل المجاز العقلي؛ لأنه وقته ، فالغيب نفسه لا يمفظ ، ولكنه وقت للحفاظ تحفظ الزوجة زوجها في نفسه وماله

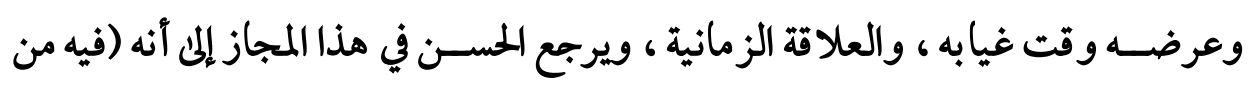

(1) يرابع: المفردات في غريب القرآن لأبئ القاسم المعروف بالراغب الأصفهاني ،تحقيق: صفوان عدنان

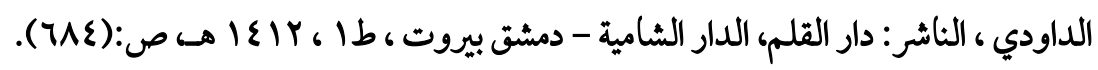

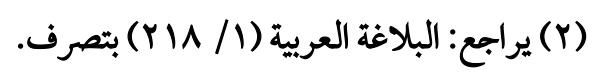


المبالغة، وقوة التأثير ما ليس في غيره) (1) ، وكأنه من شــدة حفظها لأمور زوجها تلبس الحفظ بالوقت نفسه ، و (الباء) في قوله تعاليه (ب) حفظ الله) للملابسة، أي حفظا ملابسا لما حفظ الله

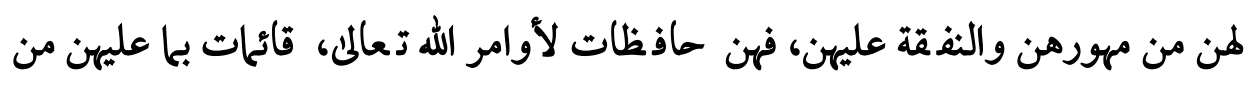

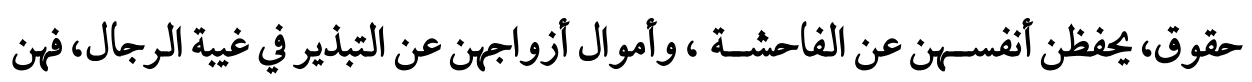

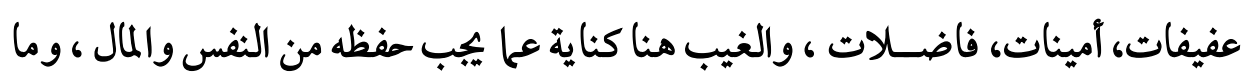

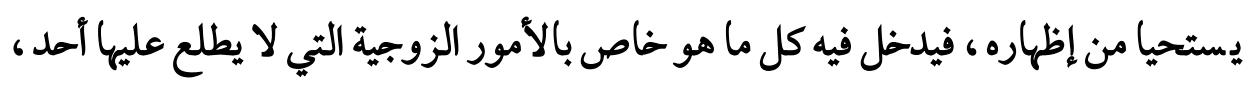

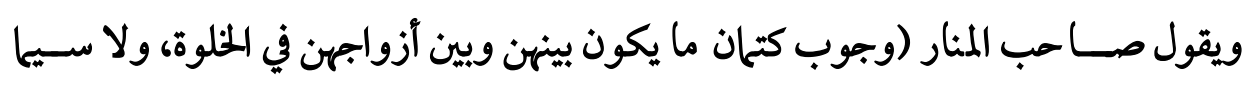
حديث الرفث، فا بالك بحفظ العرض، وعندي أن هذه العبارة هي أبلغ ما في القرآن من دقائق كنا يات النزاهة،... فالانتقال السر-يع من ذكر ذلك الغيب الحفي إلى ذكر الله الجلي، يصر-ف النفس عن التحادي في التفكر فيا يكون وراء الأسـتار من تلك الخفايا والأسرار، وتشغلها بمراقبته عز وجل) (")

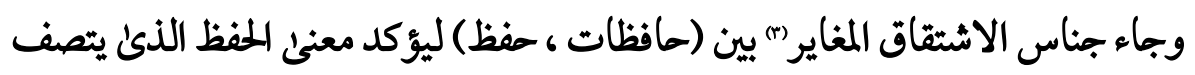
به هؤلاء الصلحات، من خلال التقارب الصوتي بين اللفظين، وتردد حروفه الذئ آفاد

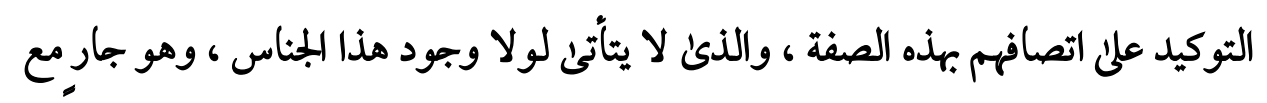

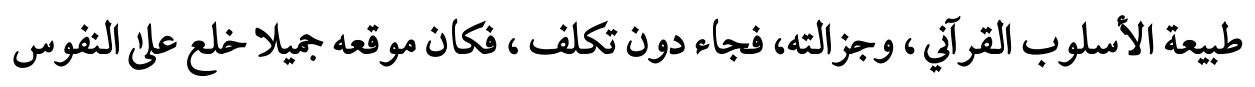

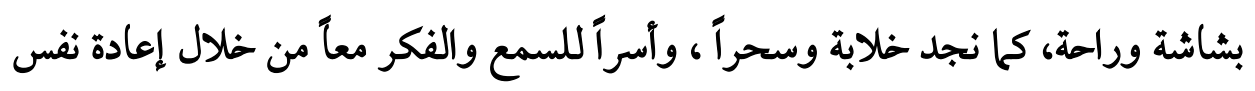

(1) يرابع: البلاغة القرآئة في تفسير الزخشري وأثرها في الدراسات البلاغية د/ محمد محمد أبو موسى، دار الفكر العربي، القاهرة، (10ع).

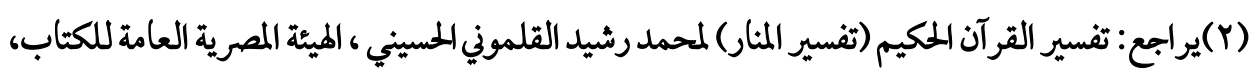

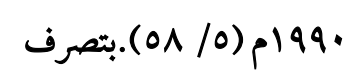

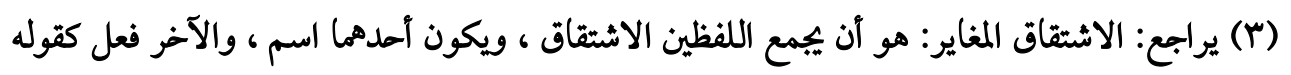

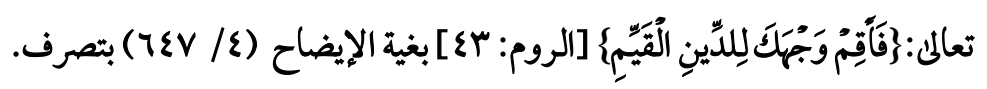


اللفظة، وفي هذا يقول الإمام عبد القاهر :(قد أعادعليك اللفظة كأنه يخدعك عن الفائدة وقد أعطاها، ويوهمك أنه لميزدك وقد أحسن الزيادة ووفاها)(") ، ويدلل علئ عدالة الإسلام، وكأن حفظهن لأزواجهن مرتبط بحفظ الله لمن، وامتدادله . وجاء في الآية الكريمة حذف لدلالة ما قبله عليه، استغني بدلالة الظاهر من الكلام عليه من ونم ذكره، ومعناه: فالصلحات قانتات حافظات للغيب بيا حفظ الله، فأحسِوا إليهن وأصلحوا(")، وهذا من بلاغة القرآن الكريم وإييازه ، والدلالة علن علده، وحرصه على المسارعة في معالجة قضية خلاف الزوجين، فسارع بذكر أمر الناشز حتى يطرح العلاج المناسب، وقال: الإمام عبد القاهر

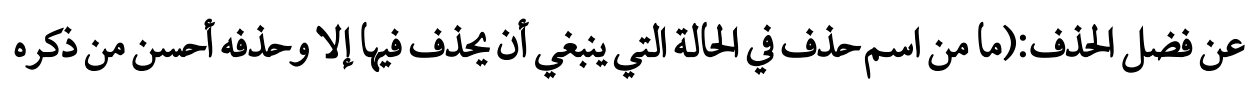

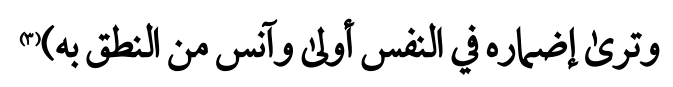
ولما عرف بالصالحات، ومي الفئة الأولى لاستحقاق الإنفاق في اللوازم آتبعه حكم غيرهن، وهي الفئة الثانية وهن الناشزات من الزوجات فقال سبحانه وتعالمي:

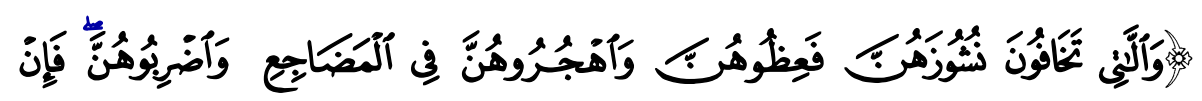

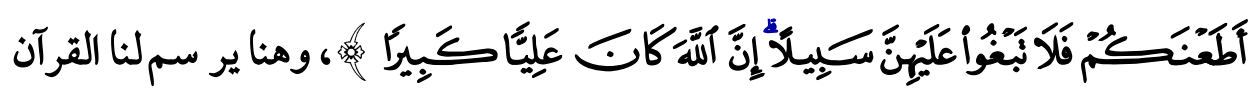

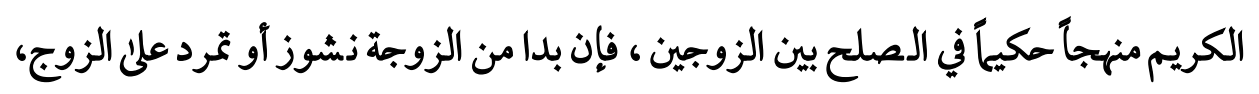

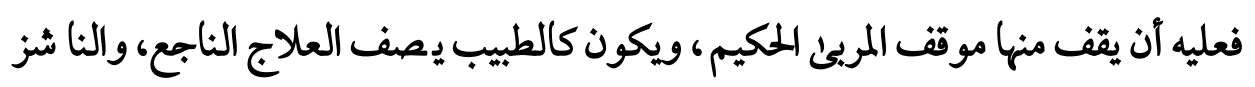

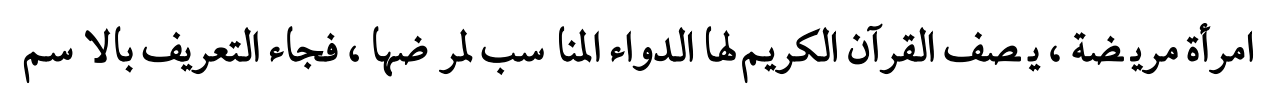

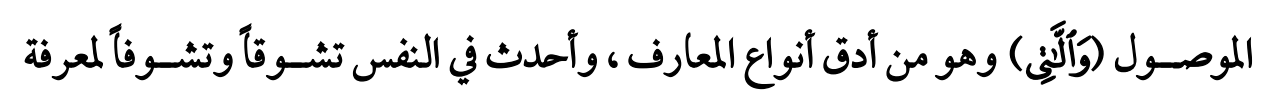

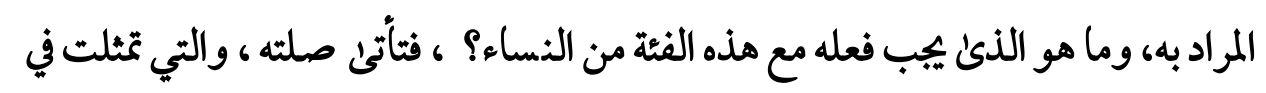

$$
\begin{aligned}
& \text { (1) يراجع: دلاثل الإعجاز ( \& (Y) ) (Y). }
\end{aligned}
$$

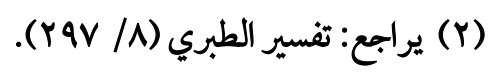

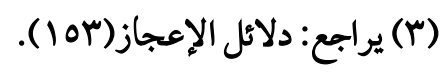


طرق العلاج الثلاث ؛ لتجيب علئ هذا وترد هذا التشوق ، ويقول الإمام السكاكئ:( وأما

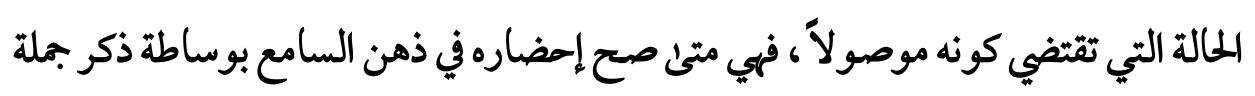

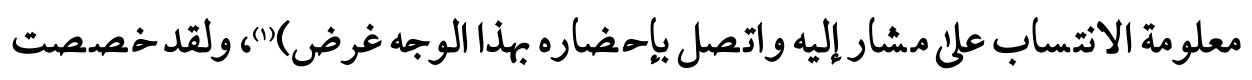

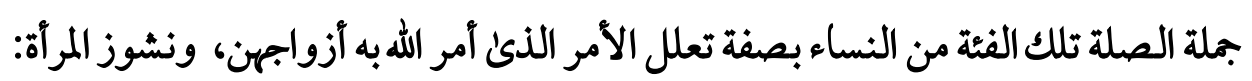

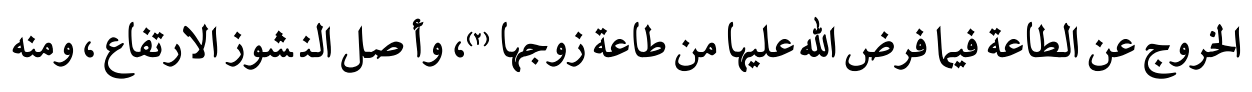

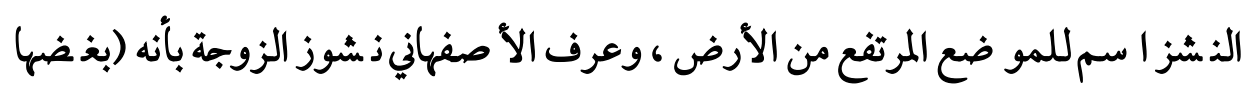

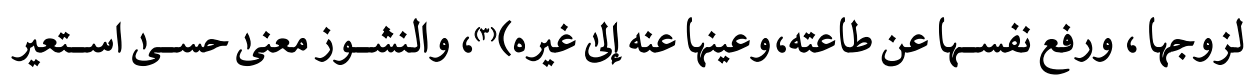
للترفع ، وقدا ستعير (النشوز) للترفع والعصيان ، وا شتق من النشوز (نشوزهن) بمعنى

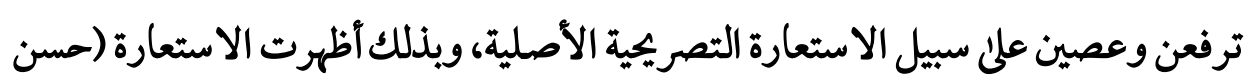

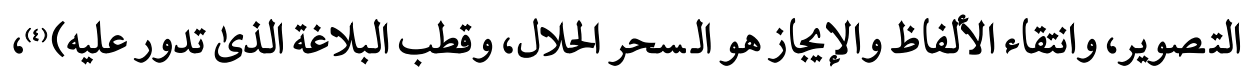

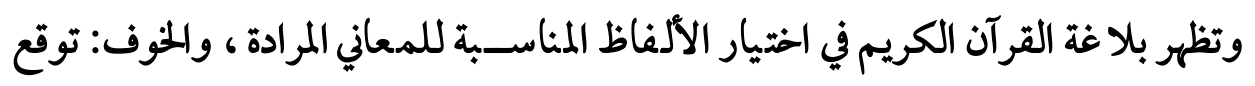

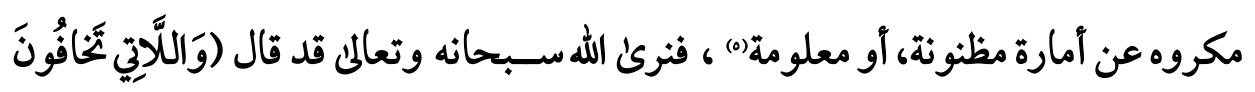

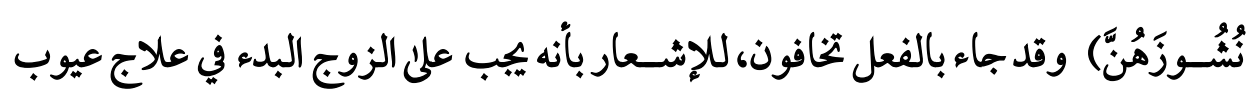

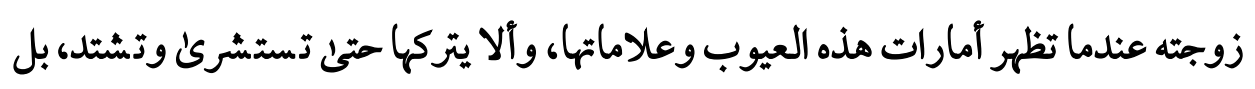

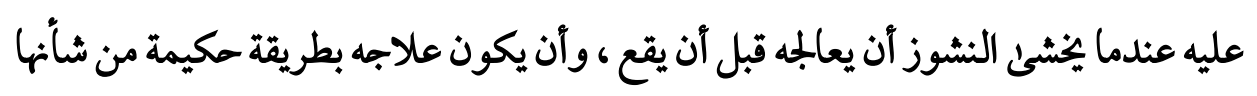

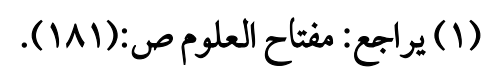

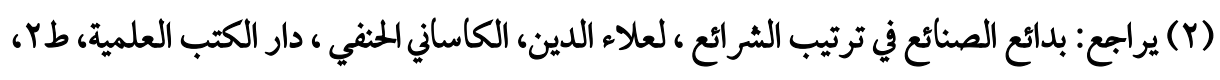

$$
\begin{aligned}
& \text { (T) }
\end{aligned}
$$

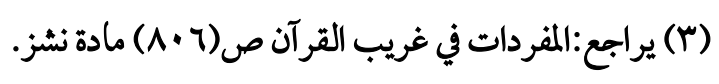

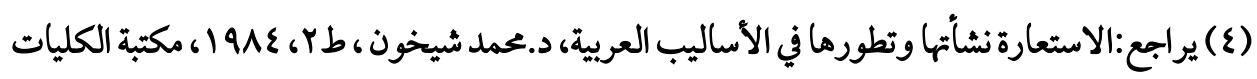

$$
\text { الأزهرية، القاهرة،ص: (•) (11). }
$$

(0) يراجع: المفردات في غريب القرآن ص: ( + (Y). مادة خوف. 
أن تقنع وتفيد، ومن خلال الدلالة اللفظية للفعل (تخافون) يظهر لنا مدئ حرص الإسـلام

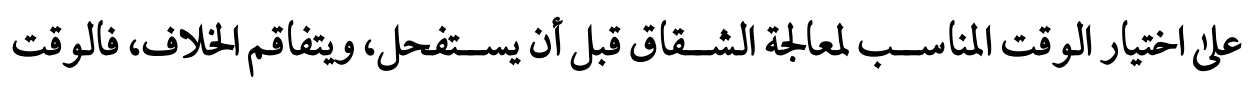
المستحب للوعظ عند خوف النشوز وإن لميقع والموف بمعنى العلم؛ لأن خوف الشيء إنما يكون للعلم بوقوعه ، فجاز أن يوضع مكان يعلم يخاف، فنرئ بعض المفسرين فسر الخوف، لئل

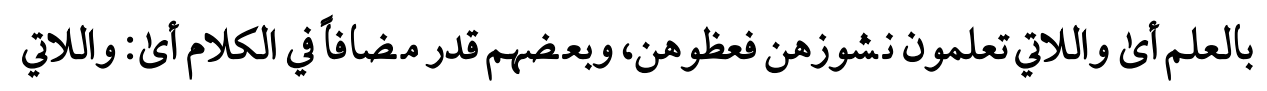
تخافون دوام نشـوزهن، فعظوهن واهجروهن في المضـاجع، وبعضهـم قدر معطوفا محذوفاً أي: واللاتي تخافون نشوزهن ونشزن، فعظوهن واهجروهن فئن في المضاجع (1).

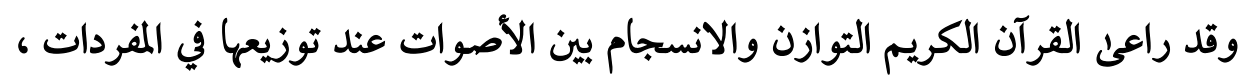

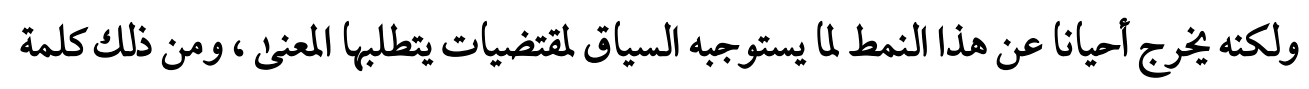
(نشوز) التي بين أيدينا، وهئ من الألفاظ التي تحس حال النطق بها بشيء من الصعوبة ، وأصل

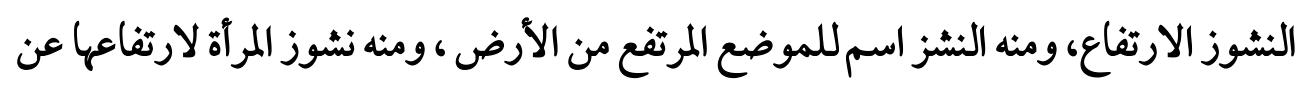

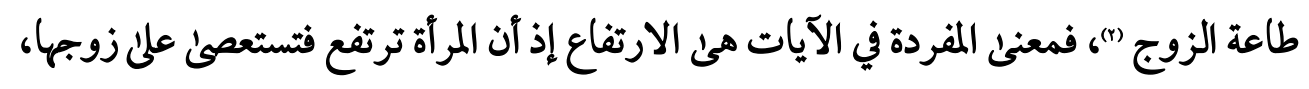

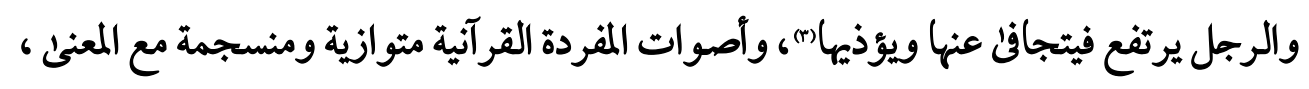

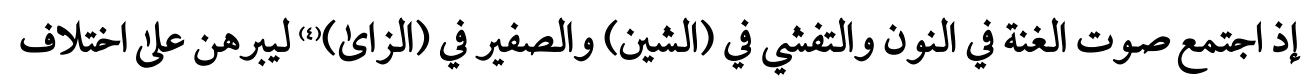

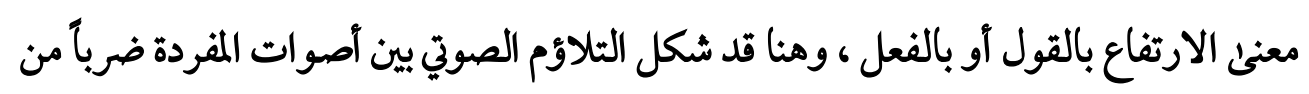

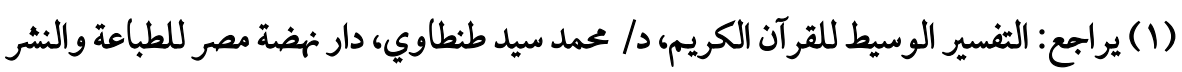

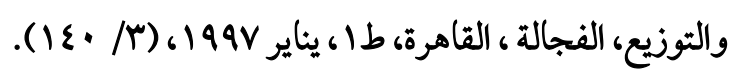

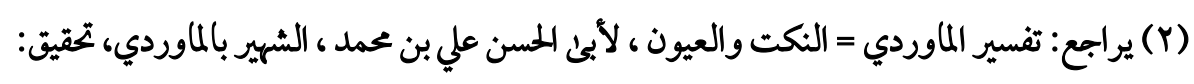

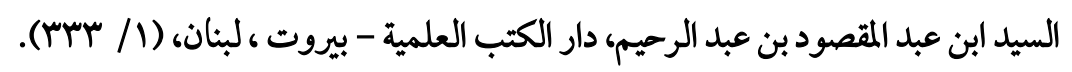

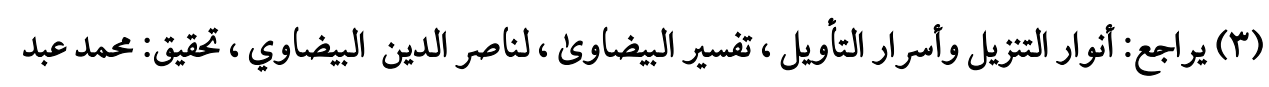

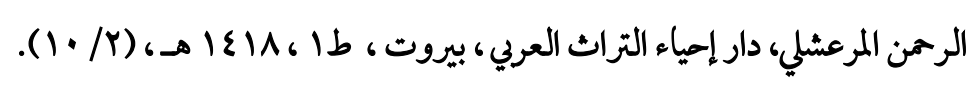

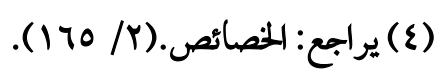


التناغم الذئ جعل المفردة توحئ بدلالتها من خلال الأصوات المكونة لها ، فهذا الجرس القوئ للمفردة ، والصعوبة الماصلة في التلفظ يوحلى بصعوبة الموقف في الآيات القرآية عند استعلاء الزوجة على زوجها ما يؤنئ إلى هدم الكيان الأسرئ الذئ يدعو الإسلام إلى إقامته والمفاظ على لئل ديمومته .

و تبدأ الآ يات الكريمة بتقديم طرق العلاج لنشــوز الزو جة فيقول جل

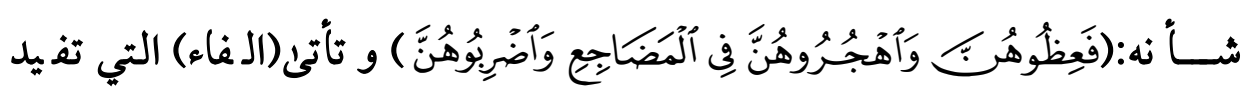
التعقيب، فلأمر ليس فيه تراخ بعد ظهور علامات النشــوز والعصـيان ، فعلن الأزواج

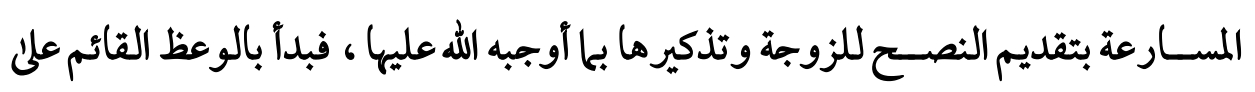

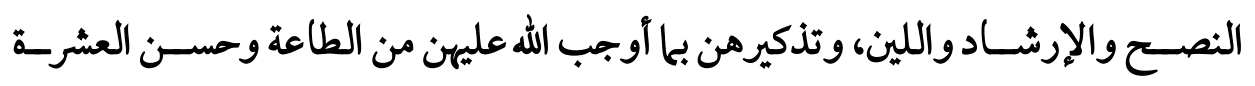

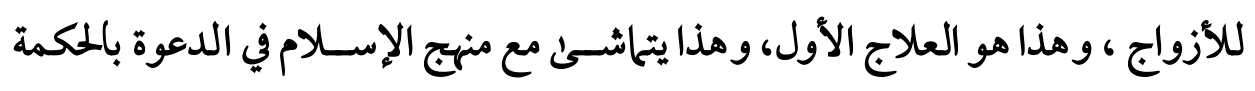

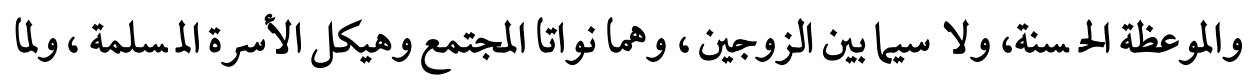

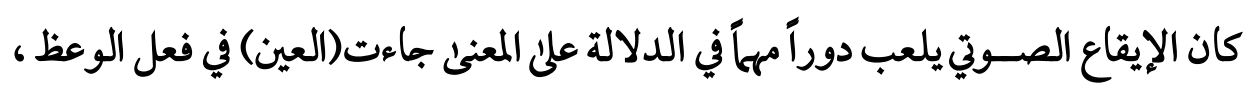

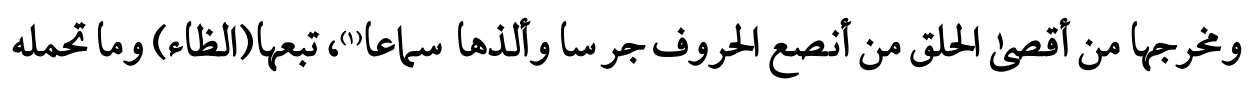

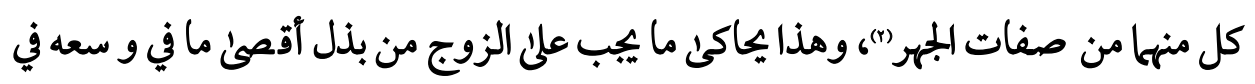

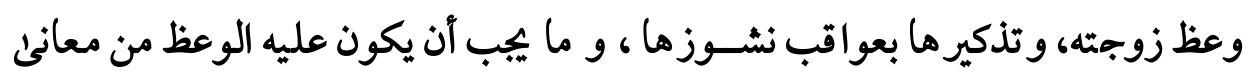

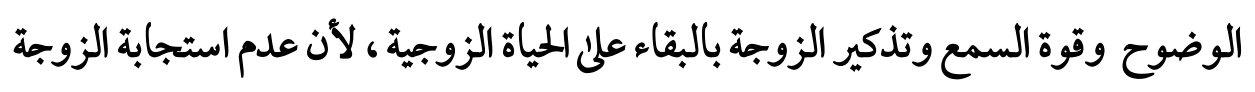

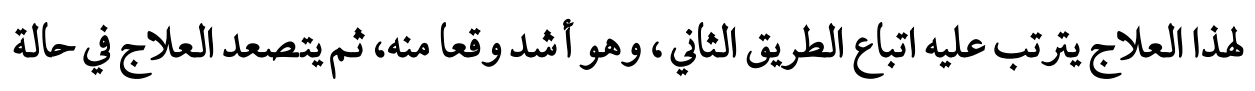

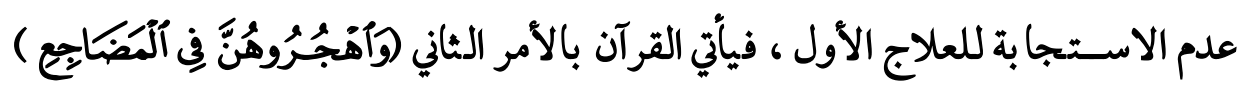

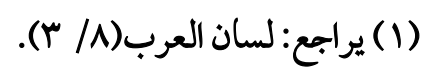

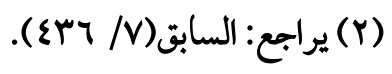




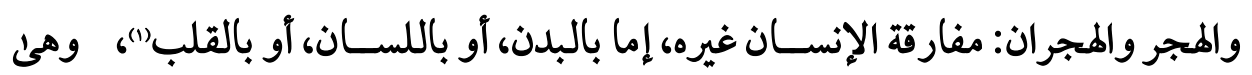

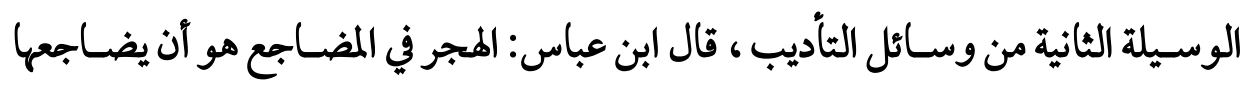

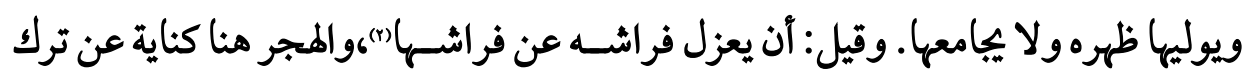

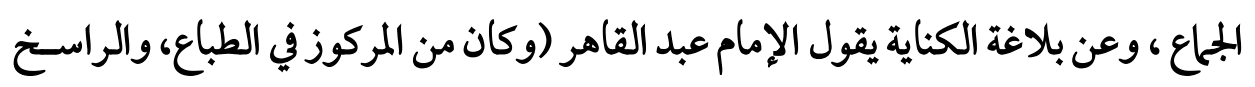

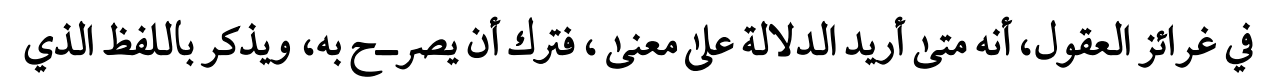

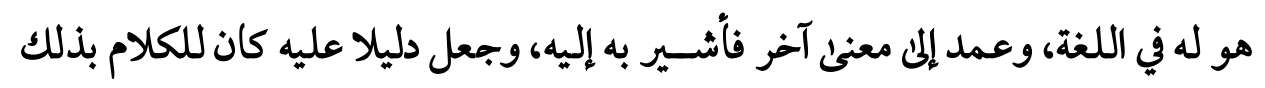

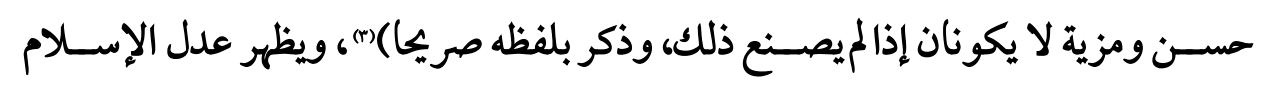
وو سطيته في حر صه علن القضاء على الشقاق بطريقة بعيدة عن الشدة حتى يعود كل منها

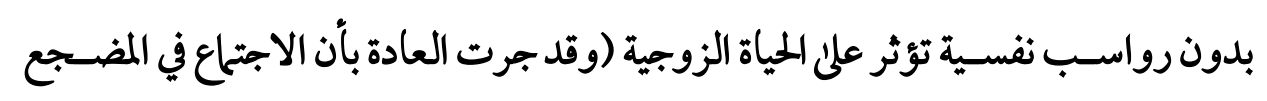

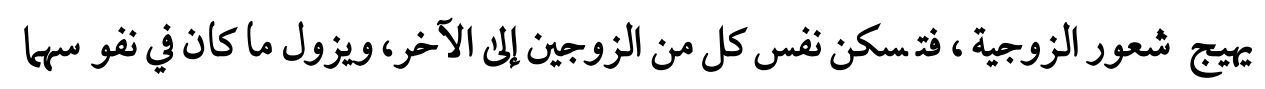

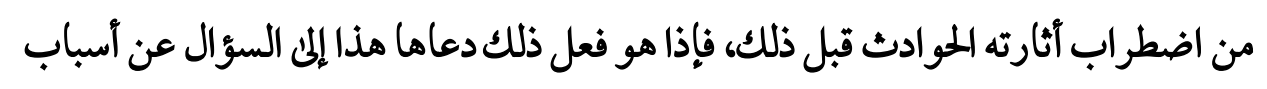

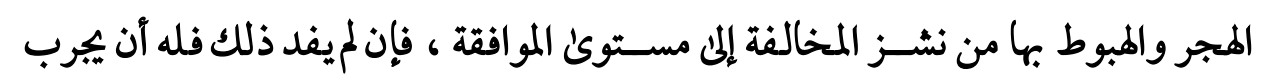

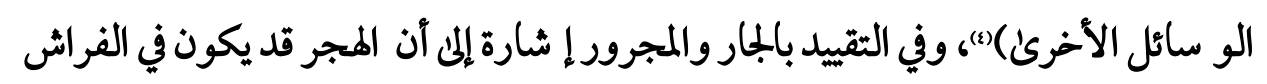

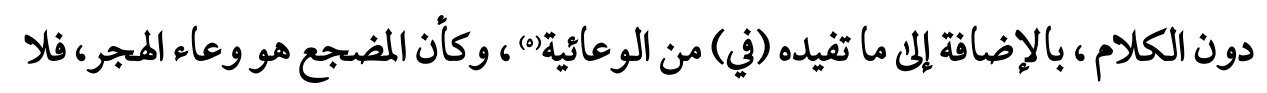

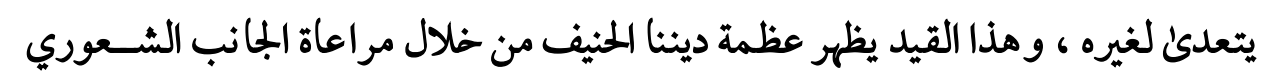

$$
\text { (1) يراجع:المفردات في غريب القرآن ص:(YrYA) مادة هجر. }
$$

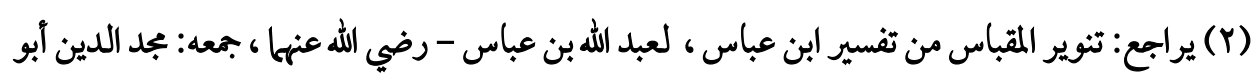

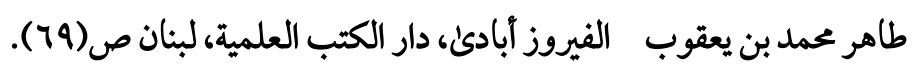

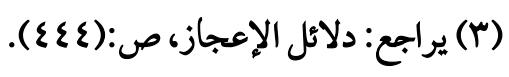

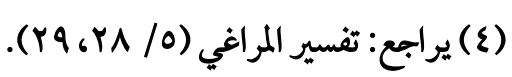

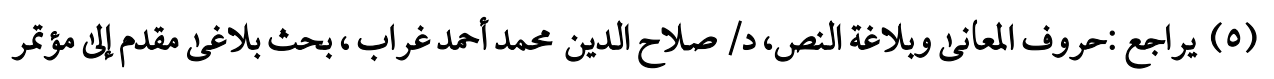

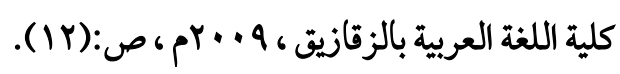


للأبناء ؛ حتى لا ينعكس ذلك سـلباً عليهم، والعلاج بالهجر جاءعلى سـبيل التدرج من

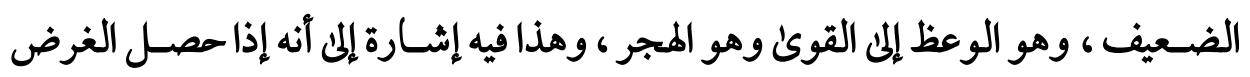

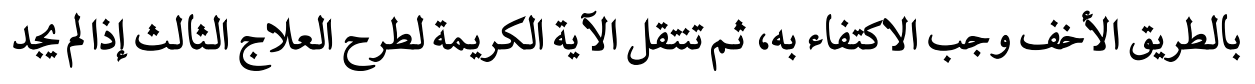

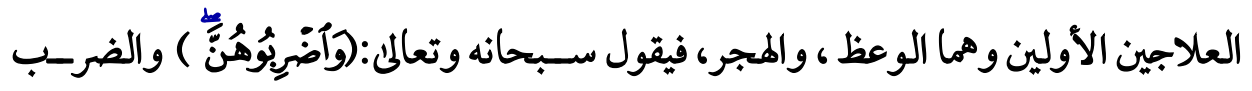

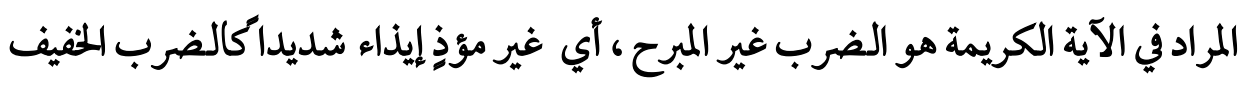

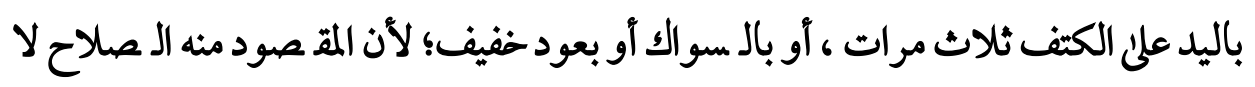

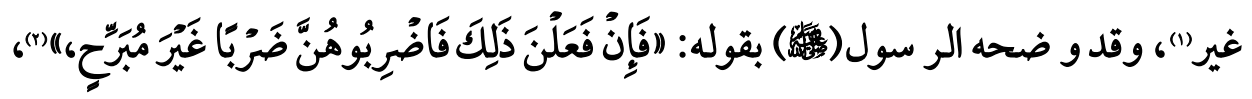

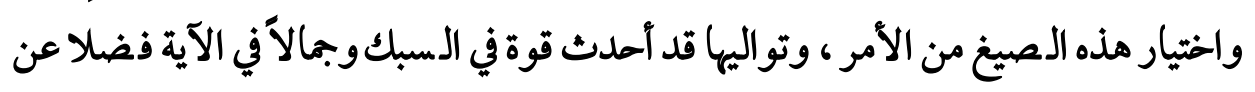

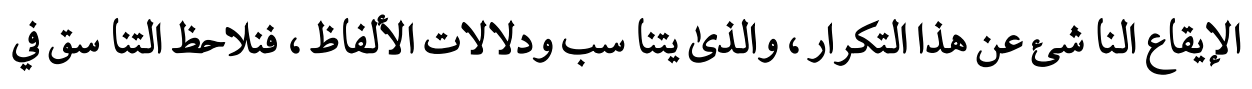

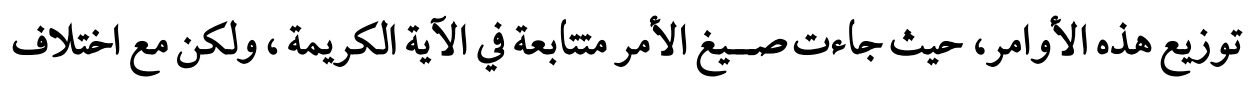

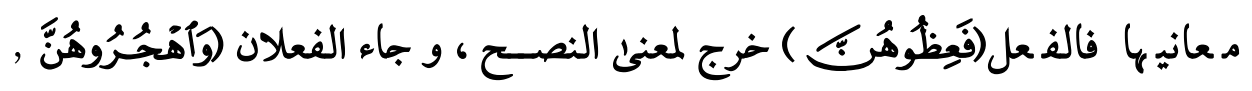

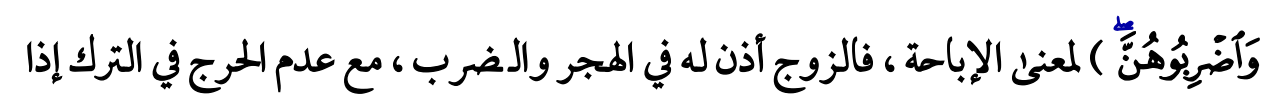
لم يضطر لذلك وارتدعت الزوجة من المرحلة الأولى وهئ الوعظ.

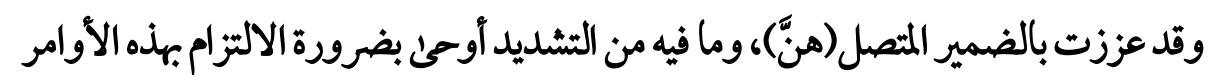
كل في وقته، وهذا يتناسب مع قوة المعنى، فالأسلوب القرآئ يرشد الزوج للقيام بالمحاولات والطرق المتعددة بتعدد الصيغ حرصاً منه على التقويم والمعللجة قبل تفاقم الثلاف. وهنا تظهر وسطية الإسلام في أرقى معانيها والثدرج في المعللجة تبعاً لتصعيد حالة النشوز حيث بدأت الآية بطرح العلاج نفسياً من خلال محاورات وعظيه حفاظاً على بقاء الحياة

(1) يرابع: التفسير المنير في العقيدة والشريعة والمنجج ، للدكتور: وهبة بن مصطفي الزهيلي، دار الفكر

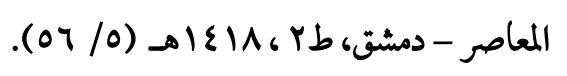

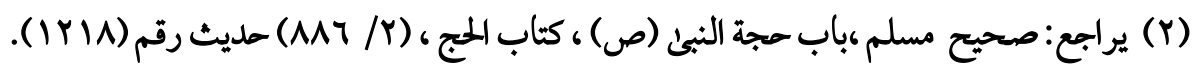


الزوجية، ثم المجر ويكون فيه إنذار للمرآة ، ثم تأتئ المرحلة الثالثة ، والتي فيها ترقي مع ما

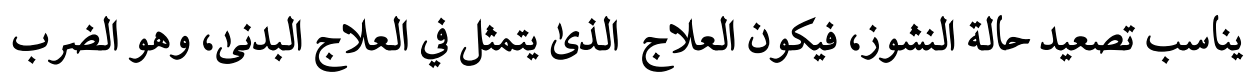

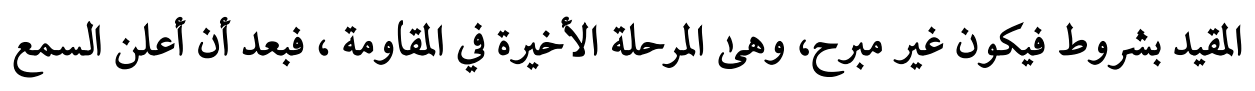

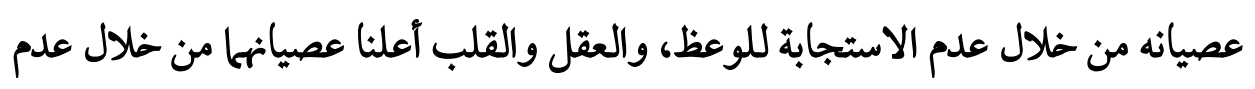
الاستجابة للهجر، جاء الإسلام ليعلن عن طريق أسمع وأوقع، وهو حسى يتمثل في تنبيه

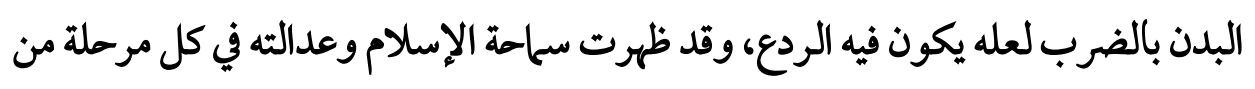

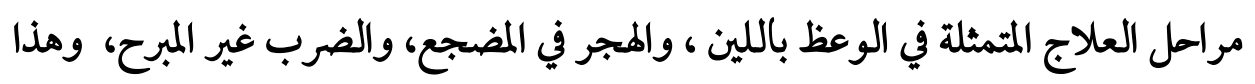
فيه إثارة إلى وسطية الإسلام وعدالته حتى في حال الحلاف، فالضرب الذابل الذي أذن فيه الإسلام

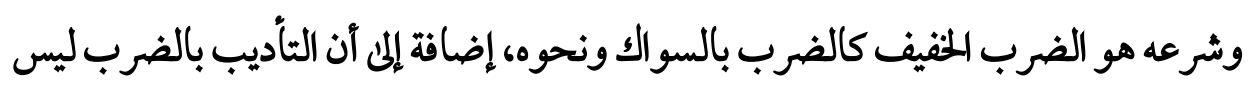
فرضاً ملزما، ولكنه أمر مباح، والأفضل تركه، وظاهر اللفظ يدل على الترتيب، والآية وردت علن سبيل التدرج من الضعيف إلى القوي إلى الأقوئ، وذلك جار مجرئ التصريح

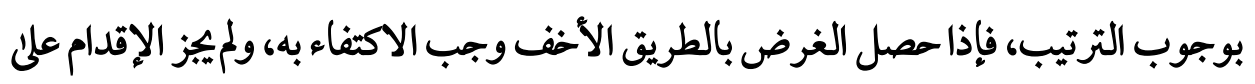
الطريق الأشد (1) ، ثم يأتي النظم القرآي لييين لنا مظهر آخر من وسطية دينتا الحنيف من خلال

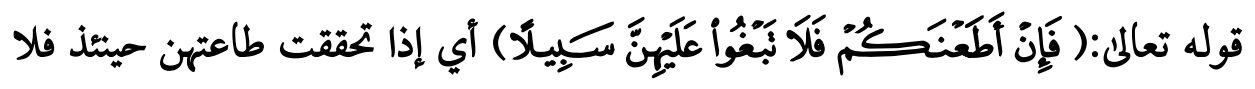

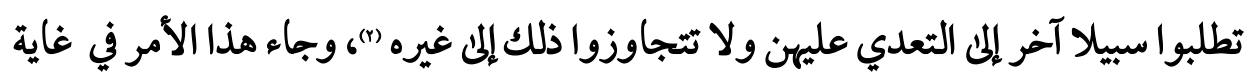

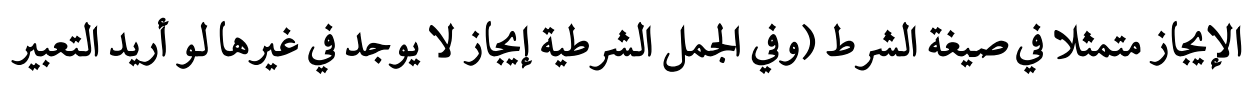
عن مضمونها بجمل غير شرطية)("). وهذا يدل علن أنه إذا تحققت الطاعة من قبل الزوجة، فيها" فلا سبيل للتعنت والبغي، والبغي:

$$
\begin{aligned}
& \text { (1) يراجع: روائع البيان تفسير آيات الأحكام (I/ • (1) . } \\
& \text { (Y) يراجع: التفسير الكبير (• / / / (Yr). }
\end{aligned}
$$

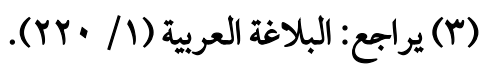


هو طلب تجاوز الاقتصـاد فيا يتحرىن، تجاوزه أملميتجاوزه، يقال: بغيت الشي_: إذا طلبت

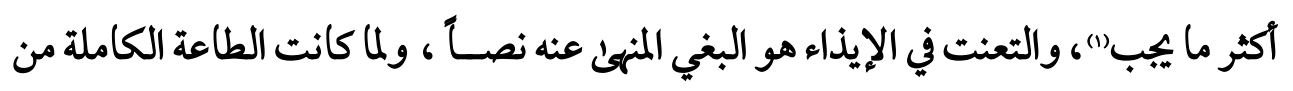

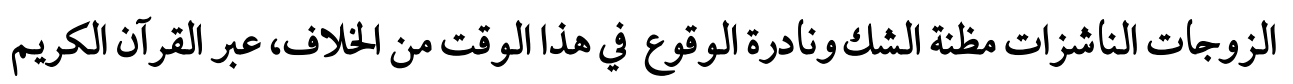
بأداة الشرط (إن) التي تدل على الأمر غير المقطوع بوقوعه، دون (إذا) فكان التعبير ب---_(إن)

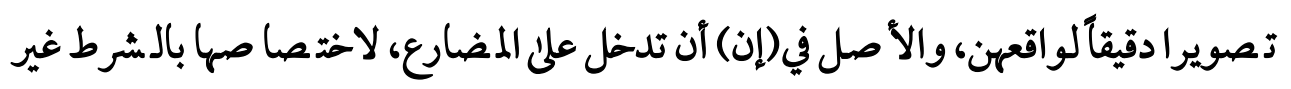

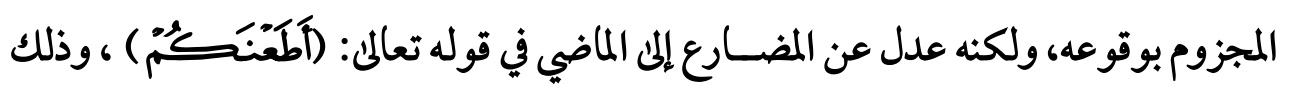
إبراز غير اللحاصل الذئ يحدث في المستقبل في معرض الحا صل الذئ وقع في الملاضي ، وتحققنا من وقوعه ، وكأن الطاعة حاصلة وواقعة ، وذلك لإظهار الرغبة القوية والتفاؤل في تحقق هذه

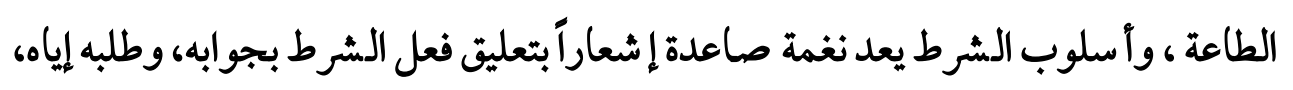

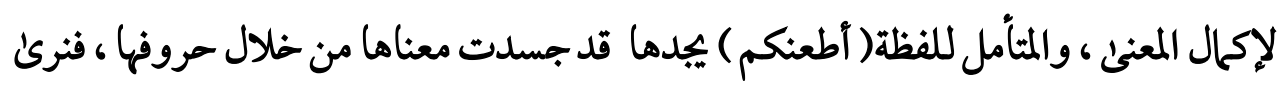

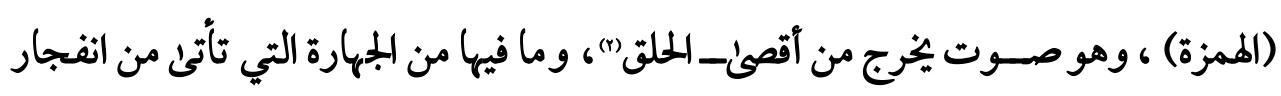

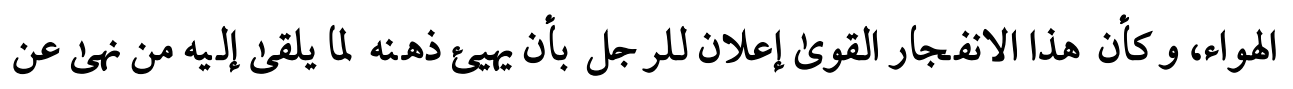

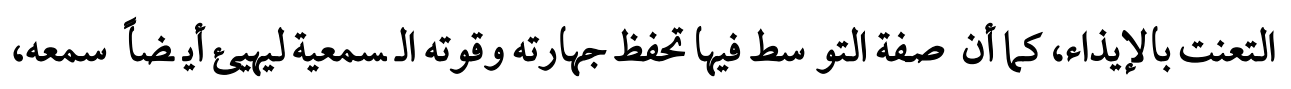

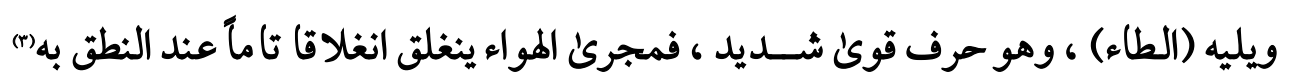

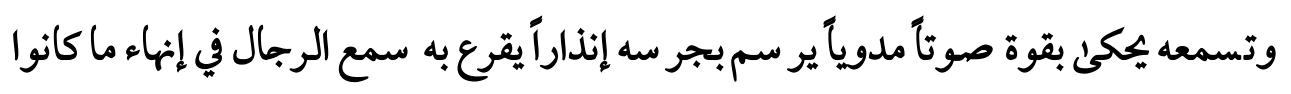

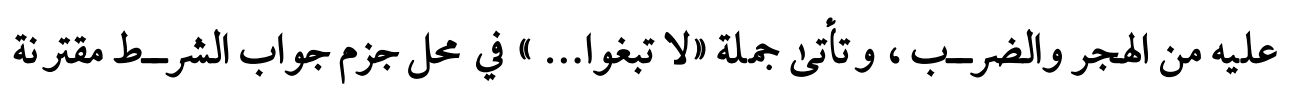

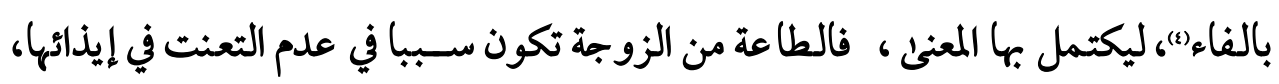

$$
\text { (1) يراجع: المفردات في غريب القرآن ص: (1 (1/1) مادة (بغلى). }
$$

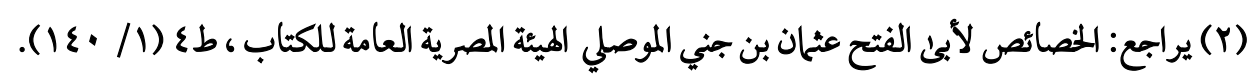

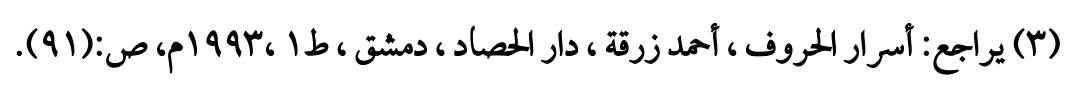

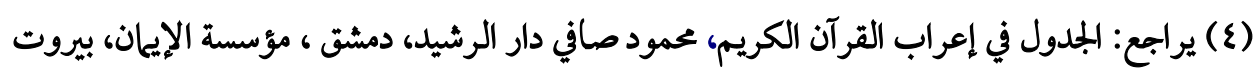


فكلاهما متعلق بالآخر ، و هذا يؤ كد علنى التحذير من البطش بالزوجة إذا أعلنت طاعتها ، واسـتفيد من صـيغة النهي التكليف الإلزامي بالترك وعدم الفعل، ويحمل في طياته معانئ مئل التحذير ، بالإضافة إلى أن النهى عن البغي والتعنت جاء بــ(لا) وما فيها من استطالة في النطق

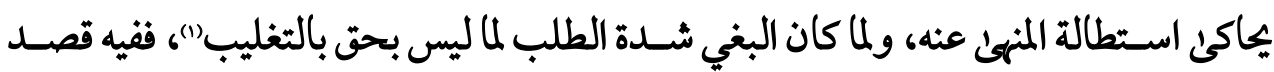

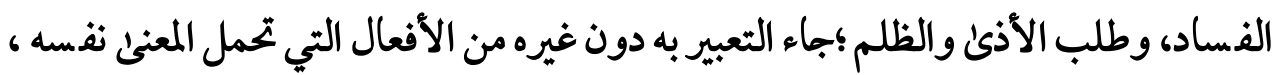
وعضــد هذا المعنى حرف الجر (علن) الذئ يفيد الاستعلاء، واتصـاله بالضـمير(هن) المتعلق بالفعل (تبغوا) ، وتظهر دقة القرآن الكريم في تصــير التعنت بالعقاب المنهئ عنه من خلال

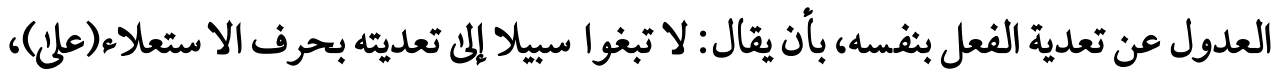

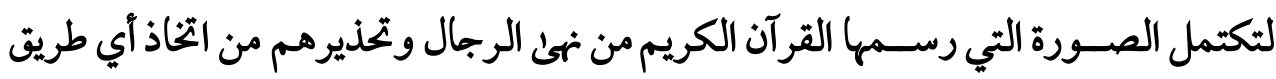
للاسـتعلاء به عليهن في الإيذاء ، وحرف الجر (علم) موضـوع للاستعلاء المسسئ، ومدخولها

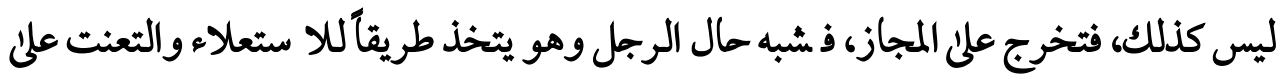
المرآة بحال من اعتلي شيء وركبه، وتمكن من أزمته، بجامع التمكن والا ستقرار، ثم ا ستعرت

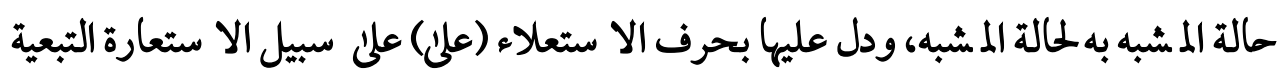
التمثيلية ، ويأتي النهى الربانيللزوج بألا يتخذأي سبب ليتمكن به من ايذاء زوجته ، و يمكن الته القول بأنه شبه الطريق الذئ يتخذه الرجل للتعنت بالمستعلي عليه الحسىي، ثم استعيرت (علني)

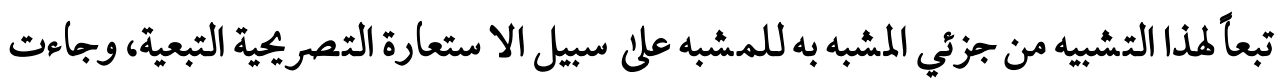
كلمة (سـبيلا) نكرة لتعضــد هذا المعنى وتؤكد علئ النهن، ولتفيد التقليل والتحقير ، أي: لا

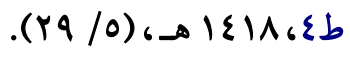

(1) يرابع: الفروق اللغوية لأبنى هلال المسن بن عبد الله العسكري، تاه/ محمد إبراهيم سليم، دار القلم

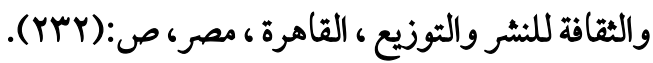


تتخذوا أي طريق لإيذائهن حتى ولو كان يسيراً.

وجاءت المقابلة بين النشوز مع طرق علاجه، ويين الطاعة مع النهئ عن البغي في هذه الآية

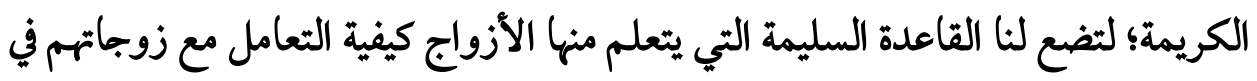

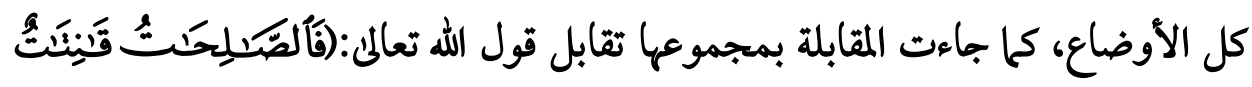

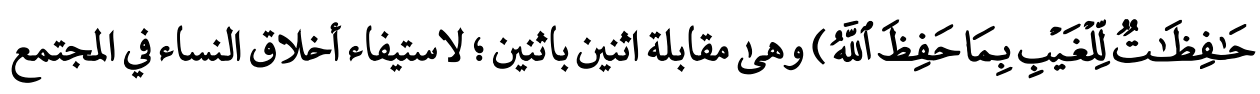
المسلم مع تغليب صفة الصلاح فيهن ، وجعل صورة النشوز محدودة معالجة.

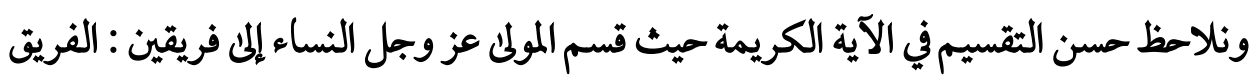

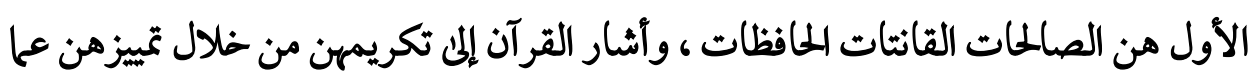

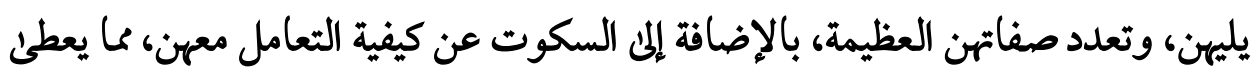

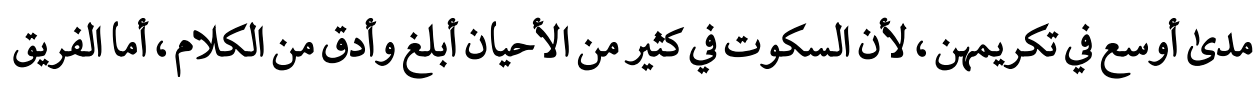

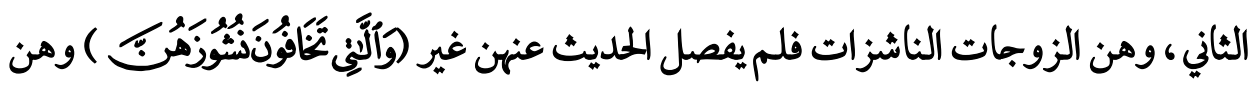
على نقيض الفريق الأول لذلك لم يعدد لمن صفات سيئة تقابل الصفات الحسنة التي ذكرت في جانب الفريق الأول، لذلك اقتضت مكمة التشريع سرعة طرح العلاج لهذا الفريق، وذكر

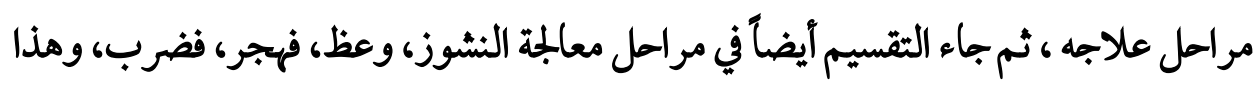
كله حسن تقسيم بعد التفريق الرائع الذئ قسم فيه الإسلام الزوجات إلى قسمين لا ثالث

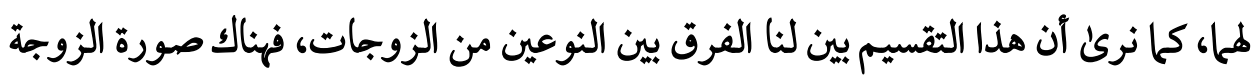

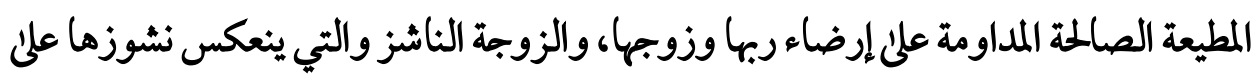

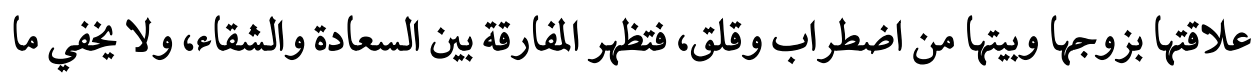

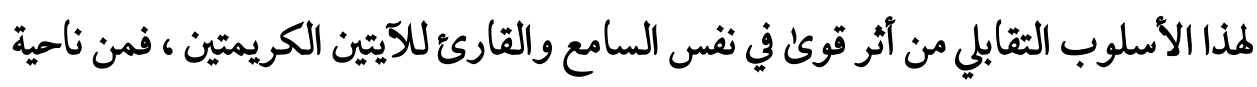
اللفظ أنتج لنا النص نوعين من الإيقاع، الأول: هادئ يتناسب وحال الزوجة الصالحة ، وما

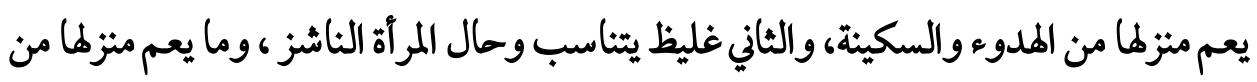


عدم استقرار ، ومن ثم (تكون المقابلة، وما يشبه النقيض ليزداد المعنى بها وضوحا))"()، والله

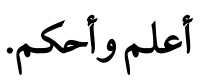

ومن وجوه إعجاز القرآن الكريم، وإيجازه الفواصل ، والتي عرفها الباقلاني بأنها(حروف

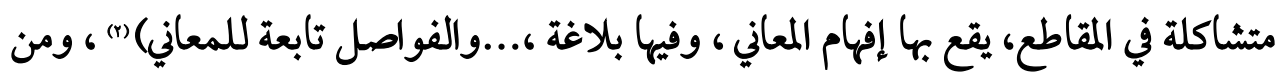
اللصائص الأسلوبية الرائعة في الآية الكريمة، والتي تؤكد معنى العدل والإنصاف الذئ تدعو بهو

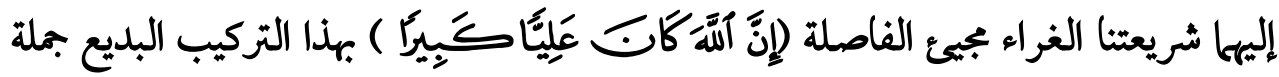
اسمية والمسند إليه لفظ الجلالة ، ودخلت عليه (كان) الناسخة مقترنة بـ (إن) المؤكدة وهذا غاية التأكيد، بالإضافة إلى التعظيم الذئ يجمله لفظ الملالة ما جعل المعاني التي تحملها الآية الكريمة مؤكدة، فضلاً عن صيغة المبالغة التي جاءت عليها ماتان الصفتان ، وتذييل الآية الكريمة بهاتين الصفتين تتفقان ومعنى الآية الكريمة ، حيث يقول الإمام الرازي (وذكر هاتين الصفتين في هذا

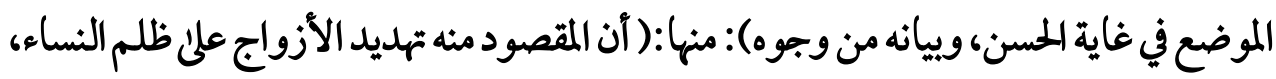

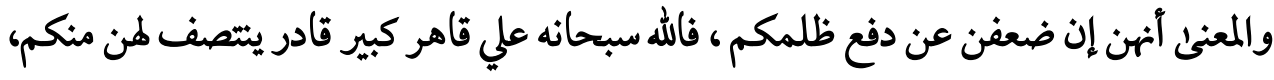
فلا تغتروا بكونكم أكبر درجة منهن، والثاني: لا تبغوا عليهن إذا أطعنكم لعلو أيديكم، فإن الله

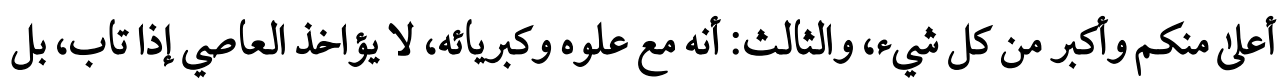
يغفر له ، فإذا تابت المرآة عن نشوزها ، فأنتم أولى بأن تقبلوا توبتها وتتركوا معاقبتها) (ه)، فضلاً عن أنه تعليل للنهئ عن البغي ، وفيه تنبيه علن ضرورة خفض الجناح وتواضع الزوج إذا أعلنت

(1) يرابع: البناء الفني للصورة الأدبية عثد ابن الرومي ، د/ على علن صبح ، مطبعة الأمانة ، طا،

$$
\text { (Y) }
$$

(Y) يرابع: إعجاز القرآن ، لأبن بكر الباقلاني، تحقيق: السيد أحمدصقر ، دار المعارف مصر ، طه، (

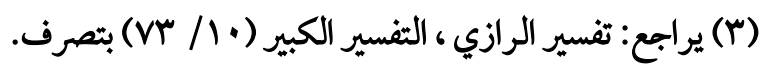


الزوجة طاعتها، ويذلك جاءت الفاصلة مناسبة للمعاني التي اشتملت عليها الآية الكريمة.

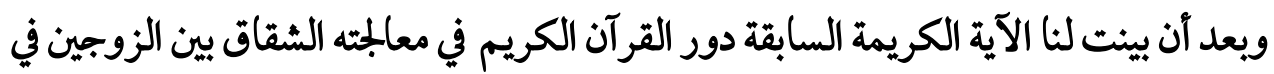

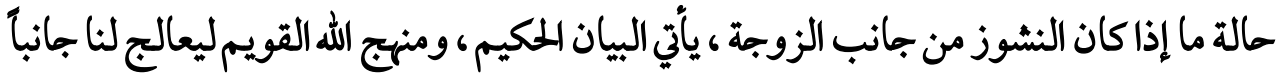

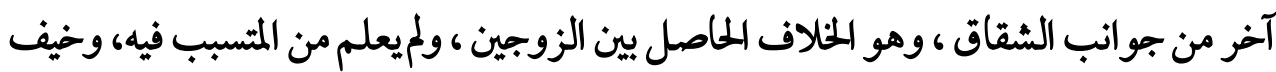

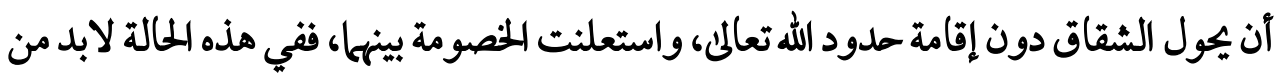

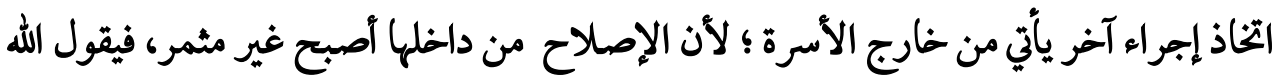

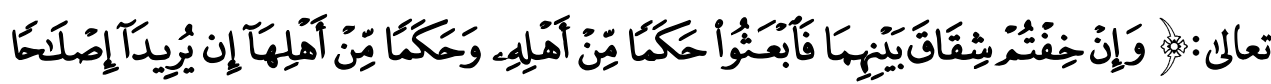

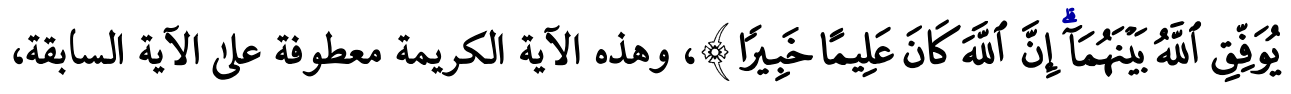

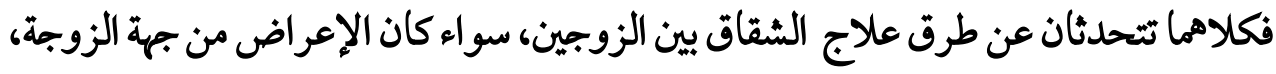

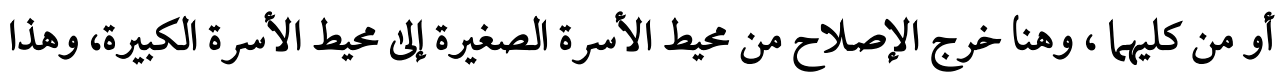

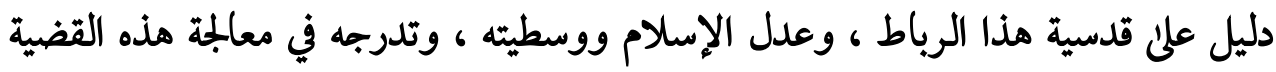

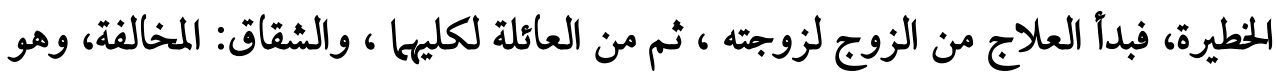

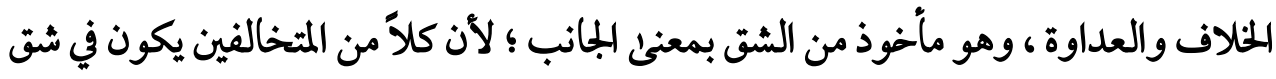

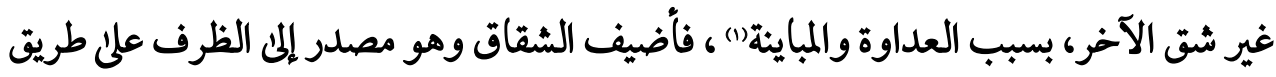

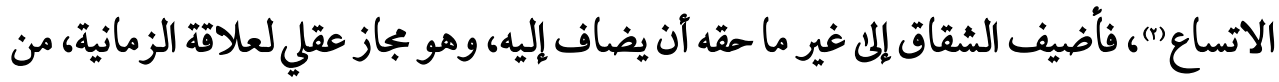

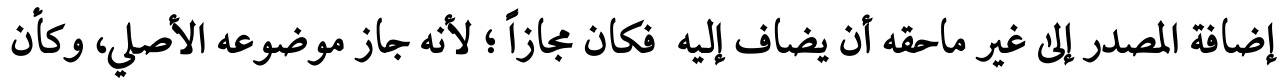

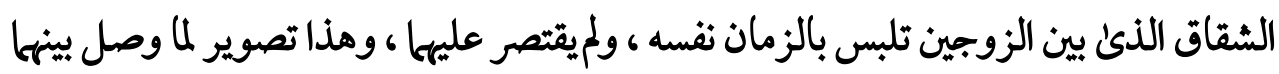

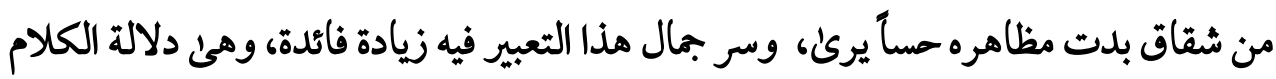

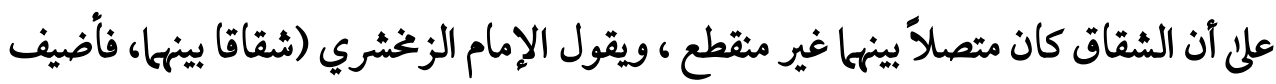

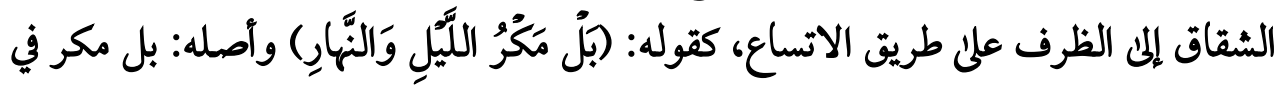

$$
\text { (1) يراجع: روائع البيان تفسير آيات الأمكام (1/ ع7 ع ). }
$$

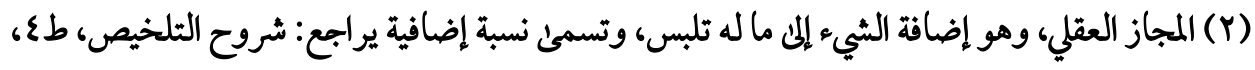

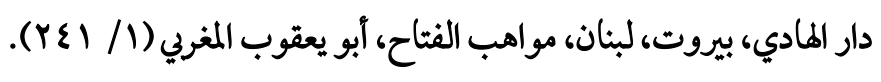


الليل والنهار، أو علن آن جعل اليين مشاقا والليل والنهار ماكرين) (1)، كما جاءت حروف كلمة

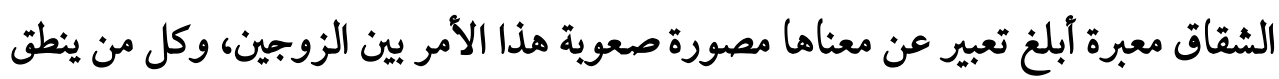

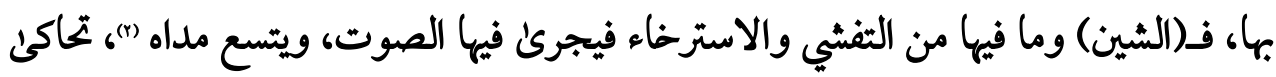

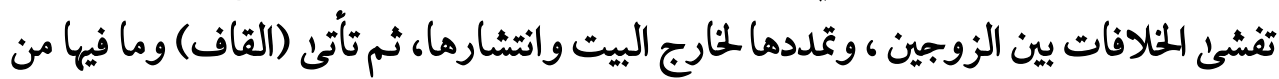

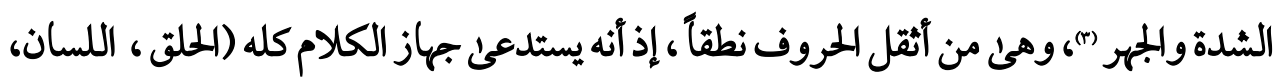

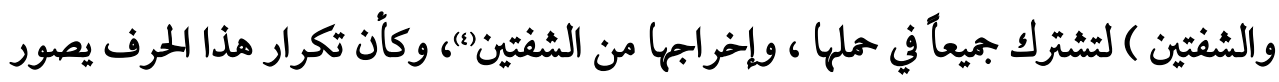

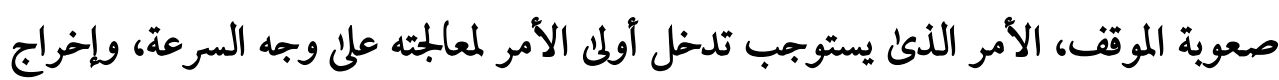

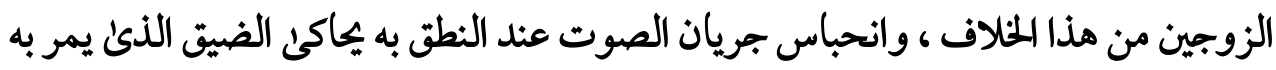

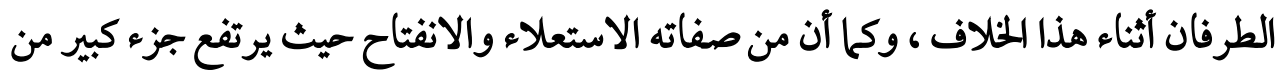

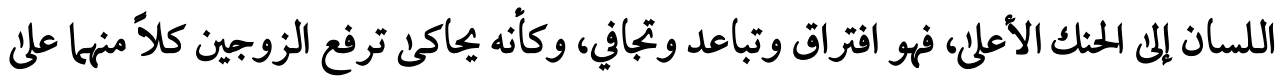

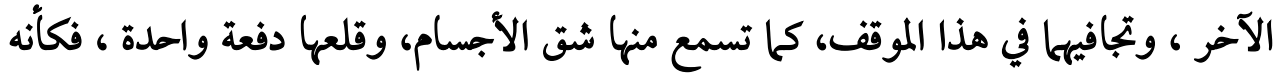

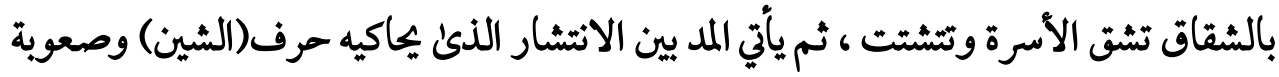

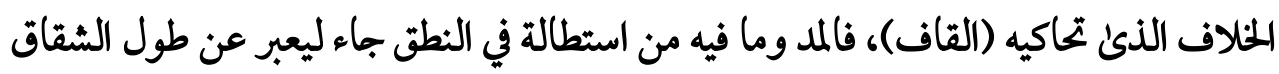

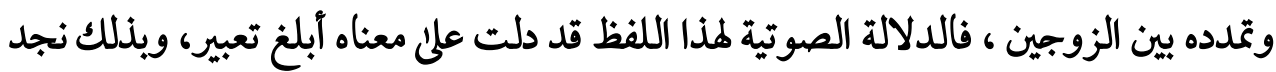

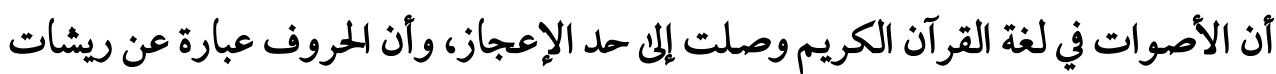

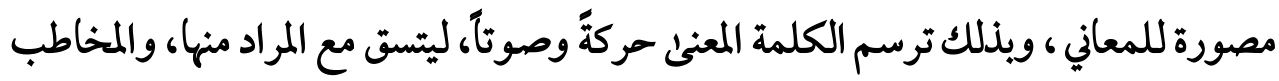

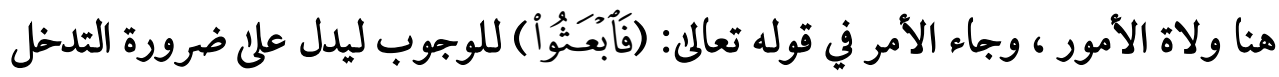

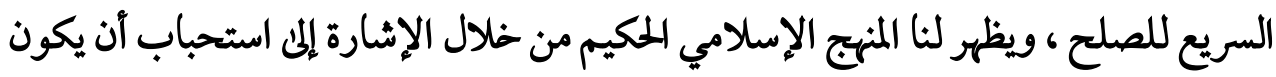

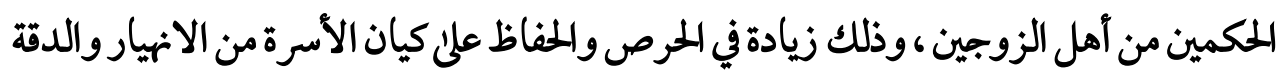

$$
\begin{aligned}
& \text { (1) يراجع: الكشاف عن حقائق غوامض التنزيل (1/ 1 م0). } \\
& \text { (Y) يراجع: الخصائص (Y) (Y) (170). }
\end{aligned}
$$

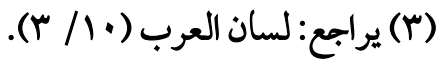

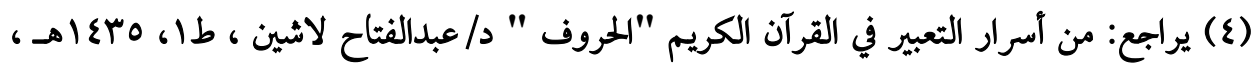

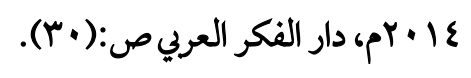


في المعالجة ، فلم يأت لفظ القرآن الكريم مقتصراً على(ابعثو احكمين) ولكنه جاء بالإطناب في

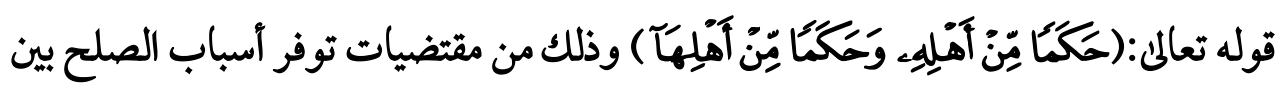

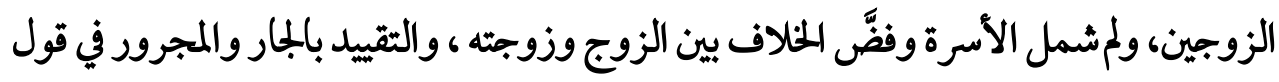

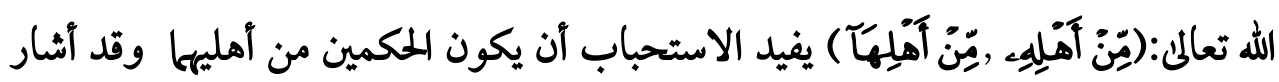

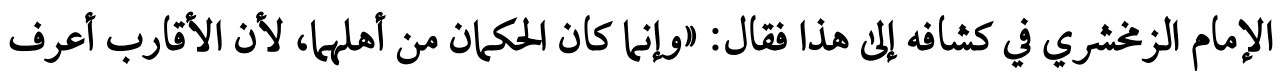

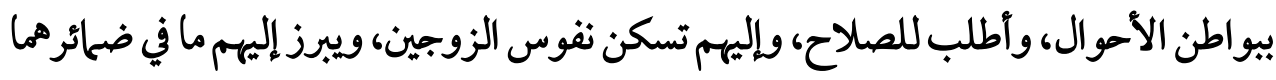

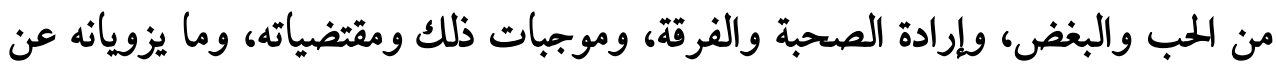

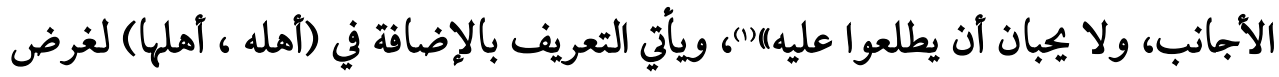

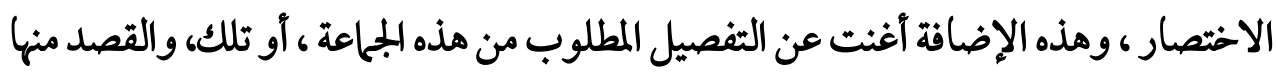

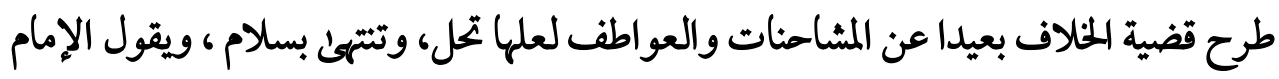

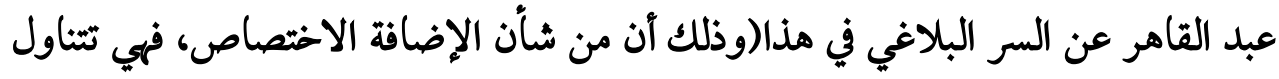

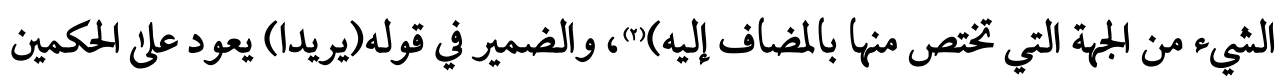

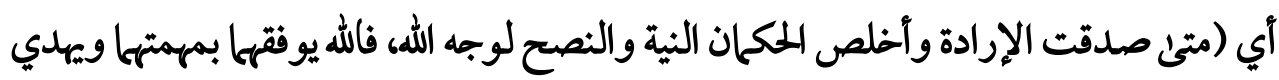

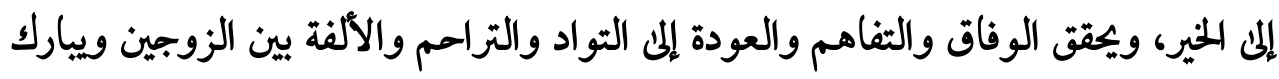

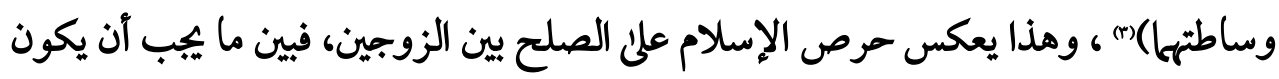

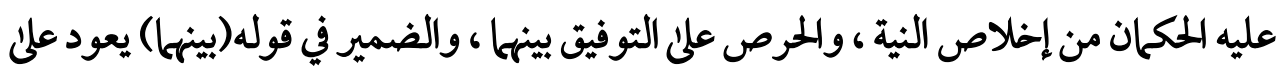

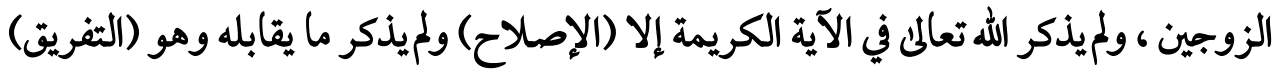

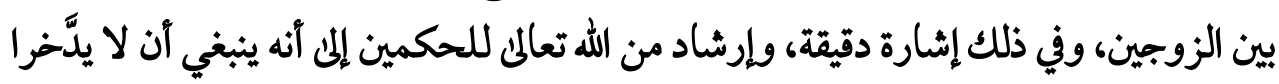

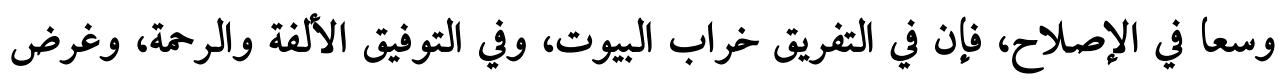

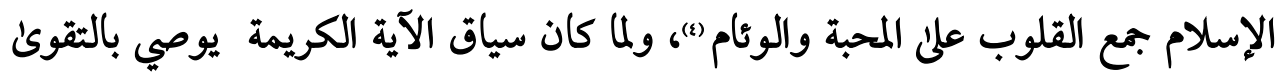

$$
\begin{aligned}
& \text { (1) يراجع: الكشاف (1/ 1 10). } \\
& \text { (Y) يراجع: دلاثل الإعجاز (I/ بآr) }
\end{aligned}
$$

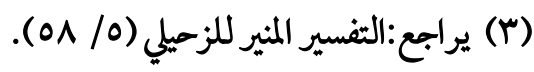

$$
\begin{aligned}
& \text { (ع) يراجع: روائع البيان تفسير آيات الأمكام (I / ل ع ع ). }
\end{aligned}
$$


والإخلاص في الصلح بين الزوجين ، وعدم الانحياز لأحدهما، واتباع الموئ حتى ينتهي النزاع

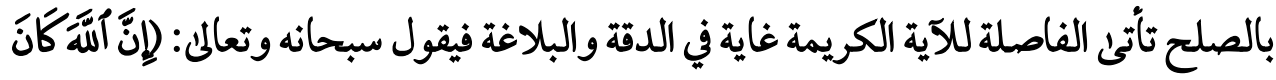

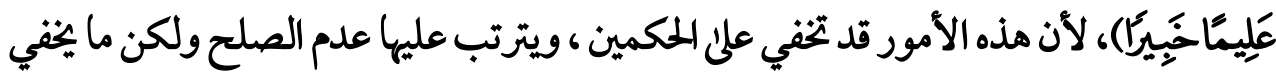

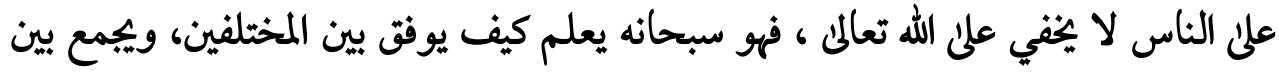

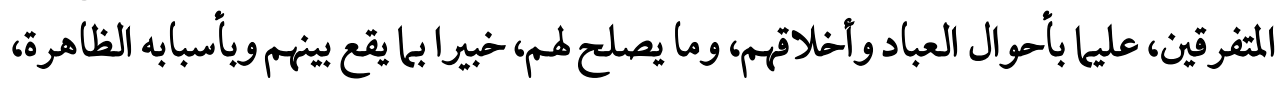

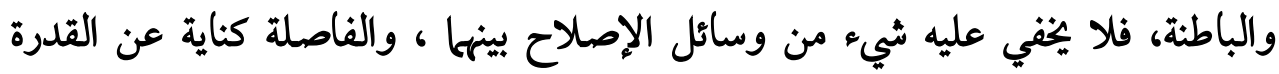

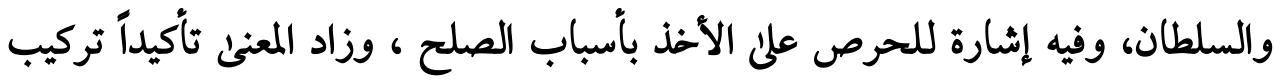

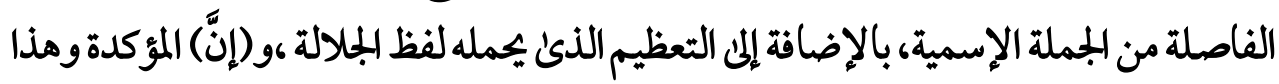

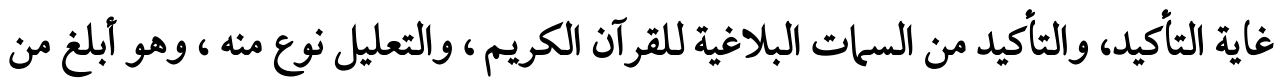

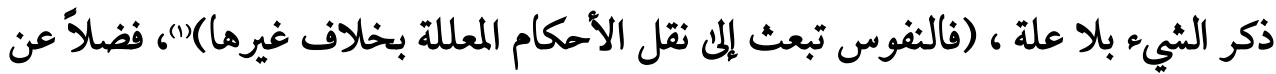

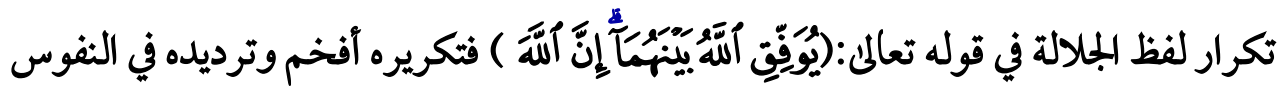

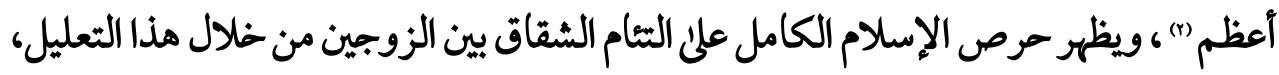

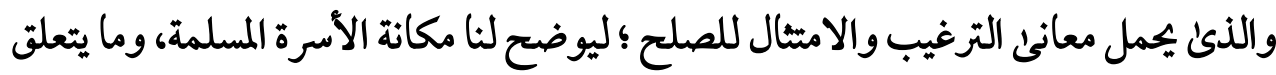

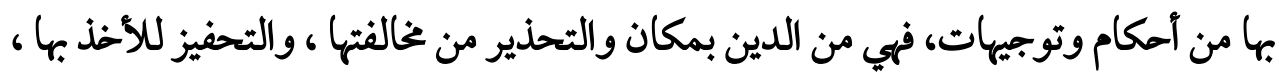

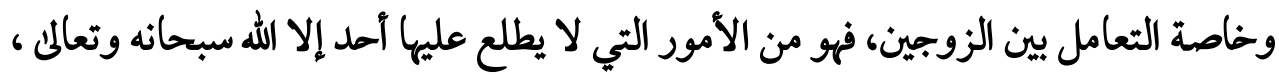

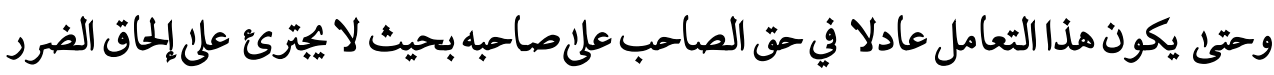

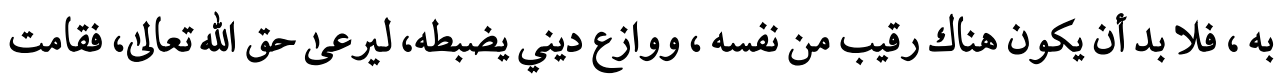
الفاصلة بالتنبيه ، والإشارة لكل هذه المعاني من خلال تركئل تركيبها.

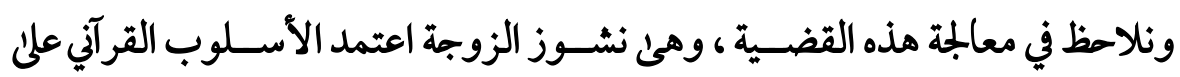

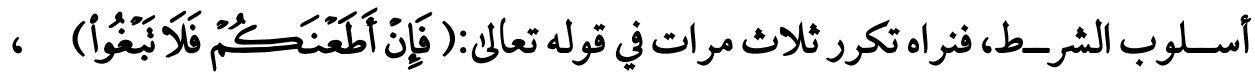

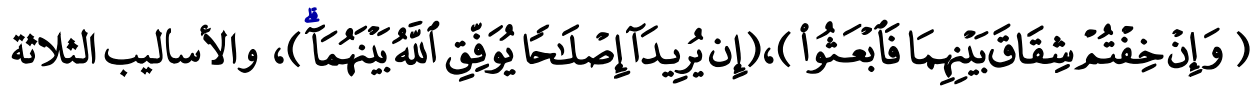

$$
\text { (1) (1) يرابع: البرهان في علوم القرآن (r/ (9) (1). }
$$

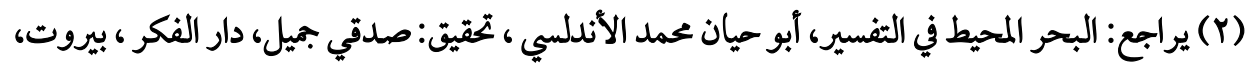

$$
\text { b }
$$




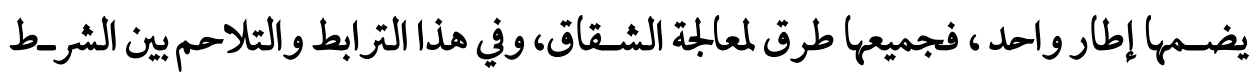

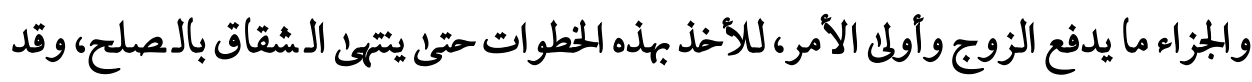

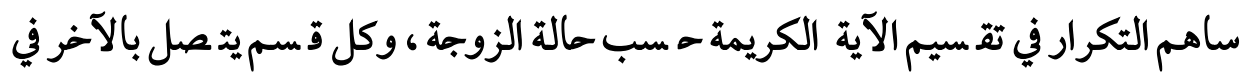

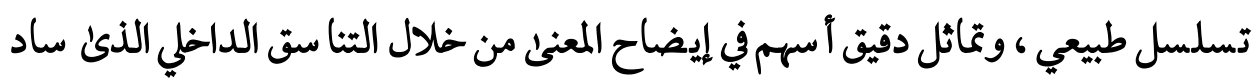

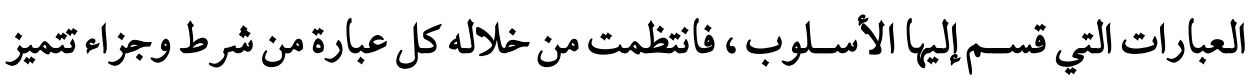

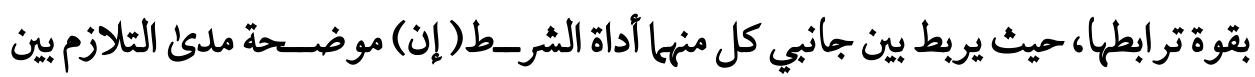

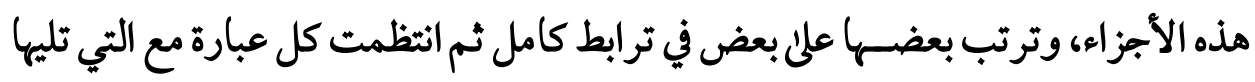

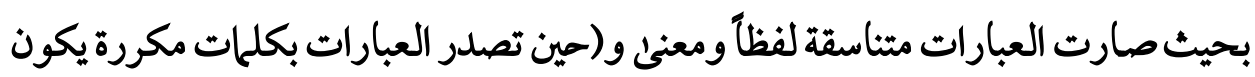
لما من حسن الجرس في الأذن ، وقوة الربط في العقل ، وغيره من الوظائف الثيء الكثير) (").

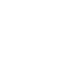

(1) يراجع: من الخصائص البلاغية واللغوية في أسلوب الملديث النبوي الشريف د/ فتحية فرج العقدة ،

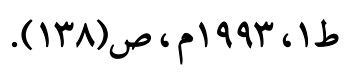




\section{المجدة الثاني \\ البلافة القرآيلة في معالجة نشوز الزوج}

إن الثدبر في كتاب الله عزوجل يظهر لنا وسـطية الشر-يعة الإسـلامية ، ومنهجها العادل في معالجة قضية الشثقاق بين الزوجين ظهوراً جلياً، ونشوء الكراهة ، و سوء المعاشرة من الأمور

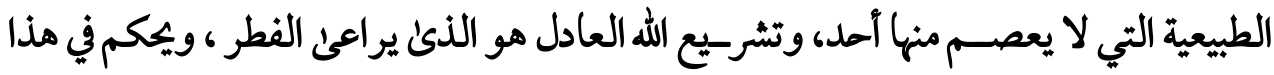

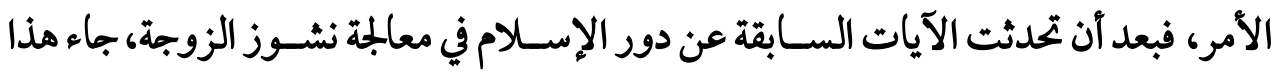
المبحث لنعرض فيه دور الإسـلام في معالجة نشـــوز الزوج ، فمع أن الإسـلام أعطى للرجل

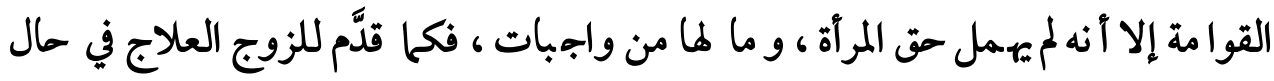

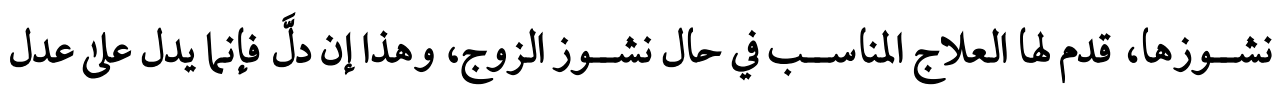

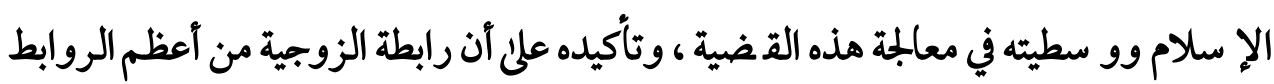
البشرية، وأولاها بالحفظ ، ومن أغلظ المواثيق وأجدرها بالوفاء.

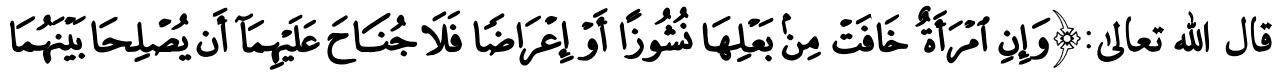

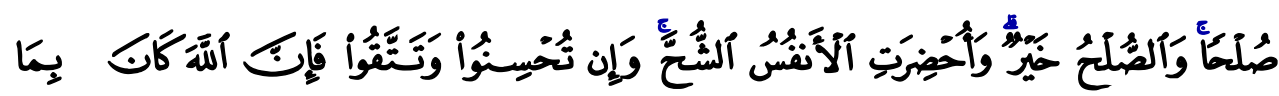

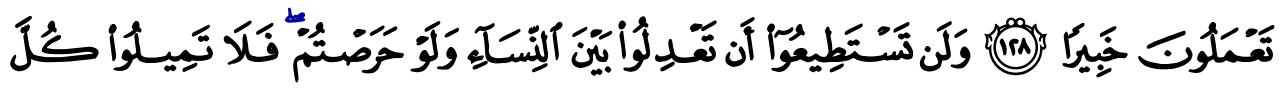

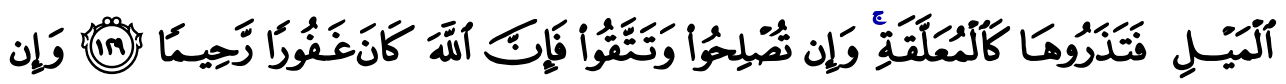

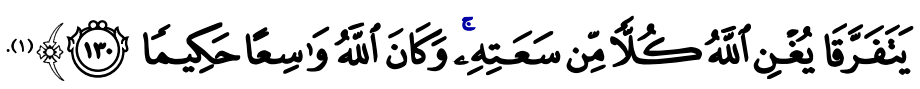

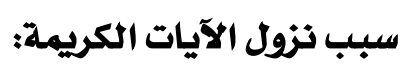

ورد في سبب نزول هذه الآيات الكريمة ثلاثة آقوال:

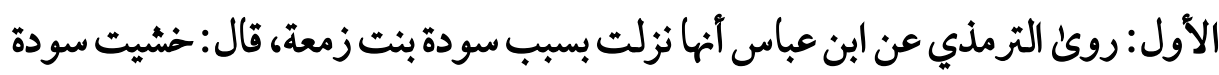

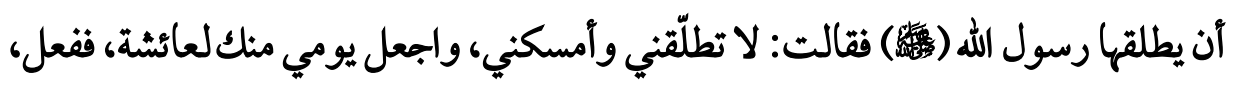

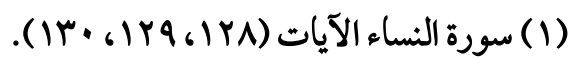




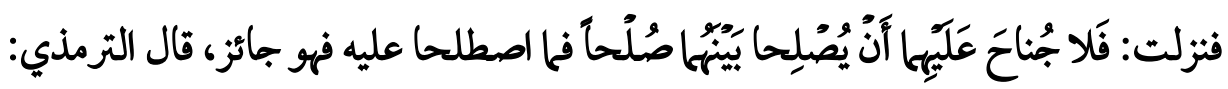
هذا حديث حسن غريب. وروئ أبو داود والماكم عن عائشة مثل ذلك. الثاني: وروئ ابن عيينة وسعيد بن منصور عن الزهري عن سعيد بن المسيب أن رافع بن وردئ

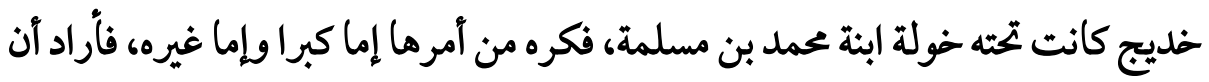

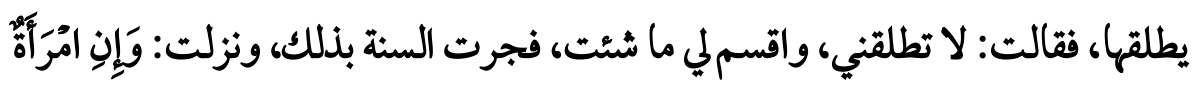

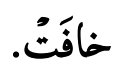

الثالث: أن رجلاً كانت له امرآة كبيرة، وله منها أولاد، فأراد طلاقها، فقالت: لا تفعل، واقسم لي في كل شهر إِن شئت أو أكثر فقال: لئن كان هذا يصلحُ، فهو أحبُ إليّي، فأتىلى رسول

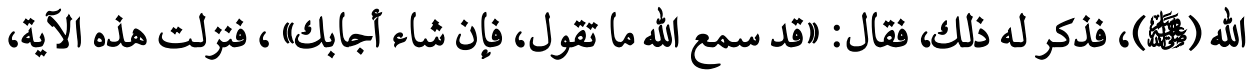
والتي بعدها، رواه سالم الأفطس عن سعيد بن جبير").

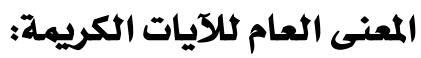

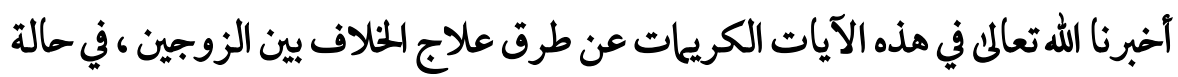
ما إذا كان النشوز من الزوج، وذكر أحوالاً ثلاثة: حال نفور الزوج من المرآة، وحال اتفاقه

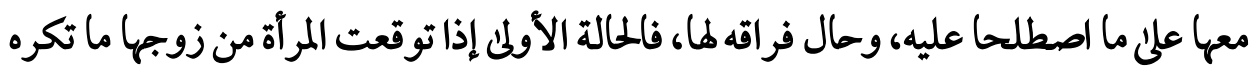
ترفعا وتكبرا عليها، بترك مضاجعتها والتقصير في نفقتها لبغضها وحبه لغيرها، فلاجناح عليها

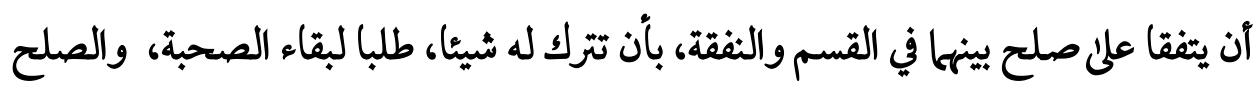

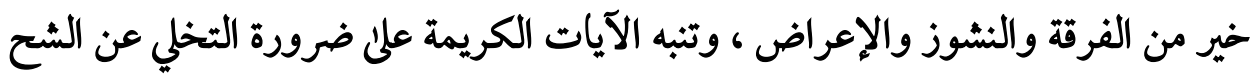
الذئ يجول دون المصالحة ، وتدعوا الآيات الكريمة إلى إحسان العشرة بين الزوجين، وتقوين

(1) يرابع: زاد المسير في علم التفسير لجمال الدين الجوزي المحقق: عبد الرزاق المهدي ، الناشر: دار الكتاب

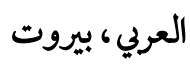

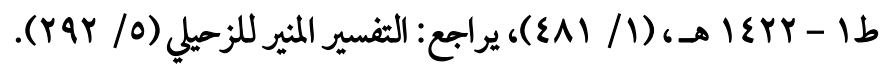


الله تعالى بترك النشوز ، ثم تتدرج الآيات الكريمة، لتبين لنا الحالة الثانية، وهو اتفاقه معها

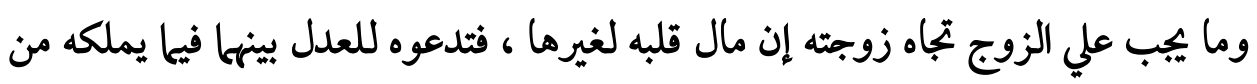

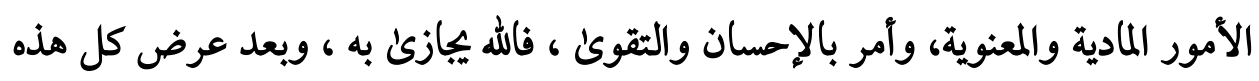
المعالجات والطرق التي عرضها القرآن الكريم رغبة في تحقيق الصلح بين الزوجين، تختم

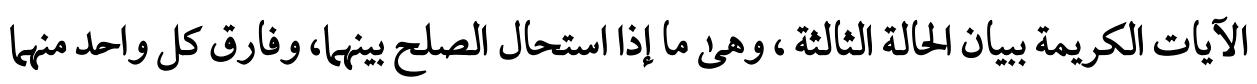
صاحبه ، فسوف يغنى الله كلا منها ، ويرزقه زوجا خيرا من زوجه وعيشا أهنأ من عيشه، فالله واسعا لخلقه في الفضل حكيا فيا دبره لهم. التحليل البلاغي للآيات الكريمة: جاءت هذه الآيات الكريمة معطوفة علئ ما قبلها، حيث تتحدث الآيات السـابقة عن أحكام

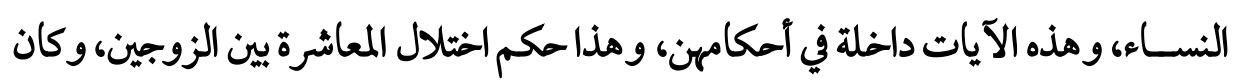

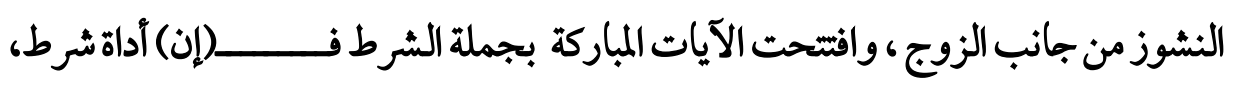

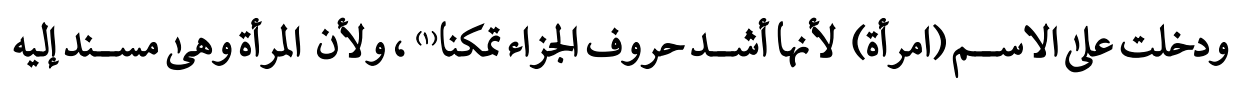

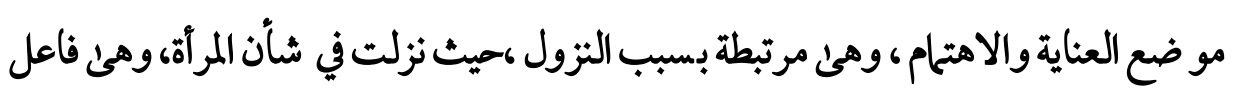

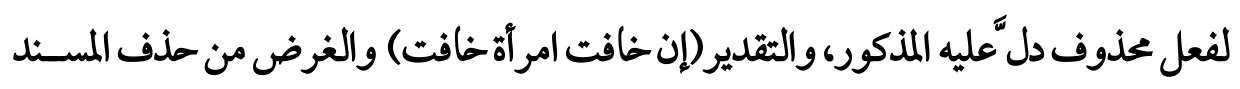
هو تقوية اللحمم، وللاهتحام بالفاعل ، لتسـليط الضـوء عليه، وقد حذف الفاعل من جملة (خافت) الثانية أيضـا لهذا الغرض ، فكان الحذف بمثابة التكرير للجملة، والتأكيد على معناها بجملتين متتاليتين، والحذف في القرآن الكريم من دلاثل إعجازه وإييازه، قال الثعالبي (من

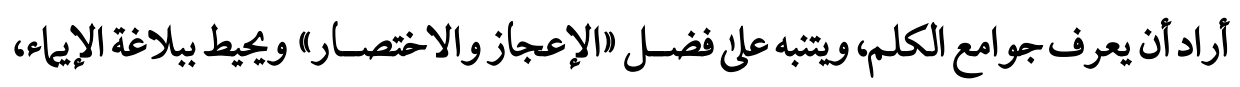

(1) يرابع: معانئ القرآن لأبئ المسن البصري، المعروف بالأففش تحقيق: الدكتورة هدئ محمود قراعة،

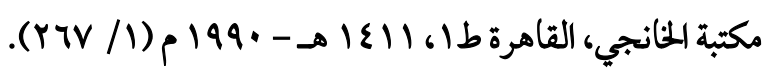


ويفطن لكفاية الإيجاز: فليتدبر القرآن)(1) ، و(خافت) فعل ماضي، وقدعدل عن المضارع رغم

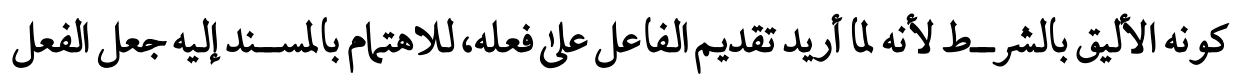

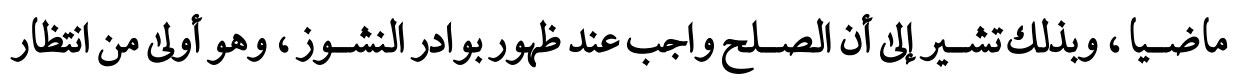
وقوعه ، ليمكن تدارك اللططب قبل وقوعه(()، والخوف هنا بمعنئ ( توقع ما يكره بوقوع أسبابه،

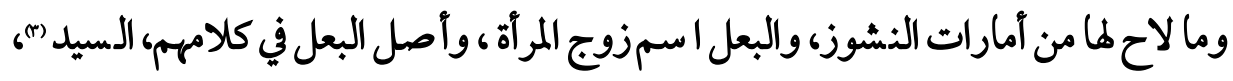
ولما كان المقام مقام تذكير بحاللزوج من سيادة، عبر القرآن بلفظ البعل، ولميعبر بالزوج ؛ لأن الزوج يصـدق على الزوجة أيضـآ، وقد جاء التعبير بكلمة "امر أة" دون زوجة ؛ لأن القرآن

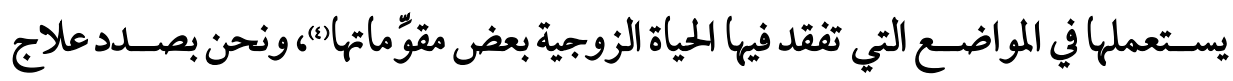

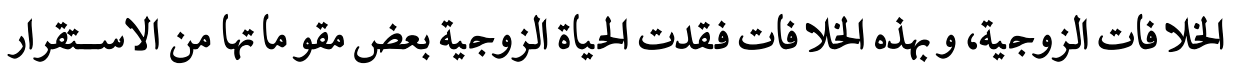
والمودة، فكانت اللفظة دقيقة في مكانها ، وا ستقصت الآية الكريمة كل أنواع البعد التي يمكن

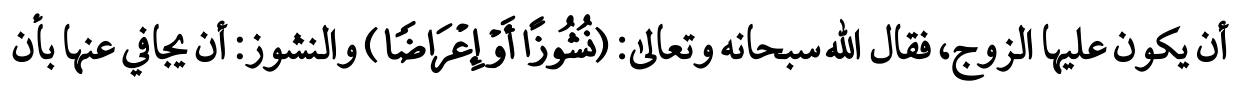
يمنعها نفسـه ونفقته، والمودة التي بينها، وأن يؤذيها بسـبـ أو ضرب، والإعراض: آن يقل

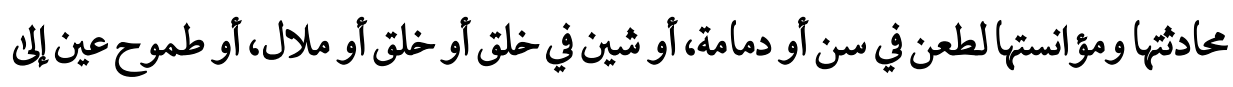

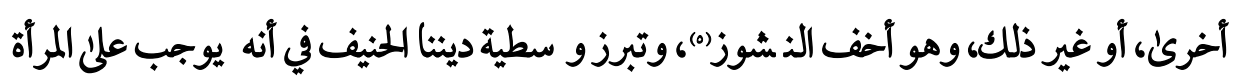

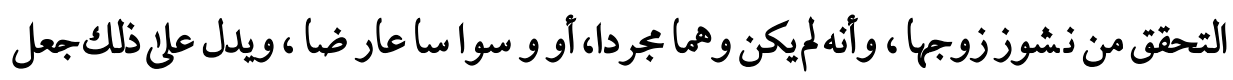

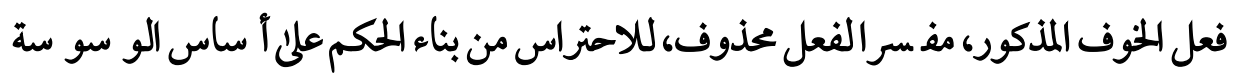

(1) يراجع: الإعجازوالإيياز لعبد الملك بن حممد أبو منصور الثعالبي ، مكتبة القرآن، القاهرةص: (9).

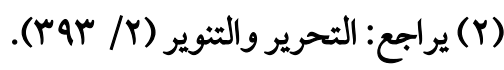

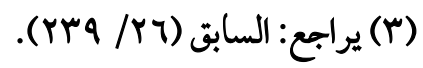

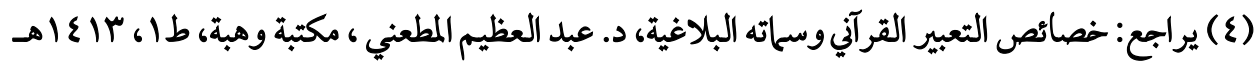

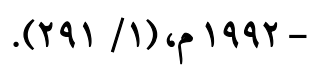

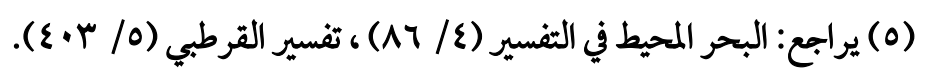


التي تكثر عند النسـاء، وهو من إيجاز القرآن البديع، فيقول صـاحب المنار:(وذلك أن المرأة إذا رأت زوجها مشغولا بأكبر العظائم المالية أو السياسية، أو حل أعوص المسائل العلمية، أو بغير

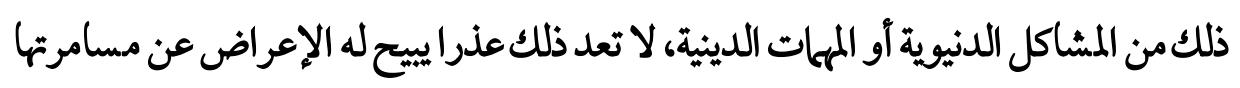

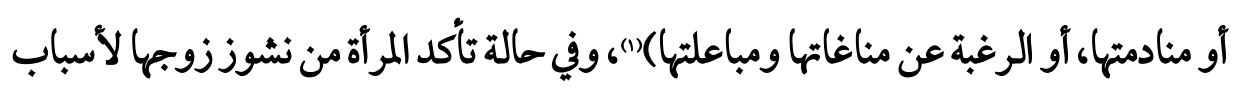

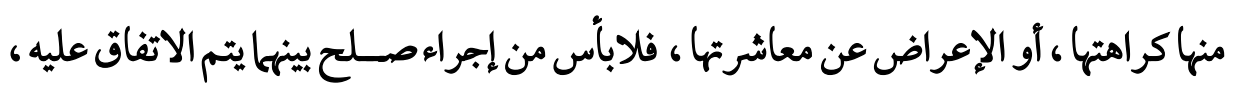

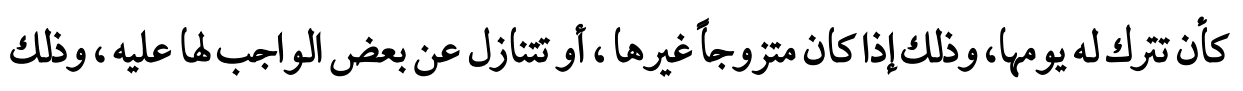

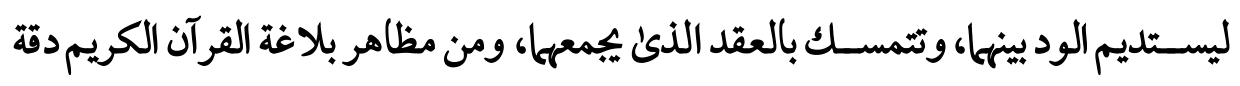

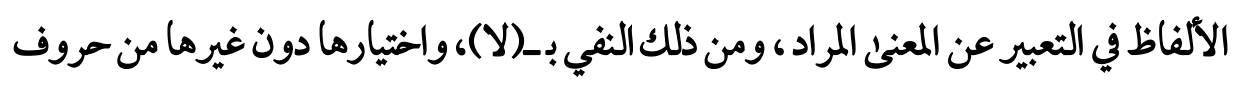

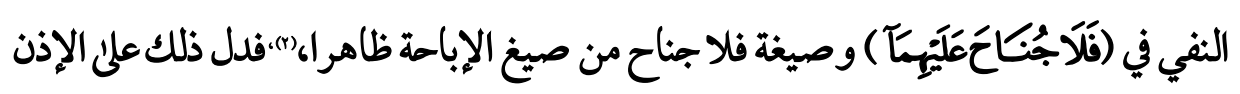

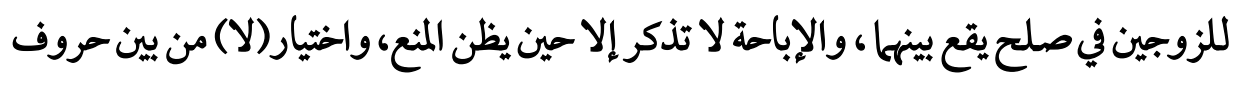

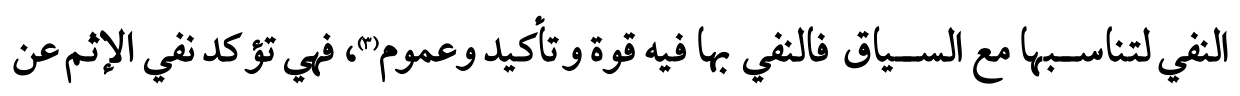
الزوجين من عقد هذا الاتفاق، وتنازل الزوجة عن بعض حقوقها مقابل إبقاء الرجل عليها ،

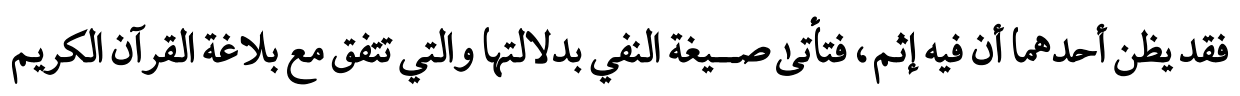

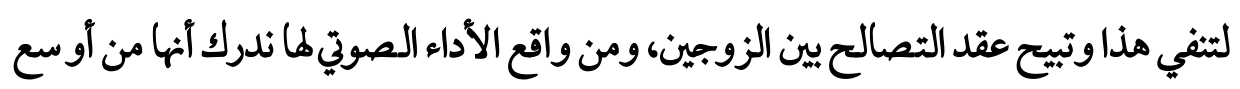

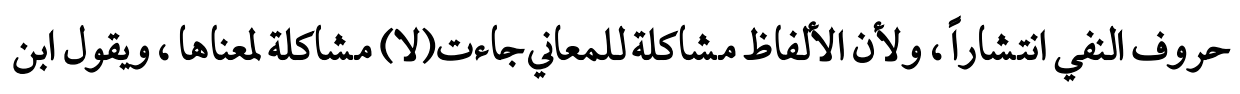

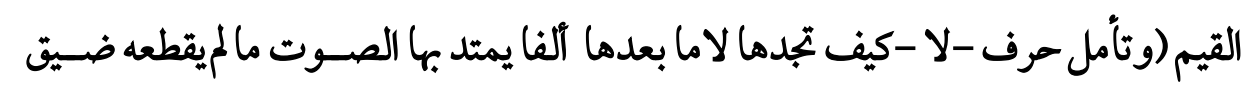

$$
\begin{aligned}
& \text { (1) يراجع: تفسير المنار (0/ بآب). }
\end{aligned}
$$

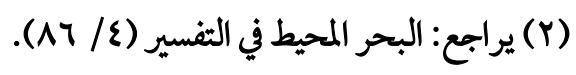

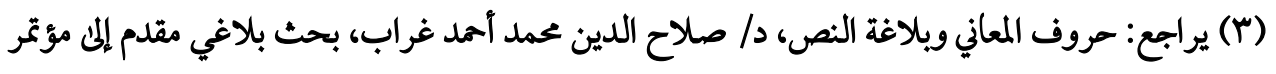

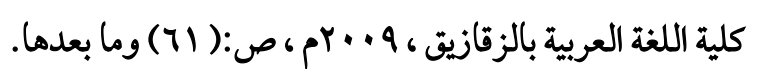


النفس فآذن امتداد لفظها بامتداد معنا ها)(")، والجناح هو : الإثم أو الحرج")، ودخول النفي المباشر عليه في الجملة، وهو المسند إليه دلَّ على نفي جنس الإثم قليله و كثيره، وهذا فيه إ شارة إلى الترغيب في التدخل السرـيع، لفض النزاع والقضــاء على الثــقاق بين الزوجين ، ولفظ

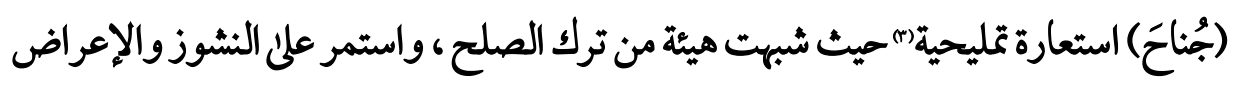

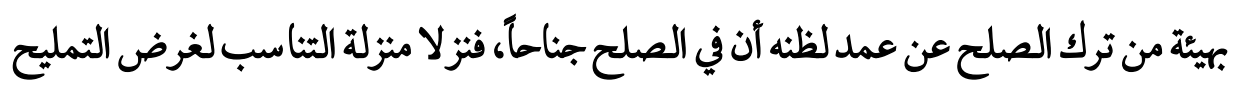
علني سبيل الاستعارة التمثيلية والغرض منها لفت الانتباهلخيرية الصلح للمسارعة إليه وتمليحها بترك الإثمفيه، ومن بلاغة القرآن الكريم أنه رتب رفع الجناح علئ بجرد اللخوف من النشوز، لا لا حدوث النشوز بالفعل ، والضمير في(عليها) يعود إلى الزوجين .

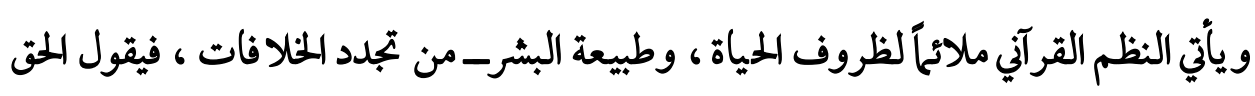

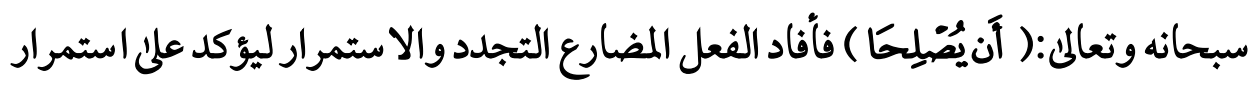

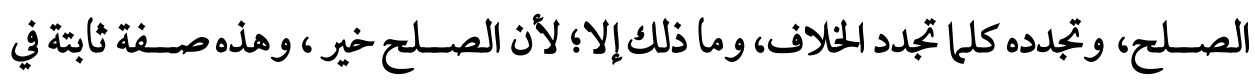
المجتمع الإسلامي تدلل علإ و سطيته وعدله ، ونبذه للجفاء والمشاحنات ، ودعوته للصلح في كل زمان ومكان، والضمير في (بينها) يعود إلى الزوجين، ويستخدم القرآن الكريم التوكيد

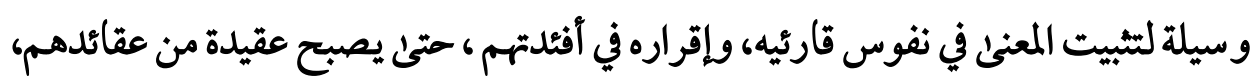

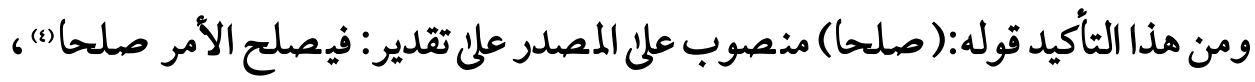

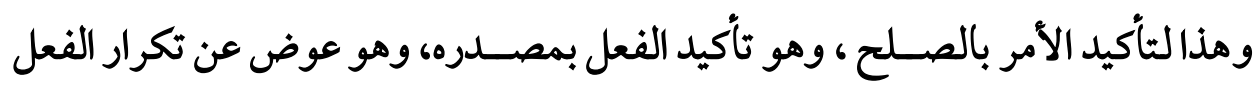

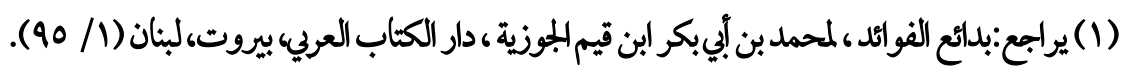

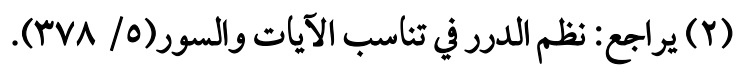

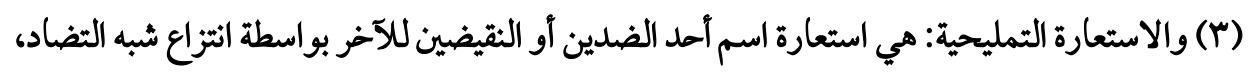
وإلماقه بشبه التناسب بطريق التمليح ، ثم ادعاء أحدها من جنس الآخر والإفراد بالذكر ونصب القرينة.

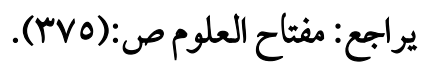

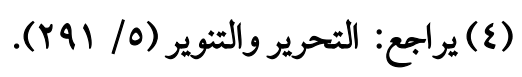


مرتين ورفع توهم المجاز في الفعل فقد يطلق الكلام علن الإيحاء والمجاز، وينصر-ف الذهن

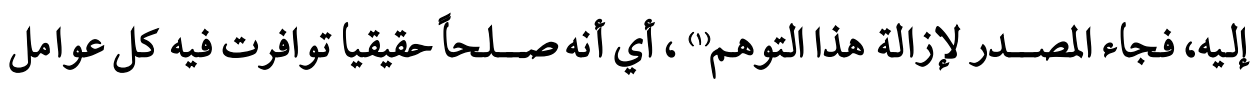

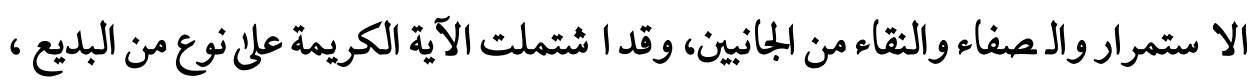

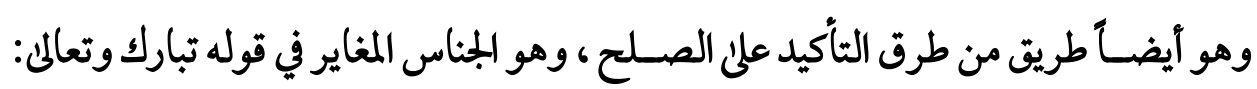

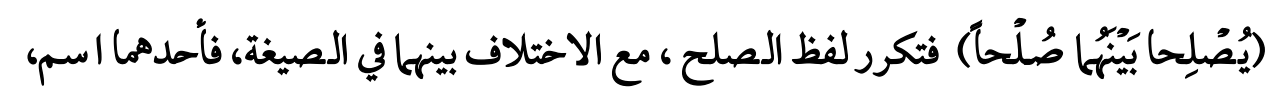

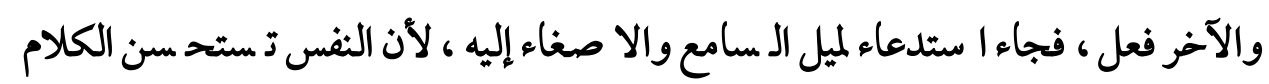

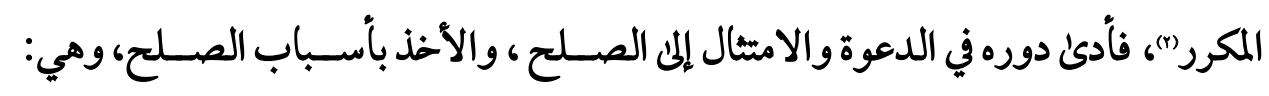

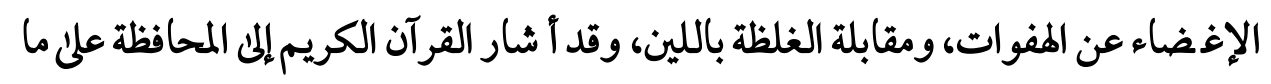

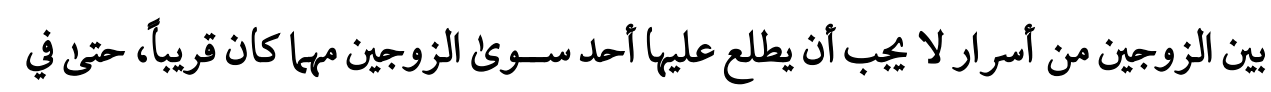

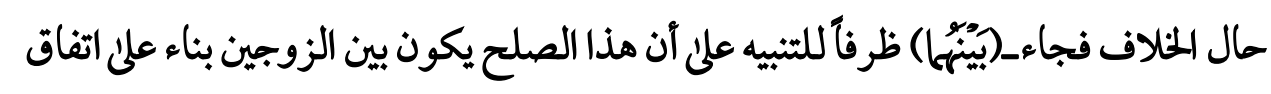
بينها، أو حال من صلحا أي كائنا بينها|(r) .

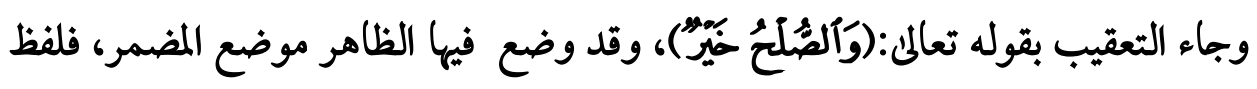
الصلح قد ذكر سابقاً، وكان السياق يقتضئ (وهو خير) ولكن عدل عن الضمير إلى التعبير بالظاهر، للترغيب في الصلح بين الزوجين، كما آن ذكره قوى إسناد الخيرية له، وأنه أفضل

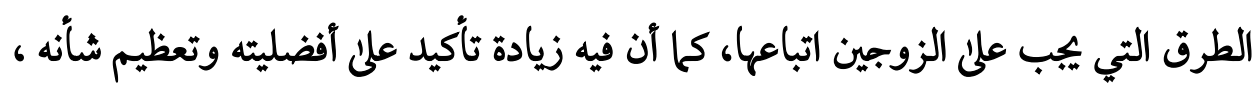

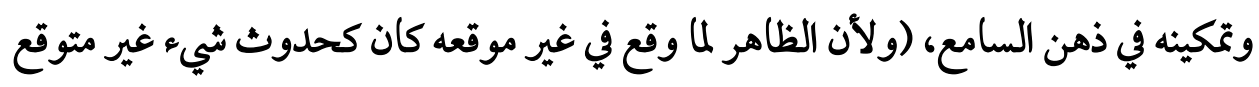

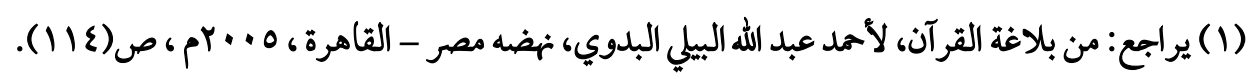

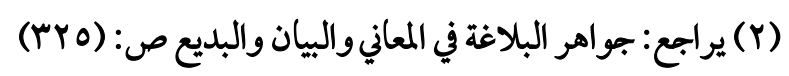

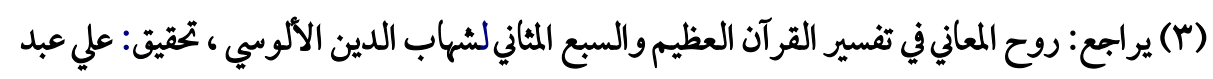

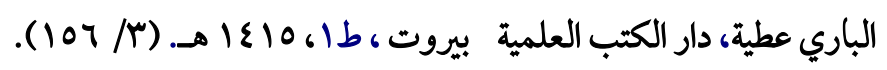


فأثر في النفس تأثيراً بليغآ)، ، وقد اشتملت مذه الجملة أيضاً على الإطناب المتمثل في التذييل،

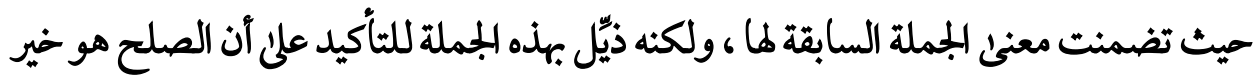
للناس، وبذلك (قد دلت الآية على شدة الترغيب في هذا الصلح بمؤكدات ثلاثة: وهي المصدر المؤكد في قوله: صلحا، والإظهار في مقام الإضمار في قوله: والصلح خير، والإخبار

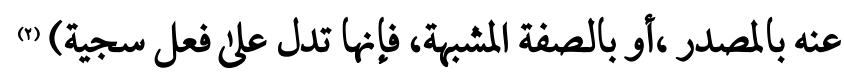

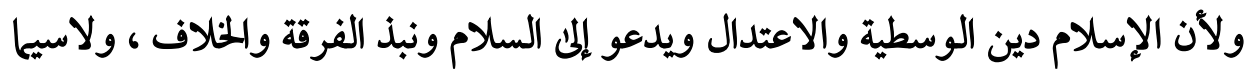

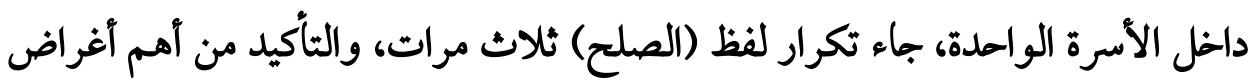

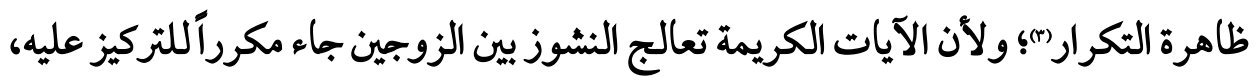

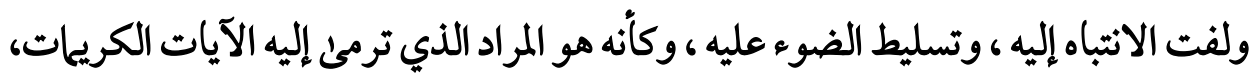

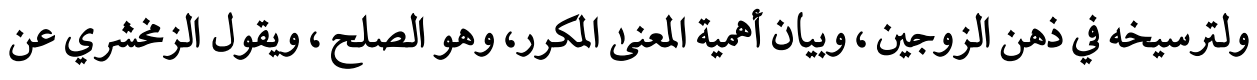

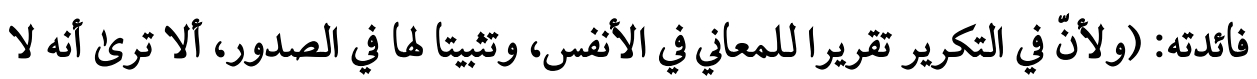
طريق إلمن تحفظ العلوم إلا ترديد ما يراد تحفظه منها، وكلما زاد ترديده كان أمكن له في القلب،

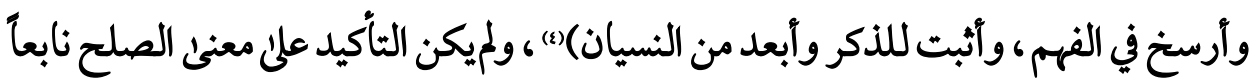

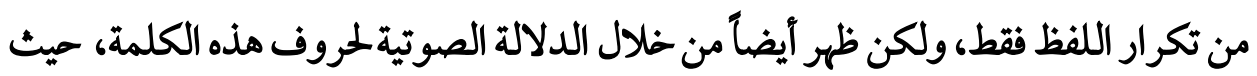
جاءت الكلمة تتألف من حروف تدل على معناها ، فجاءت (الصاد) وهنى من الحروف

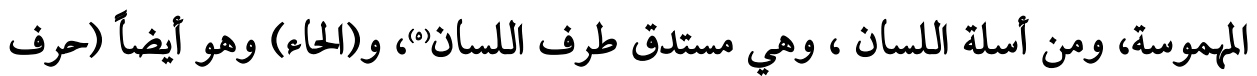

$$
\begin{aligned}
& \text { (1) يراجع: حاشية الدسوقي على شرح السعد ضمن (شروح التلخيص) (I / ( ) ) ). }
\end{aligned}
$$

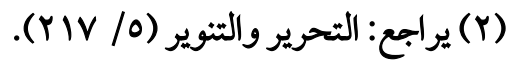

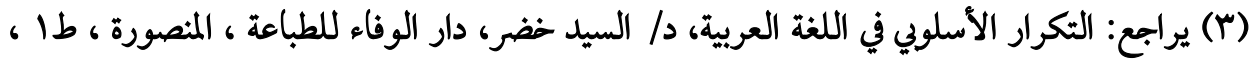

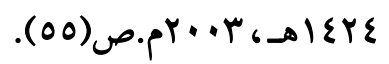

(ع) يراجع: الكثاف عن حقائق غوامض التزيل (r/ ع ع (Y)).

$$
\text { (0) يراجع: لسان العرب (r/ (Y). }
$$


مهموس رخو رقيق ، أشبه ما يكون بالحفيف ، ويوحئ عند نطقه بملمس الحرير)(')، فلا نجد

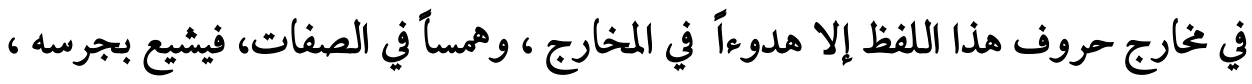

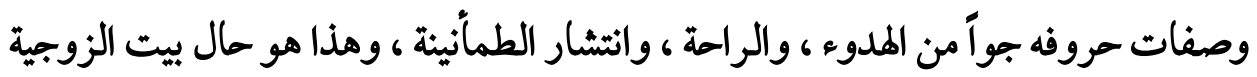
عندما يتم الصلح بين الزوجين.

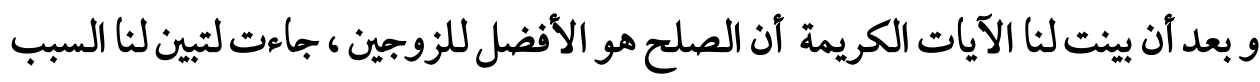

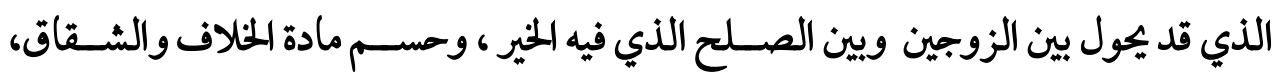

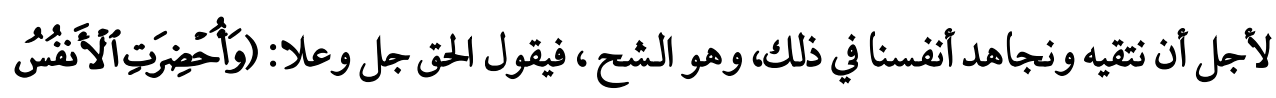

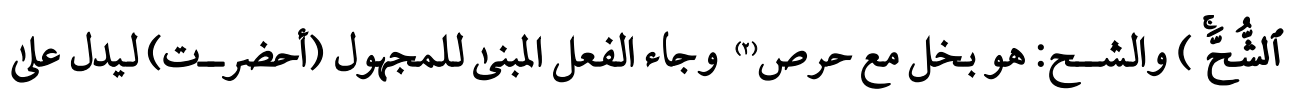
عموم وشــمول تلك الصـفة، وتمكنها من نفوس البشر-، وليبين أن الثــح مركوز في الجبلة

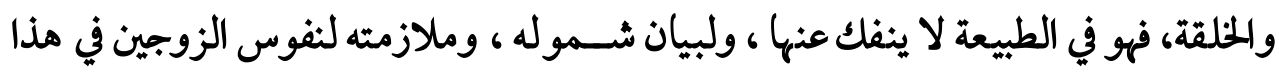
الوقت، بسبب الملاف ، ويقول صاحب التحرير (ولكونه من أفعال الجبلة بني فعله للمجهول

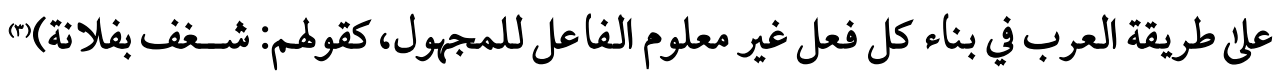

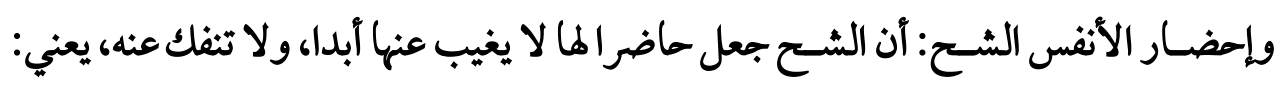

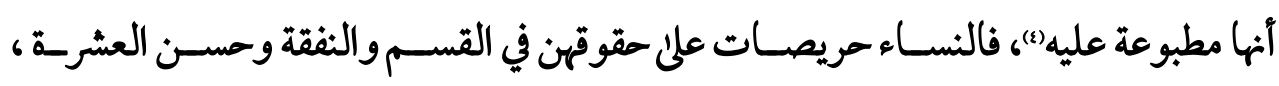

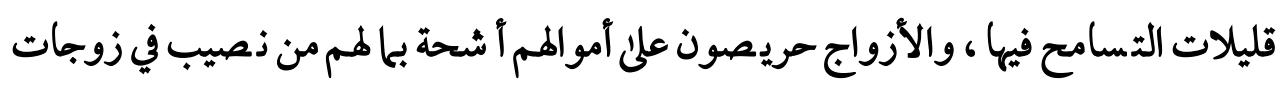

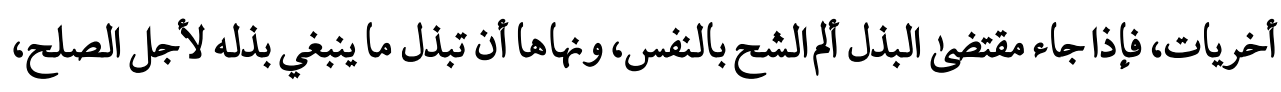

(1) يراجع: خصائص الحروف العربية ومعانيها ، حسن عباس ، اتحاد الكتاب العرب، 1991 (م) ص: (11)،

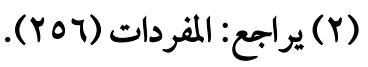

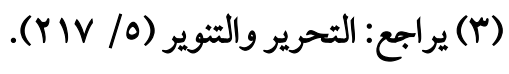

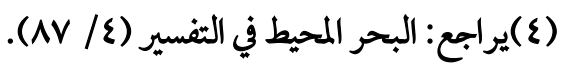


وإقامة المصلحة ، وهلى جملة معتر ضة ، لتمهيد العذر في الماكسة والمشاقة")، وهئ معطوفة على

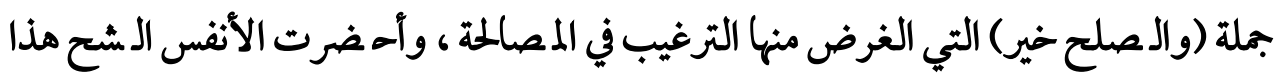

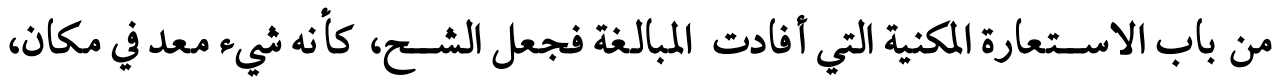

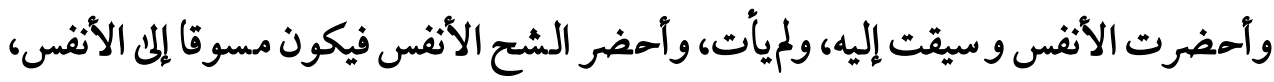

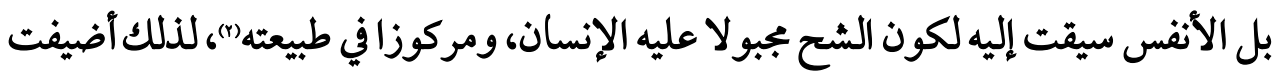
إلى النفس (ليس المراد أن محضر أهضر الأنفس شحها، ولكن الشحق، لما كان غير مفارق لها،

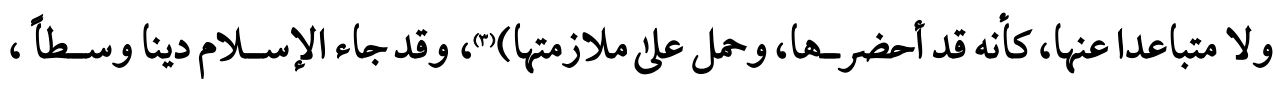

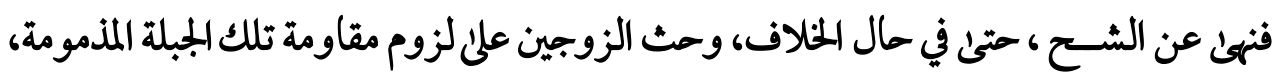

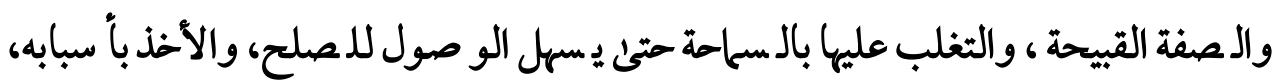

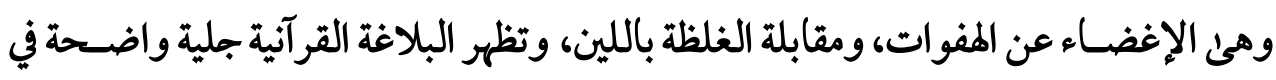
اختيار المفردات التي تعبر عن المعنى بدقة فائقة، حيث جاءت الآية الكريمة بلفظ (الشـح)

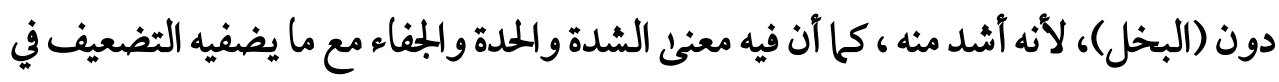
الملمة من معنى المبالغة ، وهو يشمل الشح بالمال، والمثاعر. ويعد التنفير من هذه الصفة الذميمة، والتحذير من الأسباب المانعة من الصلح ذيّلّت الآية

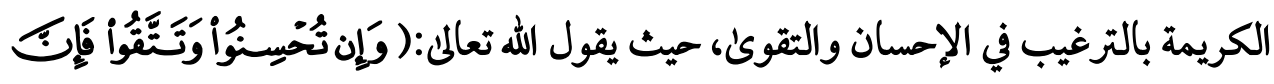

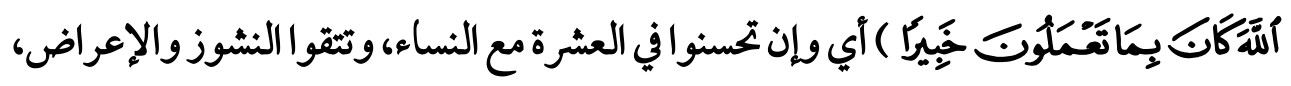

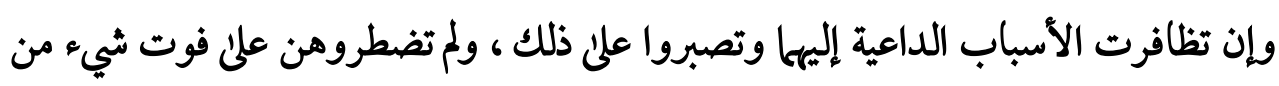

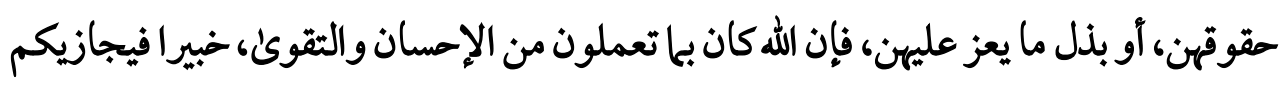

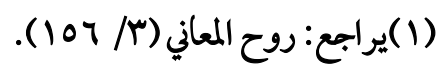

$$
\begin{aligned}
& \text { (Y) يراجع: البحر المحيط في التفسير (乏) / (Y). }
\end{aligned}
$$

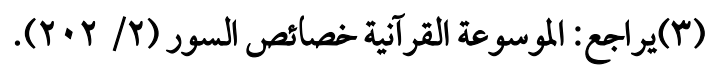




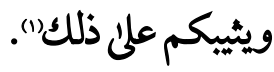

وتظهر بلاغة القرآن الكريم ودقته في اختيار اللفظة القرآنية حيث عبر عن رعاية حقوق النساء بالإحسان، فالإحسان قد يكون واجبا وغير واجب()، وهذا يقتضئ دعوة الإسلام للإحسان من الزوج على أية حال سواء كان هناك سبب لمذا النشوز، كتقصير من المرآة في حقوقه ، فيكون هنا غير واجب، أو من غير سبب ، فيكون الإحسان واجباً عليه، وهذا المعنى لا يأتي مع لفظة أخرى غير هذه اللفظة، وجعل النشوز والإعراض عن الزوجات مما يتقىل منه ، فالاتقاء فيه معنى الاحتراس(r) من ظلمهن، واختيار هذه الألفاظ دون غيرها غاية في البلاغة ، فكلا اللفظين أدى دوره في الدعوة إلى حسن العشرة والتقارب بين الزوجين، فيقول ابن الآثير: (ندب تعاله إلى الإحسان في العشرة على النساء وإن كرهن مراعاة لحق الصحبة، وأمر بالتقوى في حالمن، لأن الزوج قد تحمله الكراهة للزوجة على أذيتها وخصومتها، لا سيا وقد ظهرت منه أمارات الكراهة

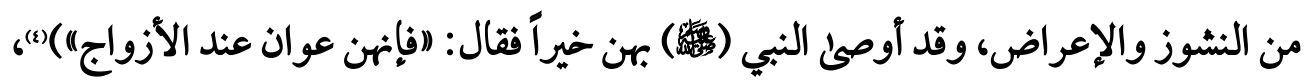
كحا آن التعبير عن الإحسان، والاتقاء بالفعل المضارع يدل على الأمر بتجددهما ، واستمرارهما لما له له من دور في بقاء العشرة والمحافظة عليها ، بالإضافة إلى الالتفات الذئ اشتملت عليه الآية الكريمة، حيث جاءت في الحديث عن هذه الحالة من نشوز الزوج بأسلوب الغيبة ثم انتقلت إلى

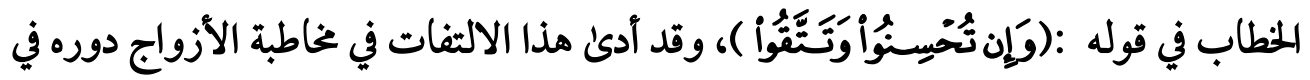
الاستحالة والترغيب في حسن المعاملة من خلال التكريم والتعظيم بالخطاب لمن يقوم بهذا الإحسان والاتقاء، ومن بلاغة الالتفات ( أنه أبلغ في تجديد نشاط السامع ، وأكثر إيقاظًاً لمشاعره

$$
\begin{aligned}
& \text { (1) يراجع: روح المعاني(r/ (1) ). } \\
& \text { (Y) يراجع: الفروق اللغويةص: (Y) (19). } \\
& \text { (Y) } \\
& \text { (ع) يراجع: البحر المحيط في الثفسير (ع / (1). }
\end{aligned}
$$


فيقع في نفسه موقعاً حسناً ، ويحقق فوائده المرجوة)(1).

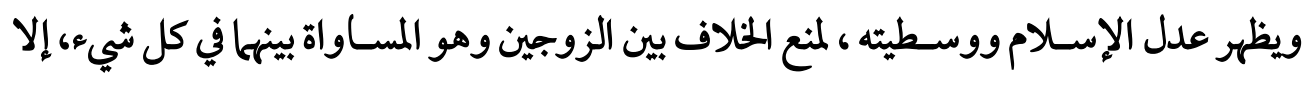

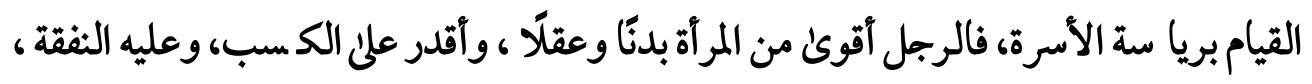

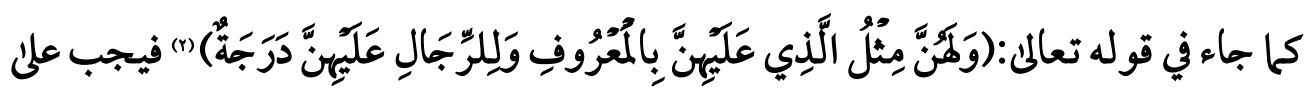
الزوج حسن المعاشرة، والعدل قدر المستطاع.

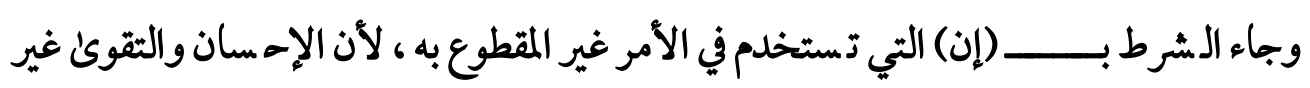
مقطوع به في هذا الوقت، أي وإن تحسنوا بالإقامة عليها مع كراهتكم لصحبتها، وتتقو اظلمها،

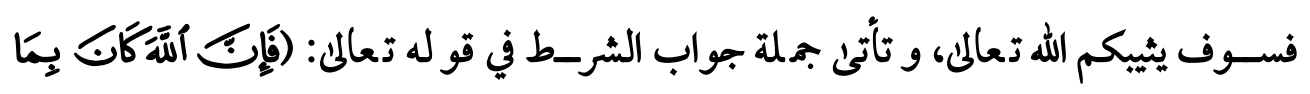

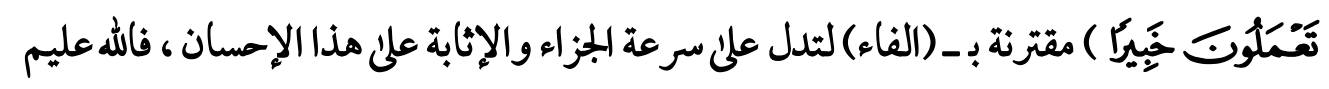
لا يخفي عليه شيء بما تعملون من الإمسان وغيره ، و سوف يجازيكم عليه الجزاء الأوفى (وختم آخر هذه (الآية) بصـفة الحبير وهو علم ما يلطف إدراكه ويدق، لأنه قد يكون بين الزوجين من من الإهن

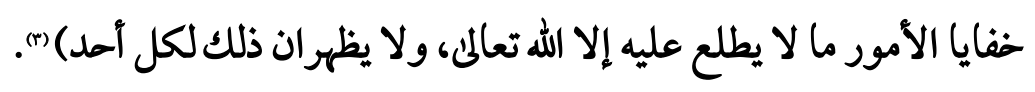

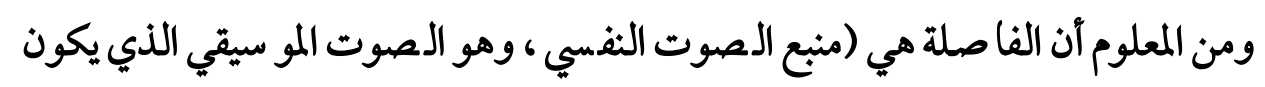
من تأليف النغم بالحروف، ومخارجها وحركاتها ، ومواقع ذلك من تركيب الكلام ونظمه علني طريقة متساوقة، وعلى نضد متساو، بحيث تكون الكلمة ، كأنها خطوة للمعنى في سبيله إلى مالى

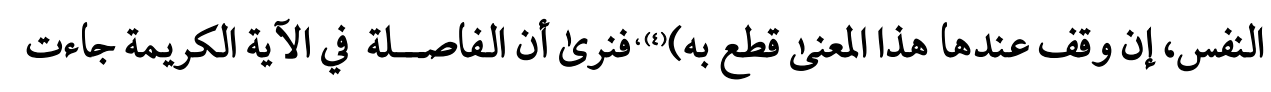

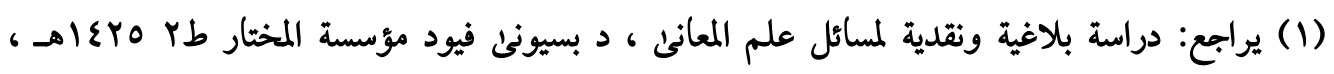

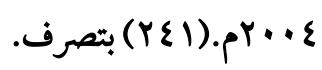

$$
\begin{aligned}
& \text { (Y) سورة البقرة: الآية (YY) (Y) (Y) }
\end{aligned}
$$

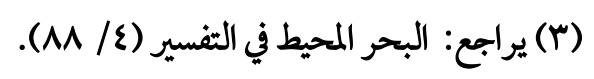

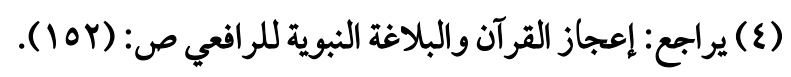


جامعة بين محاســن الصــياغة ، وبلاغة المعنى بإحكام ، فجاءت بليغة في موضـعها موافقة للنسق، حيث أقام الله سبحانه وتعالم كونه عالماً بأعالمهم مقام إثابته إياهم عليها الذي هو في الحقيقة جواب الشرط إقامة للسبب مقام المسبب"). ثم تأتثى الآيتان الكريمتان، لتيينا لنا سببآ آخر من أسباب الشقاق ، وهو اتجاه الزوج لزوجة أخرىئما ينشى عنه الكراهية في قلبه ، ويبعه على النشوز والإعراض، فيظلم ولا يعدل، وحرصاً من الإسلام علئ معللجة الشقاق، ومحو أسبابه بين الزوجين ، يدعو الرجال في هذه الآية الكريمة إلى العلل بين الزوجات ، وقد اشتملت الآيتان على عدة معانىل ، وجاءت الألفاظ القرآية غاية في الدقة للتعبير عن هذه المعاني، فقررت الآيتان في البداية طبيعة الضعف البشرئ في العدل بين الزوجات ،حيث يقول الله

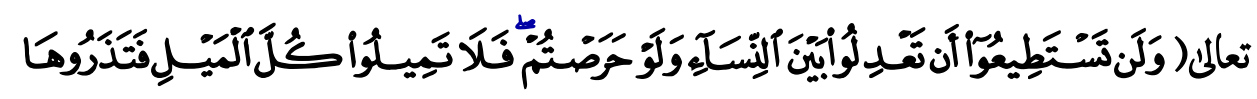

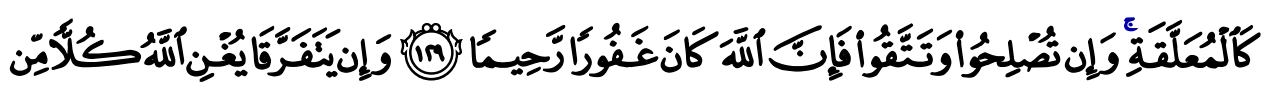

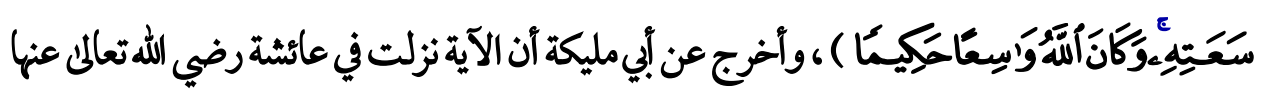

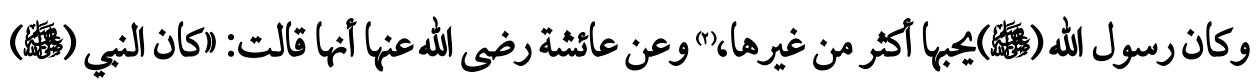
يقسم يين نسائه فيعدل ثم يقول: اللهم هذا قسمي فيا أملك فلا تلمني فيا تملك ولا أملك)(ه) فجاءت الآية مستهلة بـأداة النفي (لن) للمبالغة في النفي، وهو غختص بالمضارع، ينصبه بنفسه، ويخلص زمنه للمستقبل ، فنفت استطاعة العدل بين الزوجات علنى الدوام سواء في اللحال أو الاستقبال (s)، ولكن توخى الحرص والمقاربة مطلوب، فالله الذئ فطر تلك النفوس البشرية يعلم أنها ذات ميول لا تملكها ، ومنها ميل قلب الزوج إلى إحدى' زوجاته ، فيؤثر واحدة

$$
\begin{aligned}
& \text { (1) يراجع: تفسير البيضاوي (Y/ . (1). }
\end{aligned}
$$

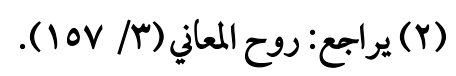

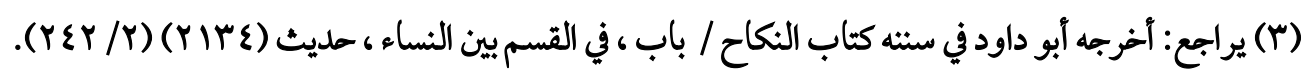

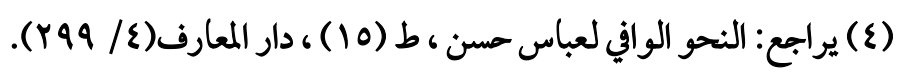


عن الأخرىي، وتفاوت النساء في الحسن وخفة الروح وكرم الحلق أمر يغالب نفس الزوج،

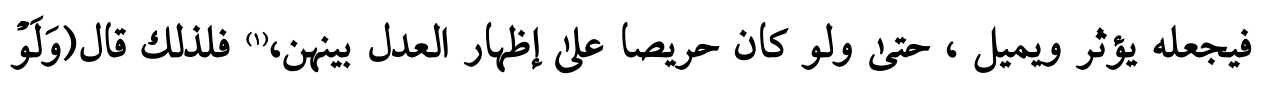

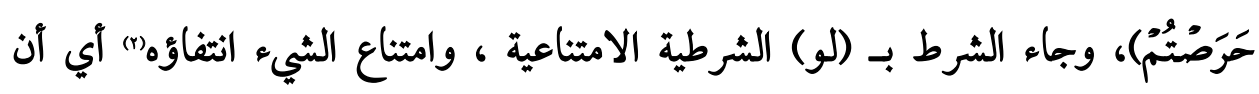
الاستطاعة منفية، فامتنع العدل حتى مع الحرص لعدم الاستطاعة علن ذلك.

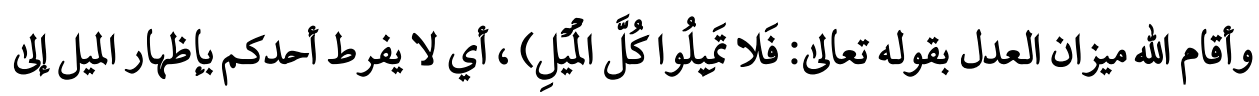

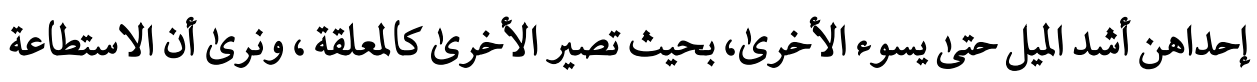
على العدل منفية في صدر الآية حتى مع الحرص ، وجاءت(كل) ودخلت على المعرفة للتأكيد

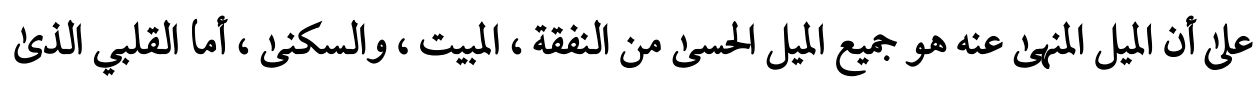

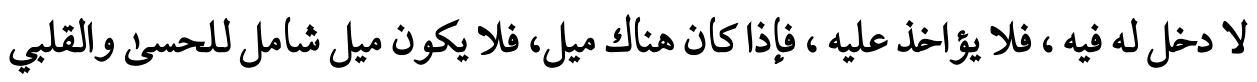

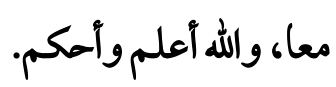
و نرئ القرآن الكريم يقدم للحياة الزوجية ما يضمن السعادة والاستقرار لما، فجاء أسلوب

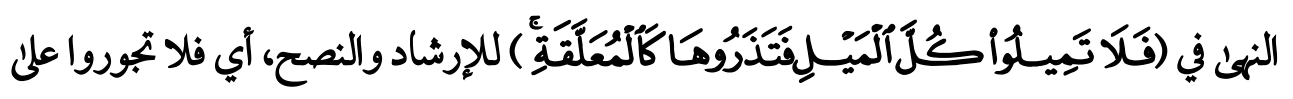

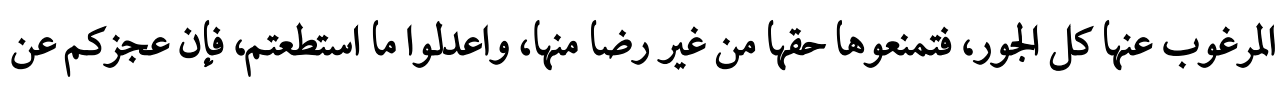

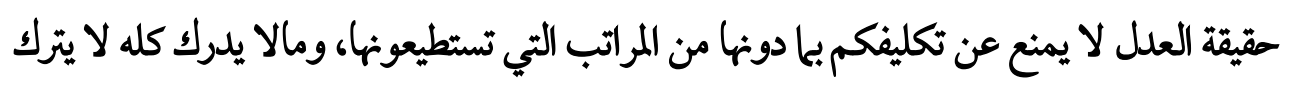

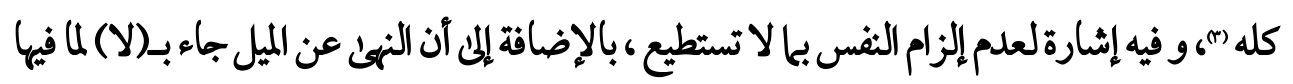
من استطالة في النطق يجاكئ استطالة النهن عنه .

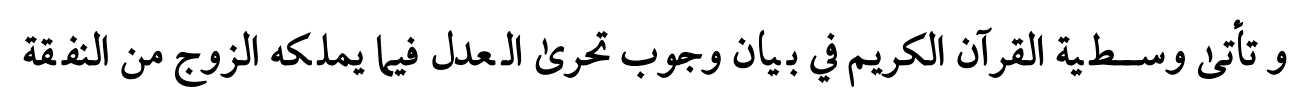

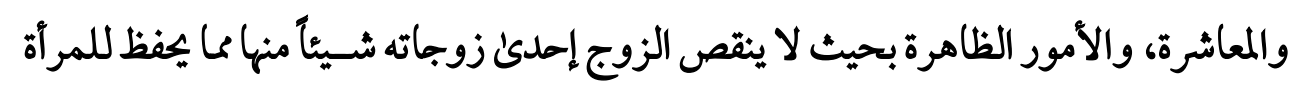

$$
\begin{aligned}
& \text { (1) (1) يراجع: التحرير والتنوير (Y / / / ب بتصرف. }
\end{aligned}
$$

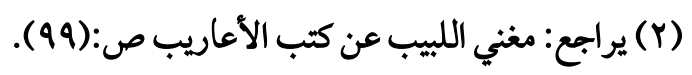

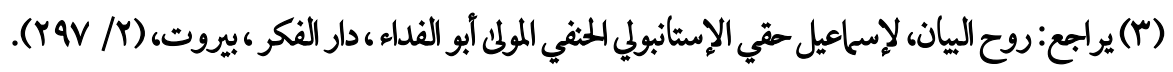


حقها وكرامتها، وفي الوقت ذا ته عدم تكليف الزوج ما لا يطيق ، ولا يقدر عليه من العدل

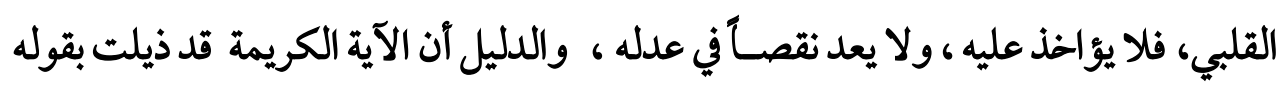

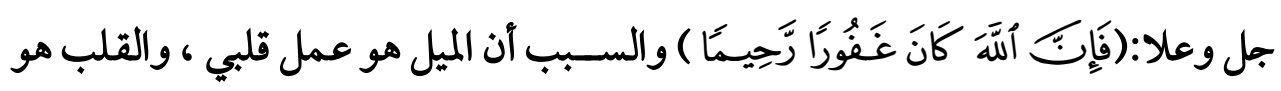
الذئ يحرك الجوارح، ويحمل أيضاً في طياته معنى التوبيخ لمن لميراع حق الله في العدل المتاح بين

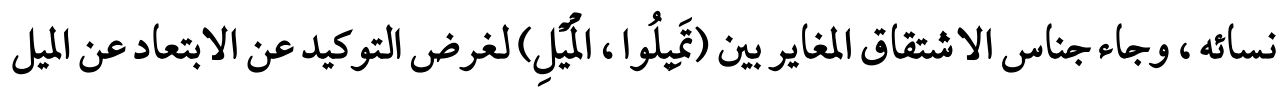

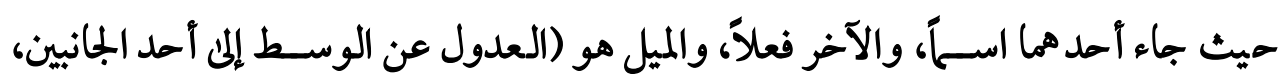
ويستعمل في الجور، وملت عليه: تحاملت عليه)(') ، فلو اقتصرت الآية الكريمة على ذكر الفعل الفعل

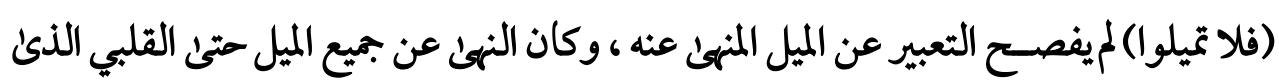

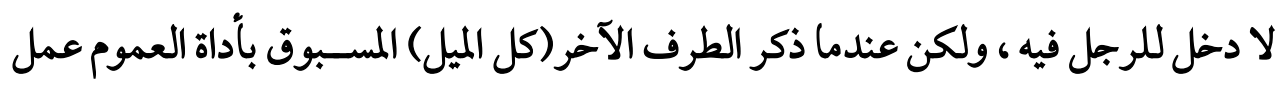
الجناس على ترديد صوتي من خلال تكرار حروف الكلمة لتصور المعنى بصورة مكثفة، وتؤكد علي ضرورة تجنب الميل قدر المستطاع فيها يملكه الزوج ، فجاء المناس في الآية ملمحا أسلوييا

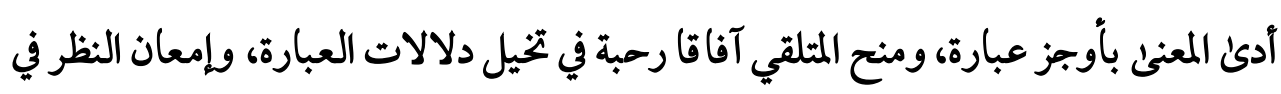

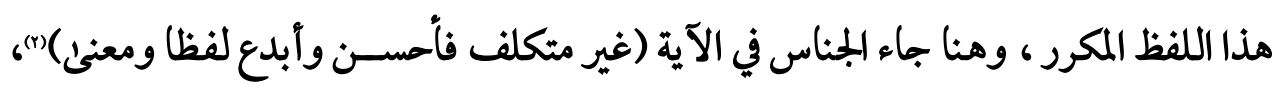

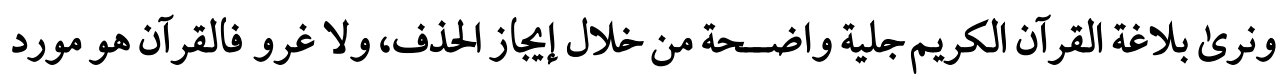

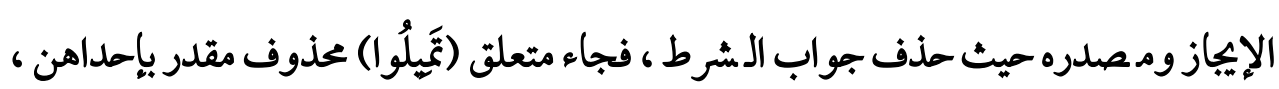

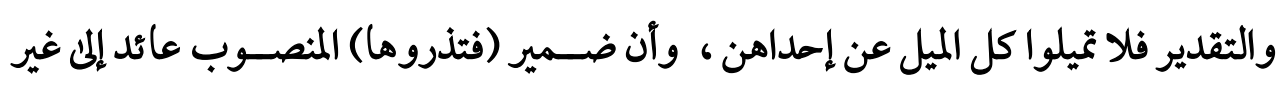

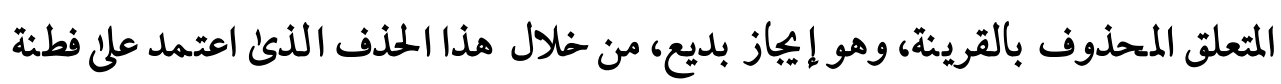

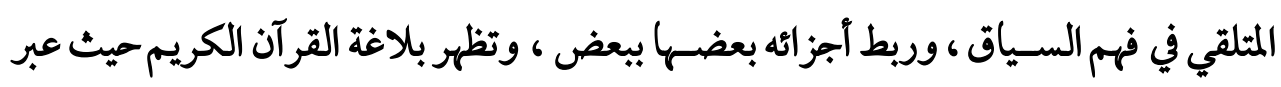

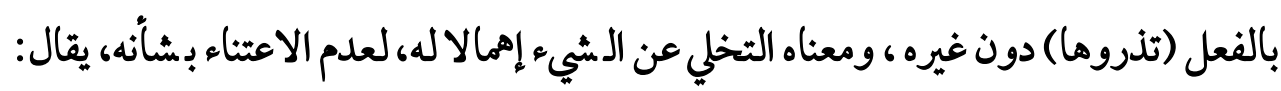

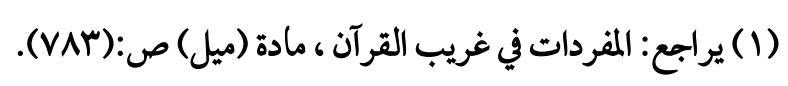

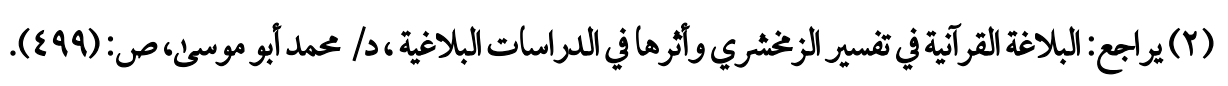


فلان يذر الثي_ء، أي: يقذفه لقلة اعتداده به(1)، ومهنا جاء دقيقا في موقعه حيث وضـح لنا من

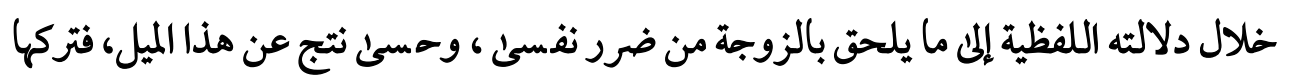

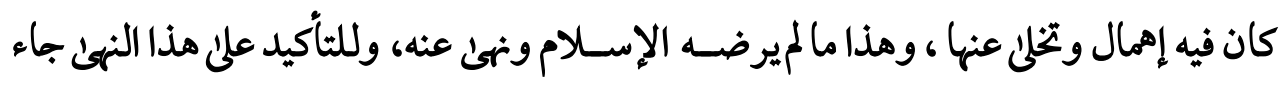

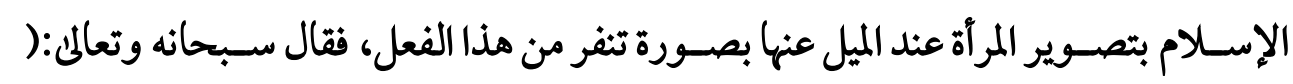

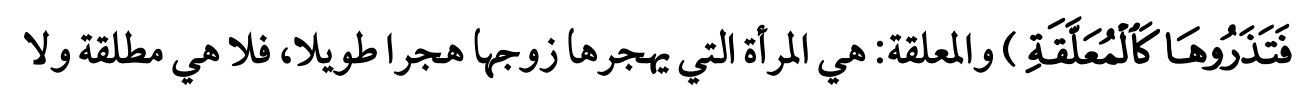

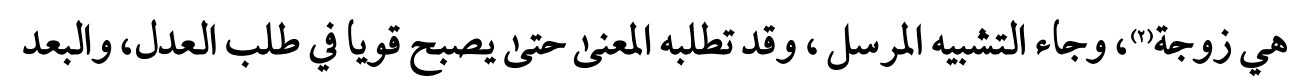

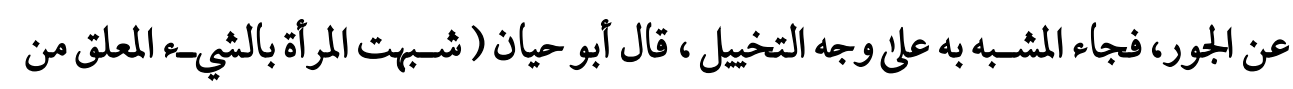

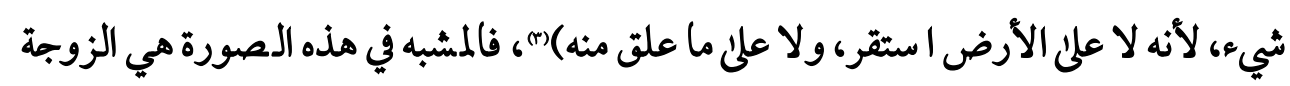

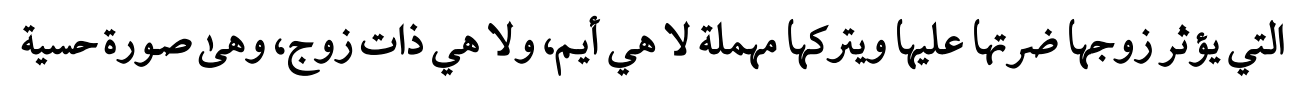
منتشرة في كثير من المجتمعات، والمشبه به صورة لإنسانة معلقة تتأرجح في المم لا تجد شيئا

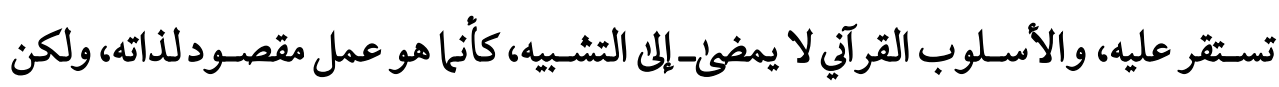

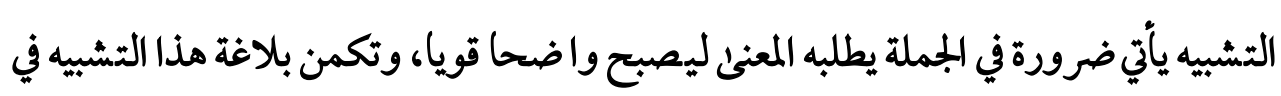

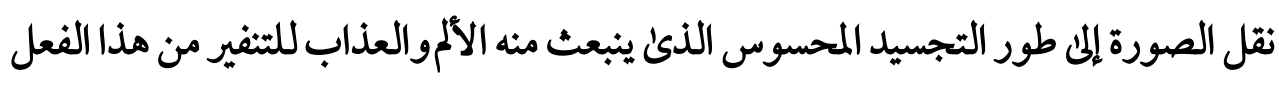

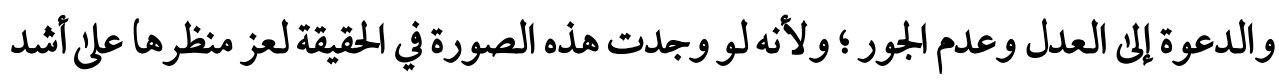

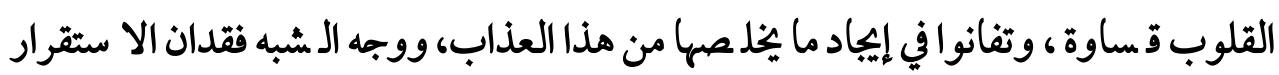

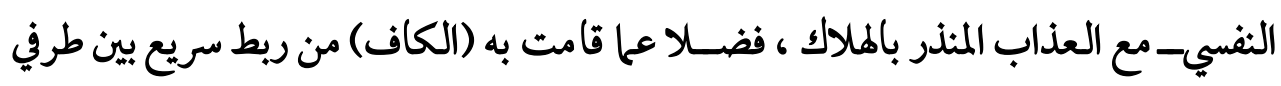

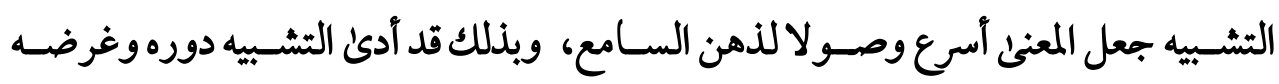

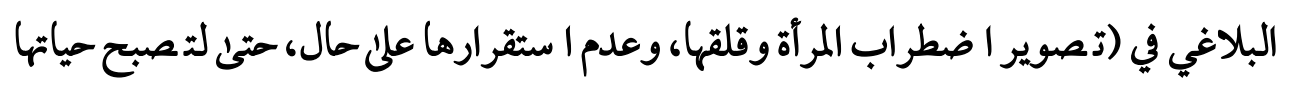

(1) يراجع: المفردات في غريب القرآن ، مادة (وذر) ص:(YTY).

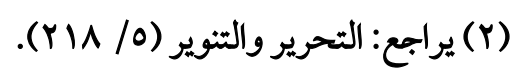

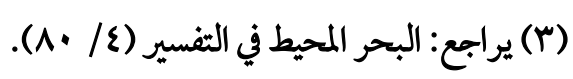


مليئة بالتعب والعناء)(")، وتنبيه الزوج علئ هذا الظلم الواقع علئ الزوجة ونهيه عنه، و قد أ ضفي التشبيه صورة حية حيث صور الزوجة بالمعلق الذئ لا يملك لنفسه قراراً ثابتاً ، ولا يستطيع الحلاص منه فلا هي زوجة، ولا هي مطلقة، وقرن هذا المشهد المروع بهذا المتاف المؤثر

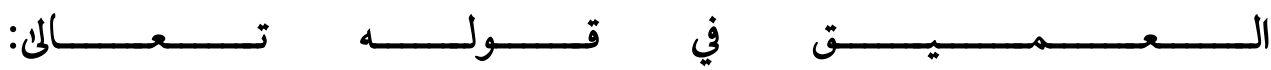

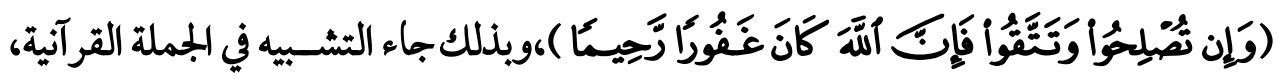
ليعطى الفكرة في صــورة واضـحة مؤثرة، وبهذه الصــورة الحية الناطقة ظهرت بلاغة القرآن

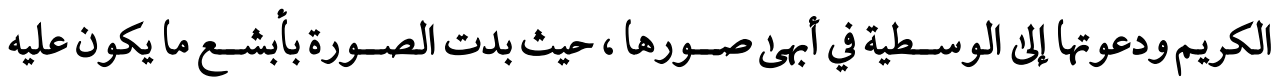

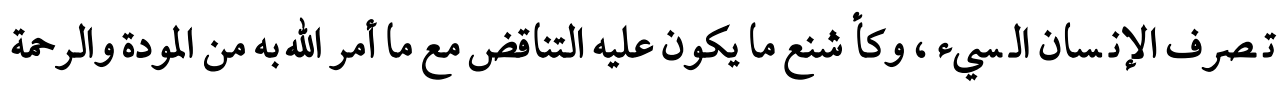

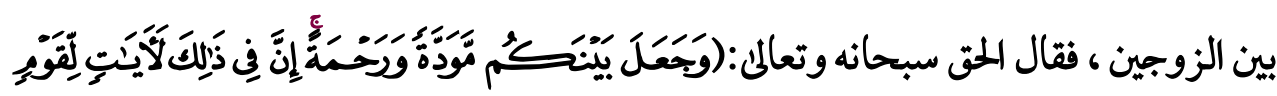

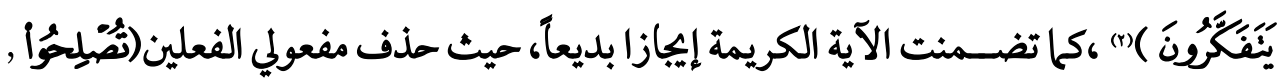
وَتَتَّقُواً) والغرض من هذا الإيجاز هو إنبات معنى الفعلين وصرف الاهتحام إليها، من خلال

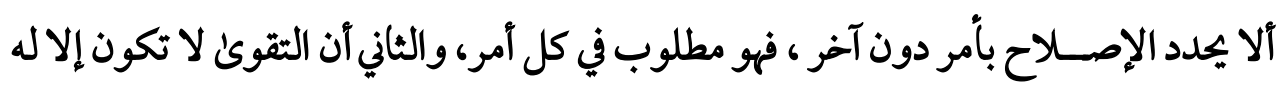

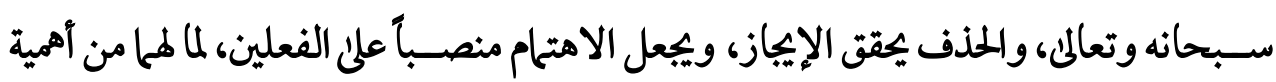
عظمئ في حياة المسلم، وبناء أسرة سعيدة.

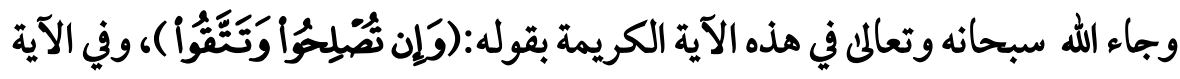
السـابقة بقوله:( وإن تحســوا وتتقوا) والجواب والله أعلم: أن الآية الأولى فيا بين المرآة

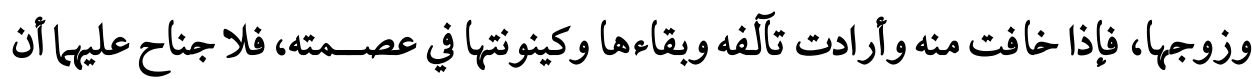
تعطى شيئاً من نفسها وتترك بعض حقها كأن تؤثر ضرتها في القسمة ، أو تترك هي حظها كاركا

$$
\begin{aligned}
& \text { (1) يراجع: من بلاغة القرآن ص: (1OY) ). }
\end{aligned}
$$

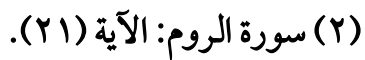


فعلت سودة (رضى اللهعنها)، أو تهب له من حالما لا جناح عليها في هذا ، ولا على زوجها في قبول ذلك منها، وإن كان الطبع يأبئ من إسقاط حق أو تنقصه لما جبلت عليه النفوس، وإليه إليه

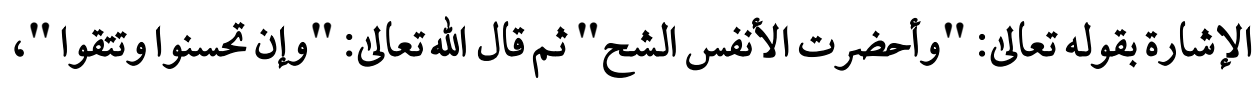

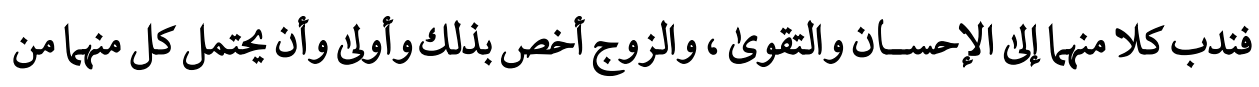

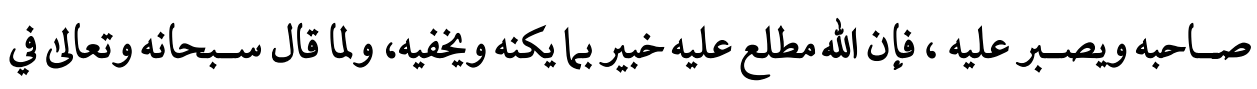

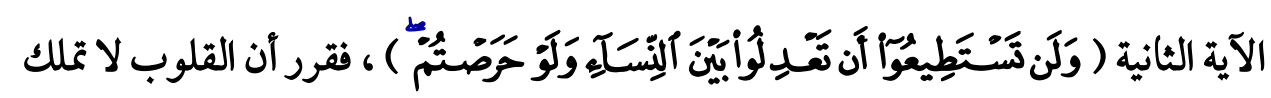

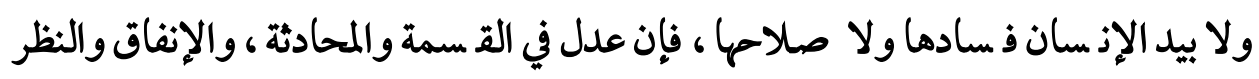

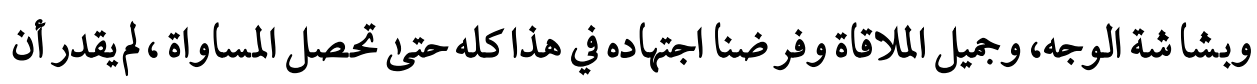
يميل بقلبه إلى كلهن علئ حال سواء: "فلا تميلوا كل الميل "بل علني الإنسان أن ييتهد ثم جاء

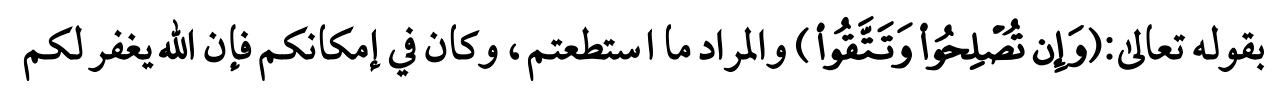

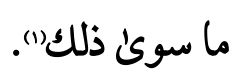

وقدختمت كل آية با يناسبها ، ومساق الآية الكريمة التي بين أيدينا تستدعلى آن تكون

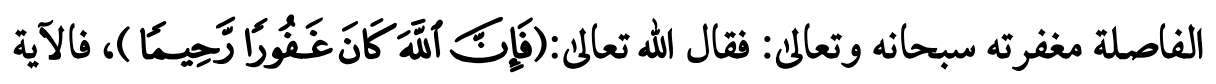

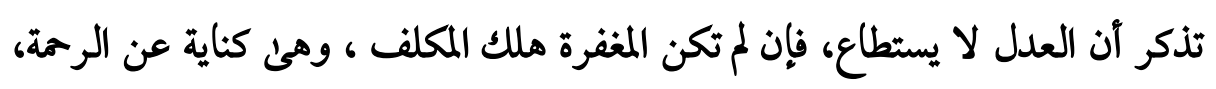

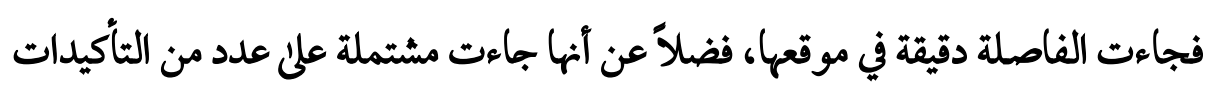

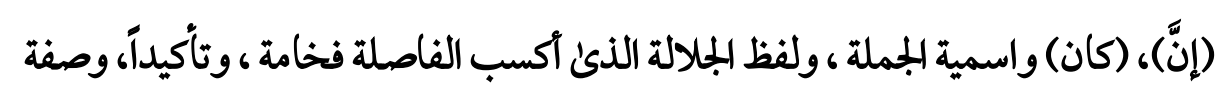
المبالغة التي أكدت علئ رمته سبحانه وتعالم، فهو سبحانه وتعالثى واسع المغفرة لمن لم لم

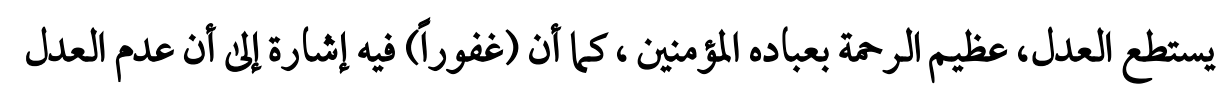
والميل فيه ظلم يقتضئ التوبة من العبد ، وقدم وصف المغفرة في الآية على الرحمة؛ لآن درء 
المفاسد مقدم علإ جلب المصالح") ، وهذا يشير إلى عظمة الإسلام ، وعدله في تقويم الفرد، مما يساعد علني إقامة بجتمع سليم قائم على العدل والوسطية. وبعد هذه الآيات السابقة التي عالج فيها الإسلام الشقاق بين الزوجين متبعاً فيها منهج

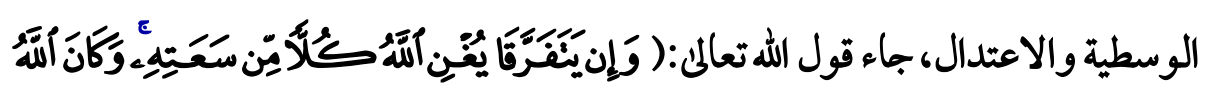

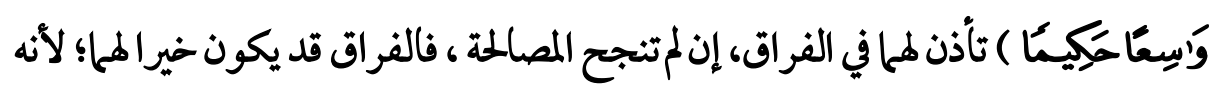
خير من سوء المعاثرة، فاستهلت الآية الكريمة بأداة الثرط (إن) التي تستخدم في الأمر غير المقطوع به، ويخالطه الشك(r)، ووقوع الطلاق بعد هذا العلاج اللحكيم الذئ قررته الآيات القرآنية السابقة أمر محتمل غير مقطوع به ، فمن اتبع شرع الله تعالى في علاج هذا

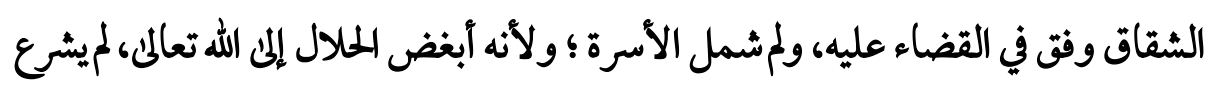
إلا إذا دعت إليه اللحاجة النفسية ، وهذه البمملة معطوفة على قوله تعلان:(فلا جناح عليها) أن يصلحا)، أي : إن لم يجد الصلح ، وتعذر قيام المودة والمحبة بينها، فالفرقة أفضل لهلا، وقوله (يتفرقا) كناية عن الطلاق ، وقد أسند الفعل إلى الزوج ، والزوجة لا لأحدهما؛ لآن التفرق بالطلاق نتيجة تفرق القلوب ، وعدم حرص أحد منها على استرضاء الآخر

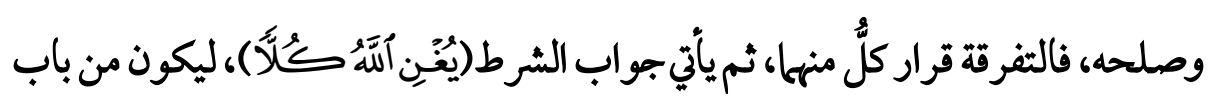
تسلية الله تعالى للزوجين حتى لا ييأس كلّ منها بعد هذه الفرقة، ويأمل فيا عنده سبحانه وتعالى، فهو الواسع في فضله ورحته ، فقد يسخر للمرآة رجلا خيرا منه، ويسخر للزوج امرأة خيرا منها ، ومن بلاغة القرآن الكريم انتقاء الفعل(يغنى) حيث الإجزاء، والنفع ،

(1) يراجع: ملاك التأويل القاطع بذوي الإلحاد والتعطيل في توجيه المتشابه اللفظ من آي التنزيل، لأمد بن إبراهيم الثقفي الغرناطي، وضع حواشيه: عبد الغني محمد علي الفاسي ، دار الكتب العلمية، بيروت،

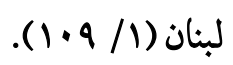

$$
\begin{aligned}
& \text { (Y) يراجع:الإيضاح ص:(oV). }
\end{aligned}
$$


والاكتفاء ، وإنباع الماجة ، والغنى يكون بالمال وغيره من القوة والمعونة") فعبر بهذه المادة

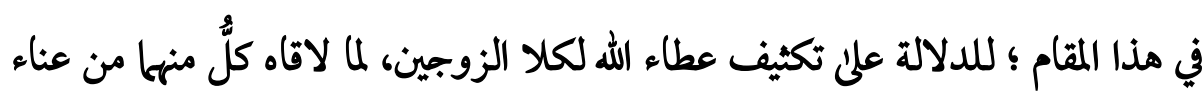
بسبب هذه الفرقة ، فجاءت كلمة (سَعَتِِّه)، لتعبر عن سعة قدرته وعلمه ورمته

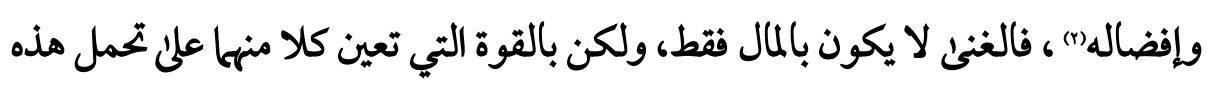

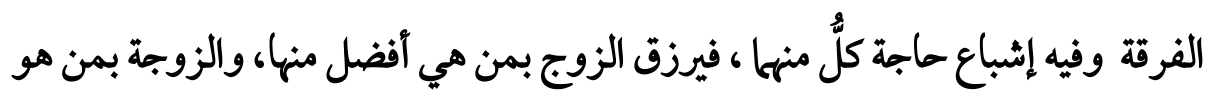

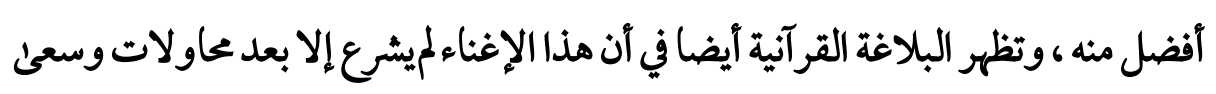

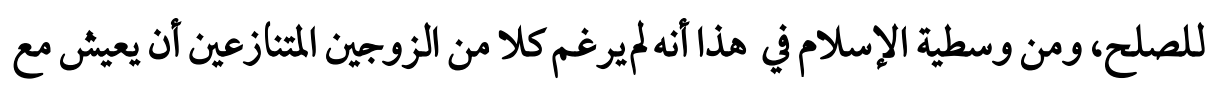

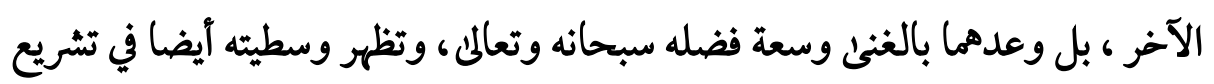
الطلاق ، حيث تظهر حكمته جلية واضحة في هذه المالة، من خلال مراعاة الجانب الشعوري للأبناء، والمفاظ عليه لينشأوا نشأة سوية بعيدة عما يؤثر علني أخلاقهم ، فإِنه

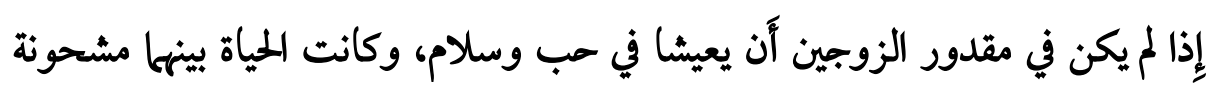
بالمتاعب والمصاعب، فإِن العاقبة ستكون سيئة بالنسبة لمجا، ولأبنائها .

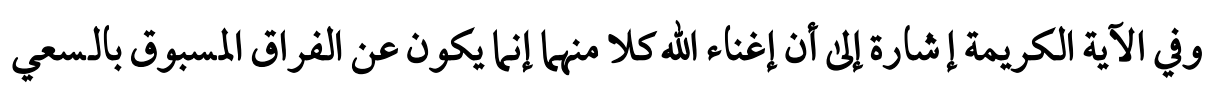

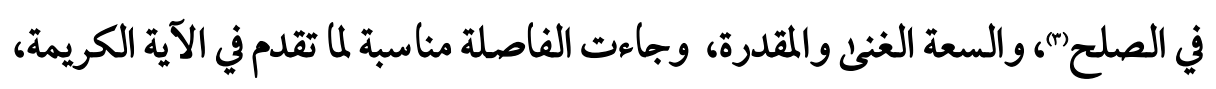

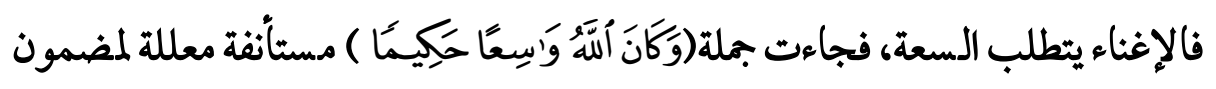

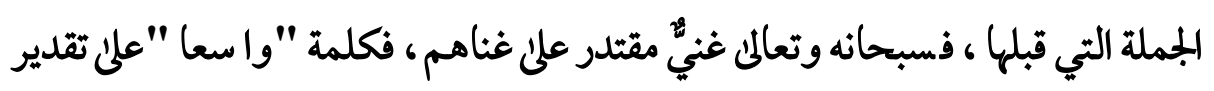

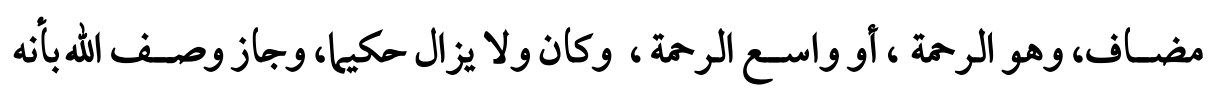

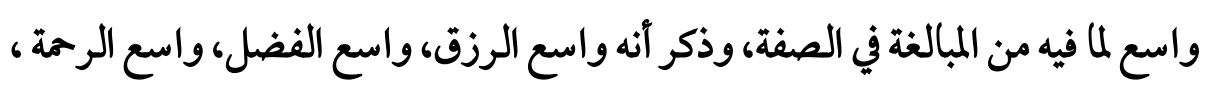

(1) يراجع: الفروق اللغوية للعسكري، ص:(IVO) ).

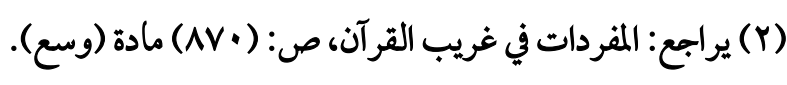

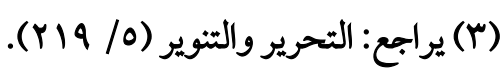


وواسع القدرة ، ولو ذكر علئ الأصل لاقتصر علنى واحد منها ، وإذا أطلق ذهب الحنيال إلى إلى

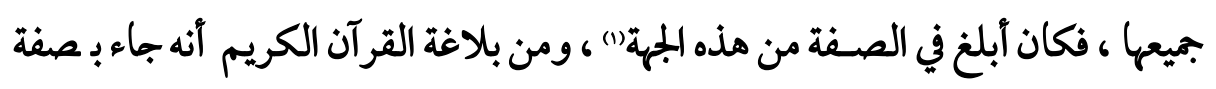

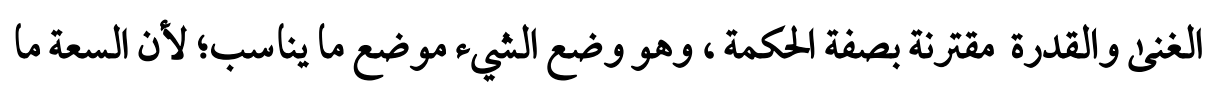

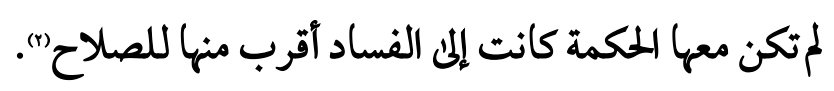
$\square$

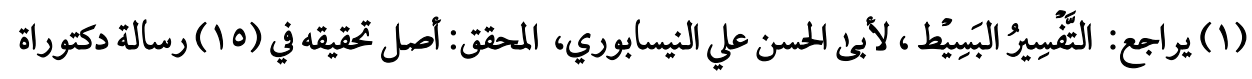

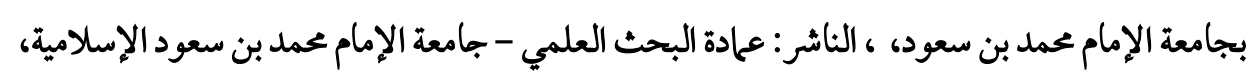

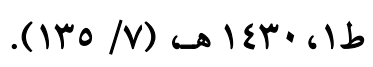

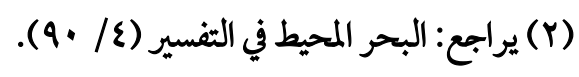




\section{الغاثة}

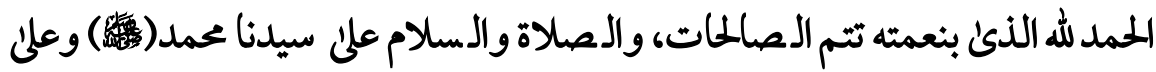

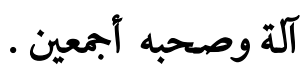

فتلك الدراسـة كانت محاولة للكثــف عن بعض الخصـائص البلاغية ، وجماليات الآيات القرآنية التي عالجت الشقاق بين الزوجين ، والتي أظهرت وسطية الإسلام ، ونظرته

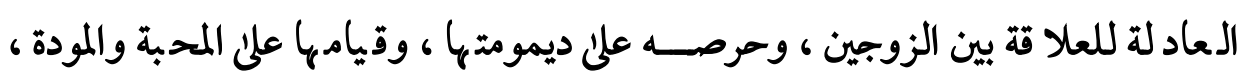
وا ستقامتها دون ذشوز، وفي ختام هذا البحث أذكر بعض التتائج التي تو صلت إليها لعلها تكون ذات قيمة، وقدجاءت الآيات الكريمة مشــملة علئ عدد من الأسـاليب البلاغية ، والتي كان لها دور بارز في عرض العلاج في صورة واضحة جلية ومنها:

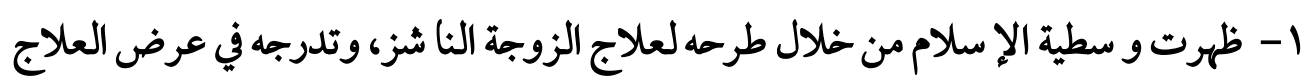

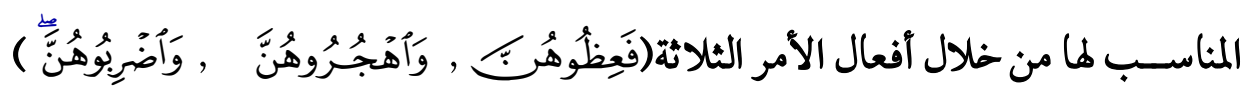
حيث جاء الأمر الأول يحمل معنى النصح ، والثاني والثالث يممل معنى الإباحة.

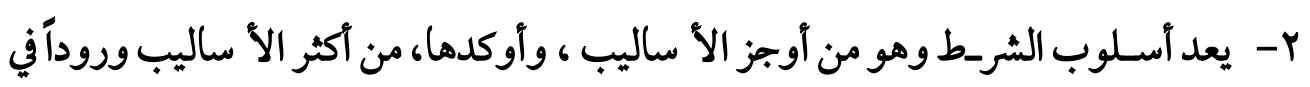

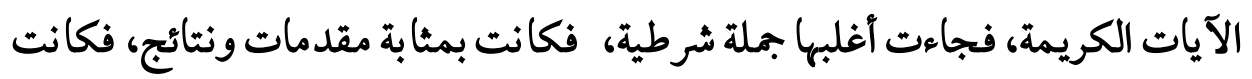

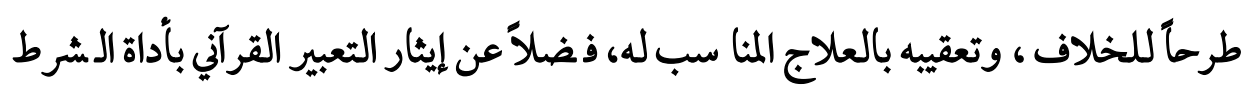
(إن) دون (إذا) ، وهنا تظهر و سطية الإ سلام في التعامل مع النفس البشرية ، فدينتا اللحنيف

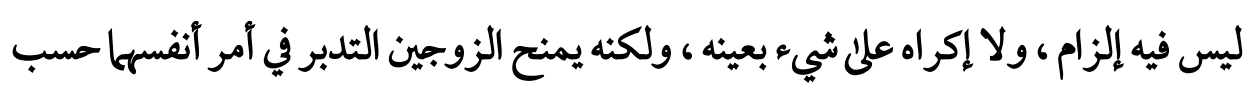
ما يرى كل واحد منها الأصلح له.

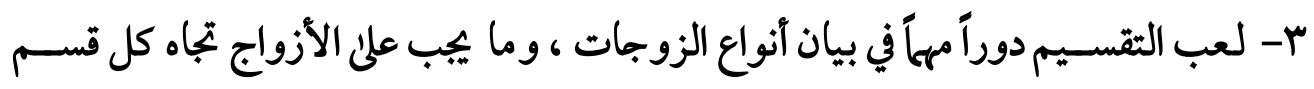
بشروط وضوابط حددها الإسلام يجفظ للمرأة كرامتها وعزتها. ع- نجد أن الأصوات في لغة القرآن الكريمو صلت إلماريط حد الإعجاز ، وأن الحروف عبارة عن 
ريشات مصورة للمعاني، وترسم الكلمة حركةً وصوتاً ليتسق مع المعنى.

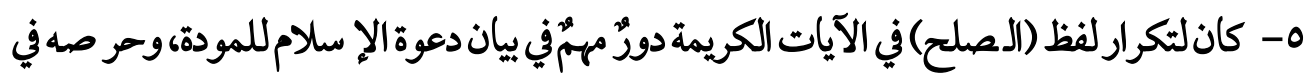
المحافظة على الأسرة وترابطها بحايحق الأمن للفردوالمجتمع ، فنكراره لفت الانتباه إليه، وتسـليط الضوء عليه ، وكأن الصلح هو المراد الذي ترمئ إليه الآيات الكريمة.

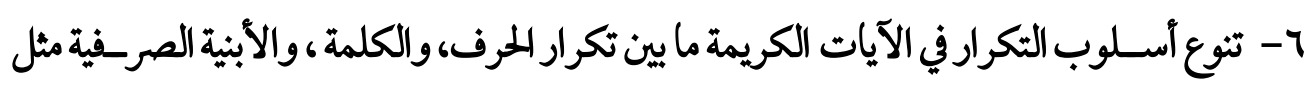
صيغ المبالغة ، واسم الفاعل ، وفعل الأمر، والتي كانت جميعها معبرة عن المعنى أدق تعبير.

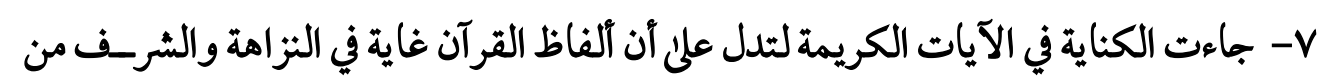
خلال استخدام أسلوب الكناية، عا يكون بين الزوج وزوجته ، والابتعادعن الألفاظ التي لإني تخدش الحياء. 1- آن ألفاظ القرآن فضــلاًَعن دقة اختيارها ، وروعتها في أنفسهها، تأتئ ملائمة للمقام الذي

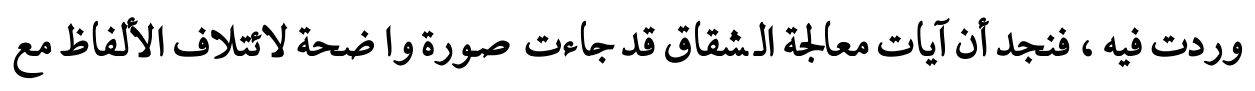
المعاني فكان التلاؤم والانسـجام، لذا جاءت ألفاظها هادئة تتناسـبـ مع تدعو إليه من استقرار وسكينة بين الزوجين.

9- اشــملت الآيات الكريمة التي تتحدث عن نثـــوز الزوج علئ صـورة فنية قائمة علي التشـبيه

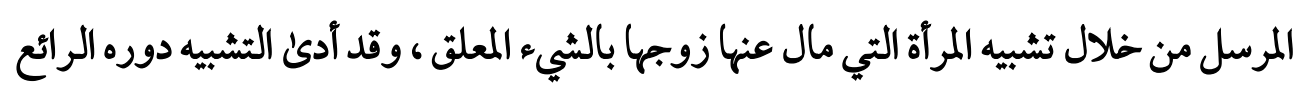

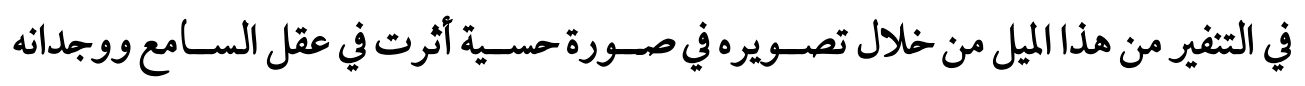

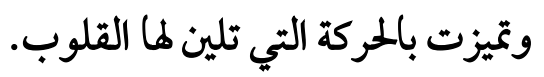
التوصيات وفي النهاية أوصحل نفسى وكل باحث في البلاغة العربية أن يستقى أصول هذا العلم من نبعه الصافي العذب (القرآن الكريم) . وأوصئ الآزواج والزوجات بالتم سك بكتاب الله تعالم ، وما فيه من تشريعات تخص الحياة الزوجية ، لو تمسكك بها كل زوج ، وزوجة لما كان هناك نشـوز ولا شـقاق، وتربئ الأبناء في جو من الألفة والمودة. 
وم سك المتتام ، فالبحث ، وما ا شتمل عليه من مباحث ما هو إلا عمل بـشرئ ، فالكمال لله

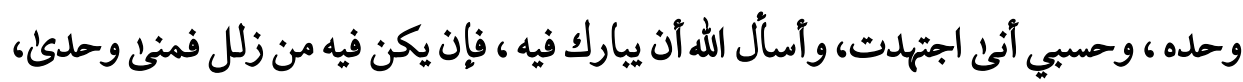

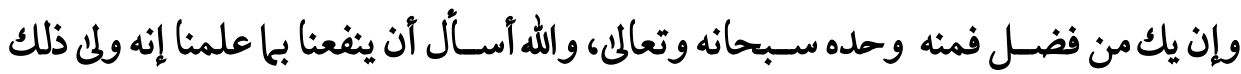
والقادر عليه، والحمد لله رب العالمين . 


\section{خامساً ؛ شهرب المصادروالمراجع}

أولاً: القرآن الكريم

ثانياً: المصادروالمراجع. ألمران.

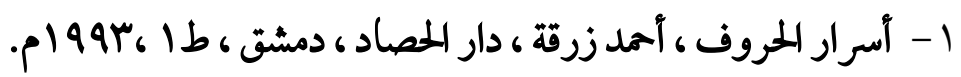

r - إعجاز القرآن ، لأبى بكر الباقلاني محمد بن الطيب ، تحقيق: السيد أحمدصقر ، دار

المعارف - مصر ك، ط0، 1994 ام.

r- إعجاز القرآن والبلاغة النبوية مصطفي صادق الرافعي ،طع - مطبعة الاستقامة

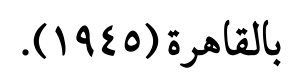

ع - الإعجاز والإيجاز لعبد الملك بن محمد أبو منصور الثعالبي ، مكتبة القرآن - القاهرة.

ه- آنوار التنزيل وأسرار التأويل ، ، ناصر الدين البيضاوي ، تحقيق: محمد عبد الرحمن

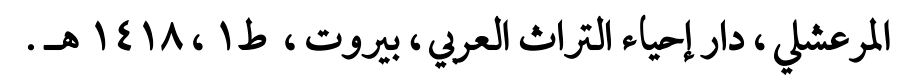

7- الإيضاح في علوم البلاغة لجلال الدين محمد بن عبد الرحمن القزوينى ، تحقيق/ محمد عبد المنعم خفاجلى ، ط ، دار الجيل ، بيروت.

-V

دار الفكر - بيروت، ط: • ب أ هـ.

^- بدائع الفوائد ، لمحمد بن أبي بكر بن أيوب بن سعد شمس الدين ابن قيم الجوزية، دار الكتاب العربي، بيروت، لبنان.

9- البرهان في علوم القرآن ، لأبئ عبد الله بدر الدين الزركثي تحقيق: محمد آبو الفضل

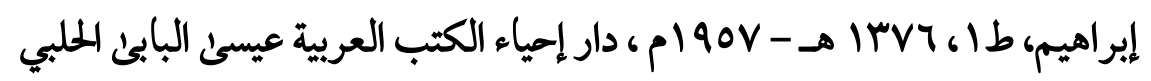

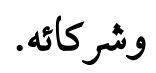

• 1 - بغية الإيضاح لتلخيص المفتاح في علوم البلاغة عبد المتعال الصعيدي ، الناشر:

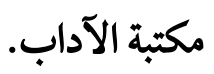


1 ا 1 - البلاغة العربية لعبد الرحمن بن حسن حَبَّكَة الميداني الدمشقي ، دار القلم، دمشق،

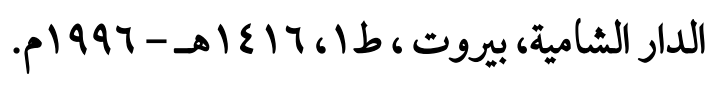

r ا - البلاغة القرآنية في تفسير الزمخشري وأثرها في الدراسات البلاغية ، دا ما محمد أبو

$$
\text { موسىى، دار الفكر العربي، القاهرة. }
$$

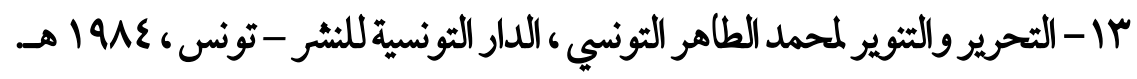

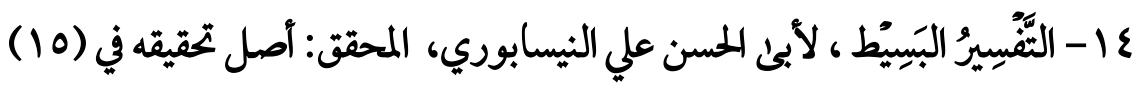
رسالة دكتوراه بجامعة الإمام محمد بن سعود، ثم قامت لجنة علمية من البامعة بسبكه

وتنسيقه، الناشر: عهادة البحث العلمي - جامعة الإمام محمد بن سعود الإسلامية.

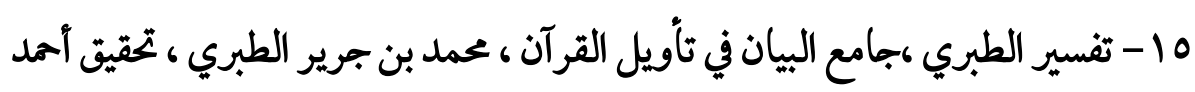

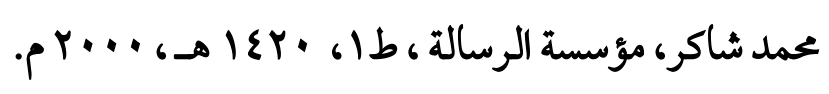

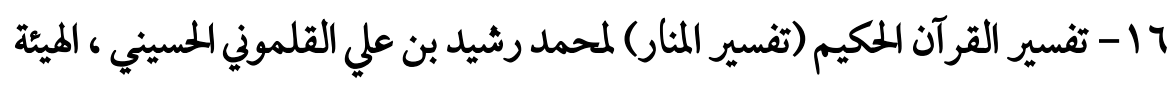

$$
\text { المصرية العامة للكتاب ، -199 ام. }
$$

IV - الثفسير الكبير، لأبئ عبد اللهممد الرازي ، دار إحياء التراث العربي، بيروت،

$$
\text { طץ- }
$$

11 - تفسير الماوردي = النكت والعيون ، لأبئ المسن علي بن محمد، الشهير بالماوردي، تحقيق: السيد ابن عبد المقصود بن عبد الرحيم، دار الكتب العلمية ، بيروت ،لبنان.

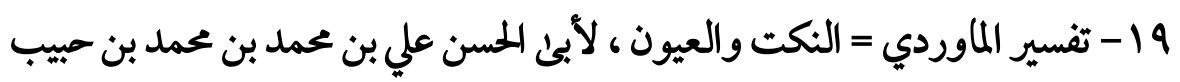

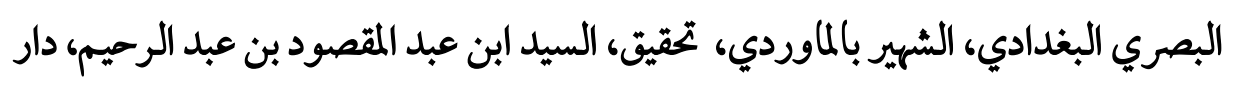

$$
\text { الكتب العلمية - بيروت ، لبنان. }
$$

• ب - تفسير المراغلى ، لأمد بن مصطفي المراغي ، مطبعة مصطفي البابئ الحلبي

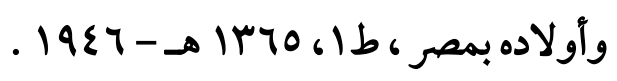


الب - التفسير المنير في العقيدة والشريعة والمنهج ، للدكتور: وهبة بن مصطفي الزحيلي،

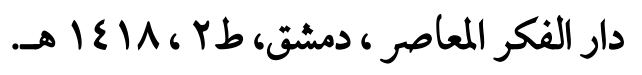

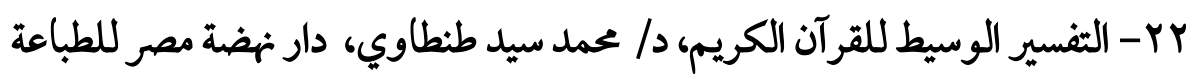

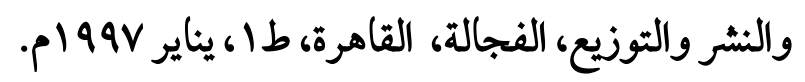

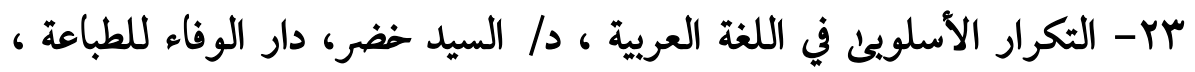

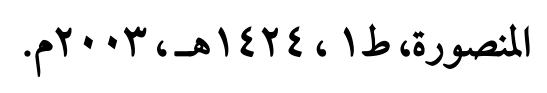

ع Y - تنوير المقباس من تفسير ابن عباس ، لعبد اللهبن عباس - رضي الله عنها ، جمعه: مجد الدين أبو طاهر محمد بن يعقوب الفيروز أبادنا، دار الكتب العلمية - لبنان.

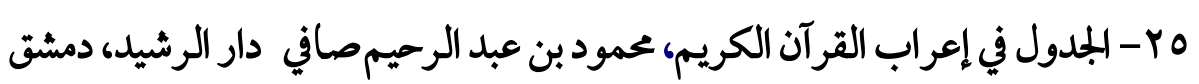
- مؤسسة الإيهان، بيروت. - مان. جr - جواهر البلاغة في المعاني والبيان والبديع لأممد بن إبراهيم بن مصطفي الهاشمي ت: د. يوسف الصميلي، المكتبة العصرية ، بيروت.

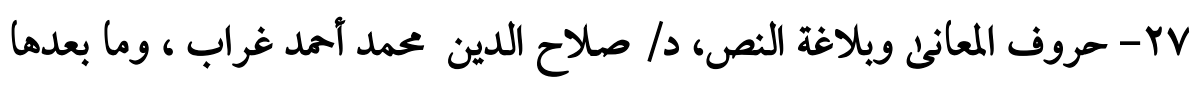
بحث بلاغلى مقدم إلى مؤتمر كلية اللغة العربية بالزقازيق ، 9 ×. بrم.

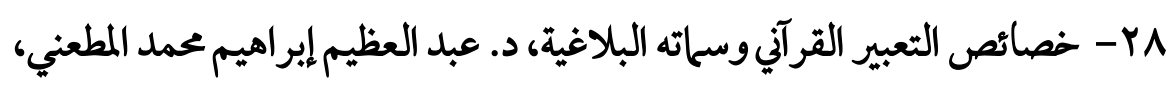

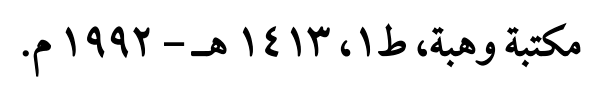

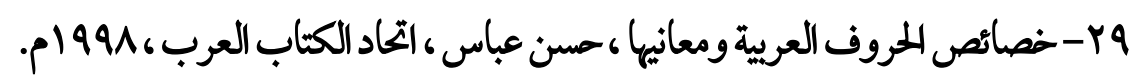

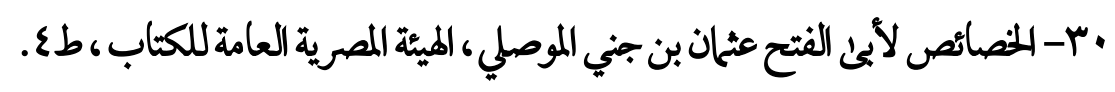

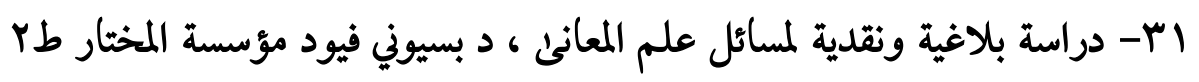

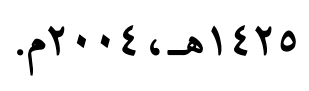

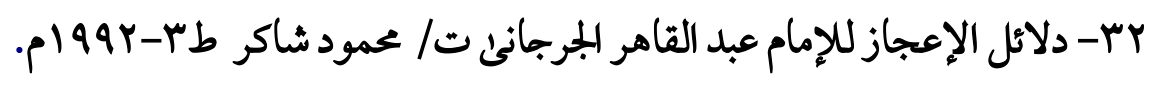


بـ- روائع البيان تفسير آيات الأمكام ، محمد علي الصابوني، مكتبة الغزالي - دمشق،

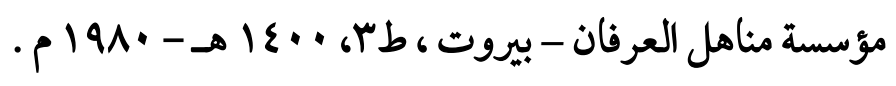

ع ع-روح اليان، لإسماعيل حقي الإستانبولي المنفي المولى أبو الفداء ، دار الفكر - بيروت.

مب- روح المعاني في تفسير القرآن العظيم والسبع المثاني لشهاب الدين الألوسي ، تحقيق:

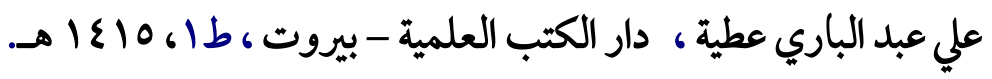

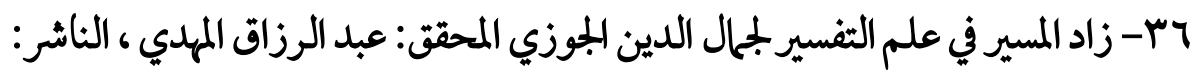

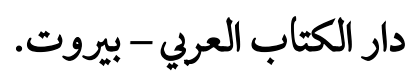

rrV الحميد، المكتبة العصرية،صيدا ،بيروت.

^r- شروح التلخيص، طع ، دار المادئ ، بيروت ، لبنان، مواهب الفتاح ، يعقوب

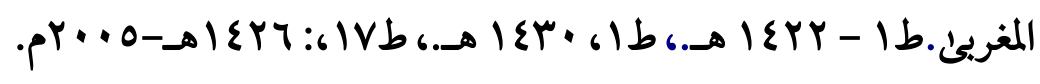

9 ا-صحيح مسلم لمسلم بن الحجاج النيسابوري، تمقيق: محمد فؤاد عبد الباقي ، دار

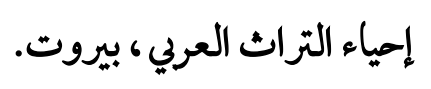

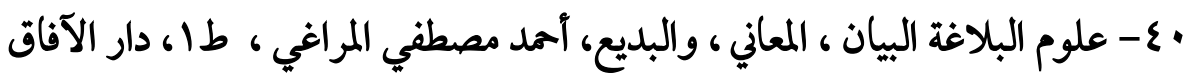

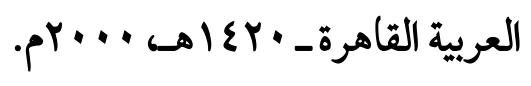

اع- فتوح الغيب في الكشف عن قناع الريب (حاشية الطيبي على الكشاف)لشرف الدين المسين بن عبد الله الطيبي ، تحقيق: إياد محمد الغوج.

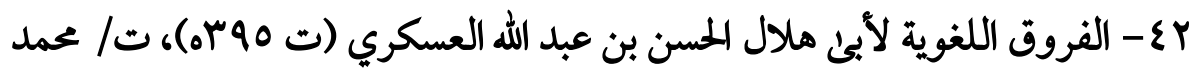
إبراهيم سليم، دار القلم والثقافة للنشر والتوزيع ، القاهرة ، مصر. القسم الدراسي: د. جميل

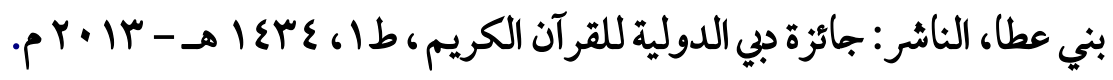
بع - الكثاف عن حقائق غوامض التنزيل،ابو القاسم محمود، الزيخشري جار الله ، دار

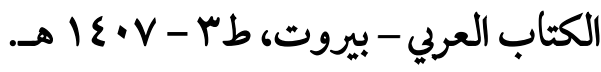


ع ع - لسان العرب لابن منظور، طب ،ع إع ا هـ ، دار صادر ، بيروت. 0 ع - المحكم والمحيط الأعظم، لأبيى الحسن علي بن إسهاعيل بن سيده المرسي ، ت عبد

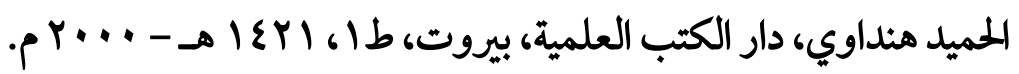
ج ₹ - معانئ القرآن لأبى الحسن البصري، المعروف بالأخفش تحقيق: الدكتورة هدى

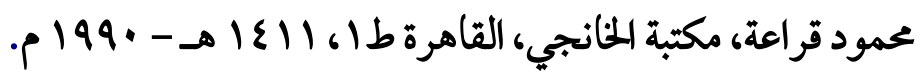
VV - معجم مقاييس اللغة ، أحمد بن فارس ، تحقيق: عبد السلام محمد هارون، دار

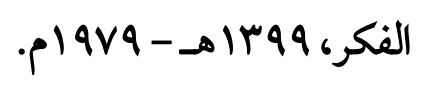

^ع - مفتاح العلوم ، لأبى يعقوب يوسف بن أبي بكر السكاكي ، دار الكتب العلمية،

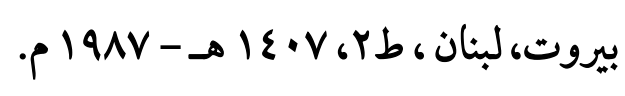

9 - المفردات في غريب القرآن لأبى القاسم المعروف بالراغب الأصفهانى، تحقيق:صفوان عدنان الداودي ، الناشر: دار القلم، الدار الشامية - دمشق بيروت ، طا - r ع ع ا هـ. • م- ملاك التأويل القاطع بذوي الإلحاد والتعطيل في توجيه المتشابه اللفظ من آي التنزيل، لأحمد بن إبراهيم الثقفي الغرناطي، وضع حواشيه: عبد الغني محمد علي الفاسي، دار الكتب العلمية، بيروت ،لبنان.

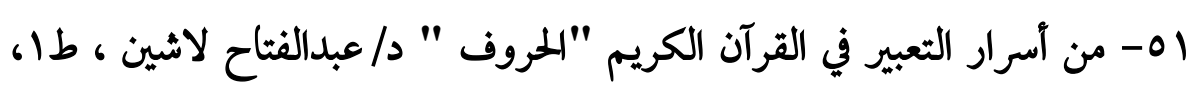

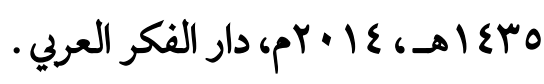
ro - من اللخصائص البلاغية واللغوية في أسلوب الحديث النبوئ الشريف د/ فتحية فرج

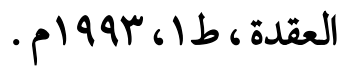

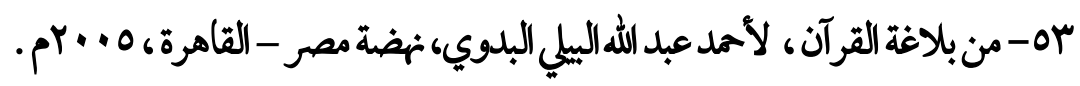
ع - من جمال النظم القرآني في سورة إبراهيم دراسة تحليلية بلاغية، د، صلاح الدين

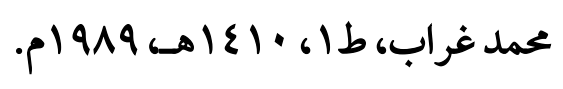
هـ - من روائع القرآن ، د / محمّد سَعيد رَمضان البوطي ، مؤسسة الرسالة ، بيروت ، 


$$
\text { . 1999-ه1\&r. }
$$



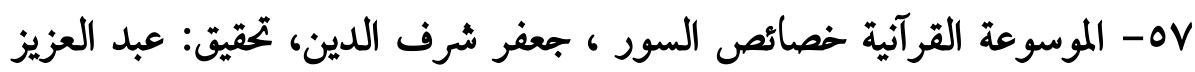

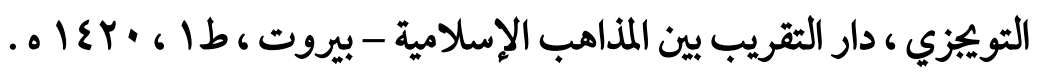

10 - النحو الوافي لعباس حسن ط (10) ، دار المعارف.

هـ- نظم الدرر في تناسب الآيات والسور، لإبراهيم بن عمر البقاعي ، دار الكتاب

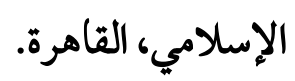

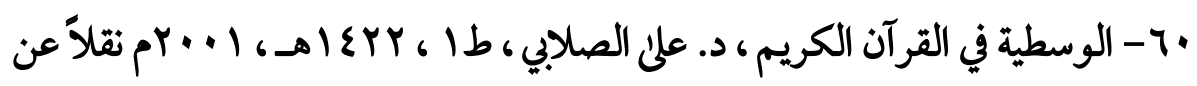
بحث رسالة ماجستير بعنوان الوسطية في الإسلام ، مقدم من الباحث فريد عبدالقادر ،

جامعة محمد بن سعود. 
- Yrs. - 